\title{
Review
}

\section{You Don't Learn That in School: An Updated Practical Guide to Carbon Quantum Dots}

\author{
Helena B. A. Sousa ${ }^{+}\left(\mathbb{D}\right.$, Catarina S. M. Martins ${ }^{+}(\mathbb{D}$ and João A. V. Prior *(i) \\ LAQV, REQUIMTE, Laboratory of Applied Chemistry, Department of Chemical Sciences, Faculty of Pharmacy, \\ University of Porto, Rua de Jorge Viterbo Ferreira n. 228, 4050-313 Porto, Portugal; hbffup@gmail.com (H.B.A.S.); \\ catsofiamartins@gmail.com (C.S.M.M.) \\ * Correspondence: joaoavp@ff.up.pt; Tel.: +351-2204-28670 \\ + Authors had equal contribution to this work.
}

Citation: Sousa, H.B.A.; Martins, C.S.M.; Prior, J.A.V. You Don't Learn That in School: An Updated Practical Guide to Carbon Quantum Dots. Nanomaterials 2021, 11, 611. https:// doi.org/10.3390/nano11030611

Academic Editor: Gabriele Giancane

Received: 25 January 2021

Accepted: 22 February 2021

Published: 1 March 2021

Publisher's Note: MDPI stays neutral with regard to jurisdictional claims in published maps and institutional affiliations.

Copyright: (C) 2021 by the authors. Licensee MDPI, Basel, Switzerland. This article is an open access article distributed under the terms and conditions of the Creative Commons Attribution (CC BY) license (https:/ / creativecommons.org/licenses/by/ $4.0 /)$.

\begin{abstract}
Carbon quantum dots (CQDs) have started to emerge as candidates for application in cell imaging, biosensing, and targeted drug delivery, amongst other research fields, due to their unique properties. Those applications are possible as the CQDs exhibit tunable fluorescence, biocompatibility, and a versatile surface. This review aims to summarize the recent development in the field of CQDs research, namely the latest synthesis progress concerning materials/methods, surface modifications, characterization methods, and purification techniques. Furthermore, this work will systematically explore the several applications CQDs have been subjected to, such as bioimaging, fluorescence sensing, and cancer/gene therapy. Finally, we will briefly discuss in the concluding section the present and future challenges, as well as future perspectives and views regarding the emerging paradigm that is the CQDs research field.
\end{abstract}

Keywords: carbon quantum dots; synthesis; surface modifications; separation methods; chemosensors; biosensors

\section{Introduction}

Carbon quantum dots (CQDs) are a type of zero-dimensional carbonaceous fluorescent nanomaterial, generally smaller than $10 \mathrm{~nm}$. Structurally, CQDs are clusters of carbon atoms with a substantial percentage of oxygen and hydrogen atoms at their surface, resulting in low toxicity and excellent biocompatibility that make CQDs promising fluorescent platforms for numerous applications, particularly when compared with conventional metal quantum dots [1-3]. CQDs were serendipitously discovered in 2004 by $\mathrm{Xu}$ et al. during the processing of single-walled carbon nanotubes (SWCNT) through gel electrophoresis [4].

Presently, CQDs are often mistaken for their carbon-based counterparts, such as graphene quantum dots (GQDs) or carbon nanodots (CNDs), despite the strikingly dissimilar properties, as depicted in Table 1. Based in the systematic classification employed by Valcárcel et al. [3], CQDs correspond to crystalline spherical structures with quantum confinement composed mainly by a mixture of $\mathrm{sp}^{2}$ and $\mathrm{sp}^{3}$ carbons, and GQDs are composed by single nanosheets of $\mathrm{sp}^{2}$ carbons, whereas CNDs can be described as quasi-spherical amalgams of chiefly $\mathrm{sp}^{3}$ carbons in an amorphous structure that lacks quantum confinement. Additionally, the observation of CQDs via HRTEM reveals lattice fringes of $0.34 \mathrm{~nm}$ matching the (002) interlayer spacing of graphite, while GQDs present lattice fringes of $0.24 \mathrm{~nm}$ consistent with the (100) interlayer spacing of graphite $[5,6]$. Through the variation of the synthesis precursors and methods used during their production, it is possible to obtain these distinct types of carbonaceous nanomaterials.

Due to their structure, CQDs are known to possess important features that have, over the years, made them attractive for usage in photomediated applications. Amongst their many qualities, CQDs display tunable photoluminescence (PL), biocompatibility, broad emission range, high photostability, and they can behave either as electron donors or acceptors [6]. 
Table 1. Comparison of the different photoluminescence mechanisms and particular features of semiconductor quantum dots (SQDs) and carbon-based nanomaterials.

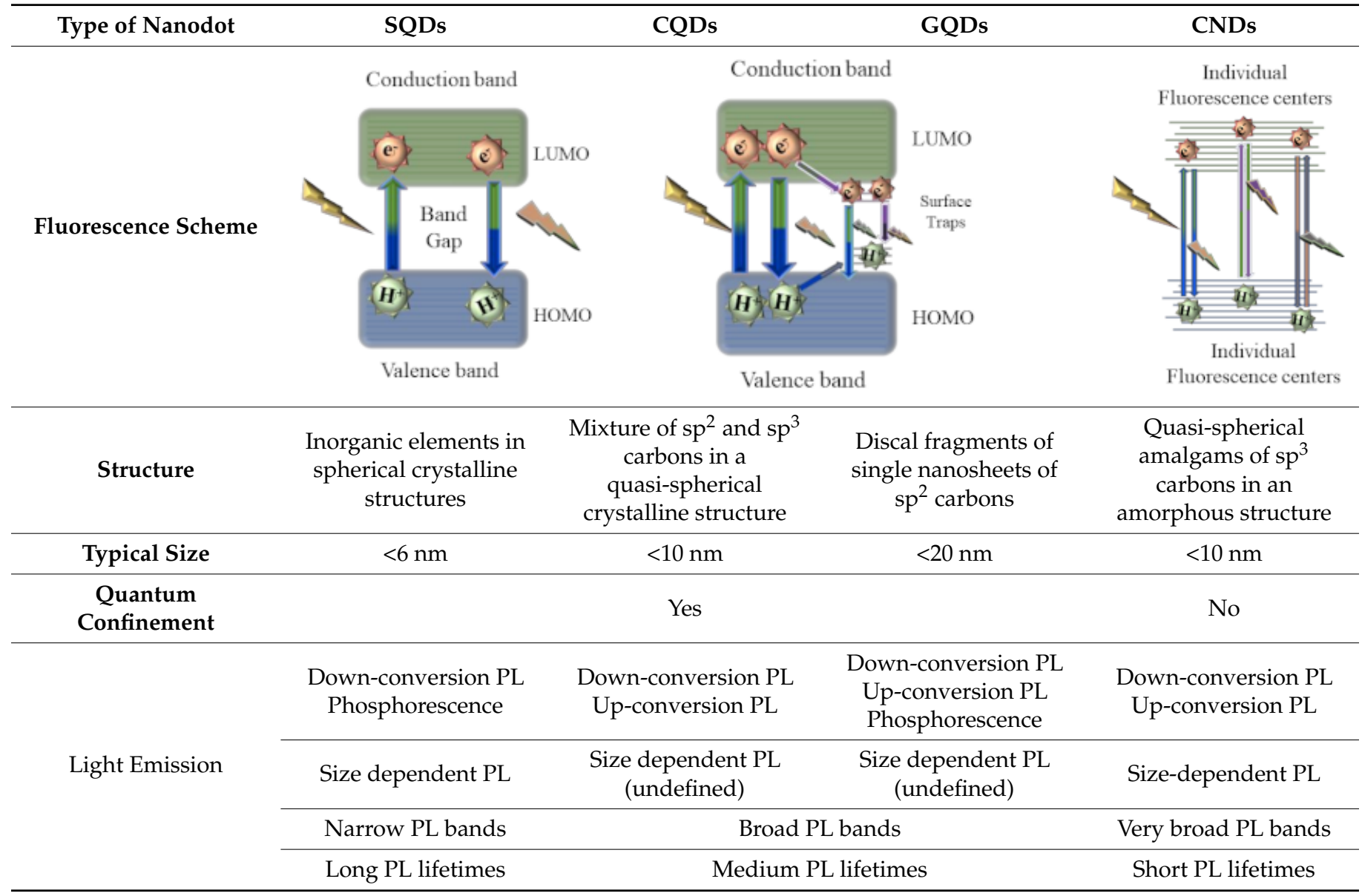

As for the fluorescence mechanism that grants CQDs with their unique optical properties, it is yet to be completely clarified. However, three possible mechanisms have been proposed: quantum confinement effect, surface defect states, and incorporation of fluorophores. Quantum confinement effect (QCE) is a phenomenon that occurs when CQDs display a size smaller than the exciton Bohr radius. The smaller the CQDs, the higher the band gap energy between the valence band and conduction band, which results in a blue-shift in CQDs photoluminescence. This causes a band gap transition in the ultravioletvisible region. As the optical properties of CQDs are directly linked to the $\pi$-electron state of the $\mathrm{sp}^{2}$ carbons, modifying the size of the conjugated $\pi$-domains will result in either a promotion or inhibition of the direct transition of conduction band electrons to the valence band, which is the process responsible for band gap fluorescence $[7,8]$. Other than quantum confinement effect, surface defect states have also been pointed out as a possible fluorescence mechanism. Surface defects correspond to a spheroidal area separate from CQDs' carbon core, mainly originated due to surface oxidation. By acting as capture centers for excitons, surface defects generally lead to a multicolor light emission, being responsible for excitation dependent behavior. Higher amounts of surface defects, corresponding to a greater degree of surface oxidation, generate a red-shift in the emission wavelength. Finally, the presence of fluorophores is also a common cause for CQDs fluorescence, especially in synthesis using smaller molecules as starting materials [7]. Due to being low molecular weight molecules, during the synthesis process they easily establish connections that may originate fluorophores with aromatic structures such as 1,2,3,5-tetrahydro-5-oxoimidazo [1,2-a]pyridine-7-carboxylic acid (IPCA) or 5-oxo-3,5-dihydro-2H-thiazolo [3,2-a] pyridine-3,7-dicarboxylic acid (TPDCA), both depicted in Figure 1. 


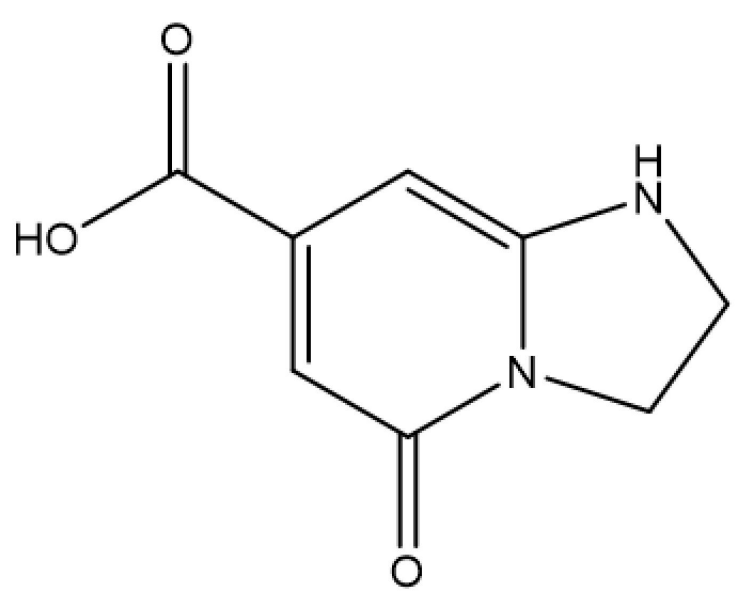

(a)

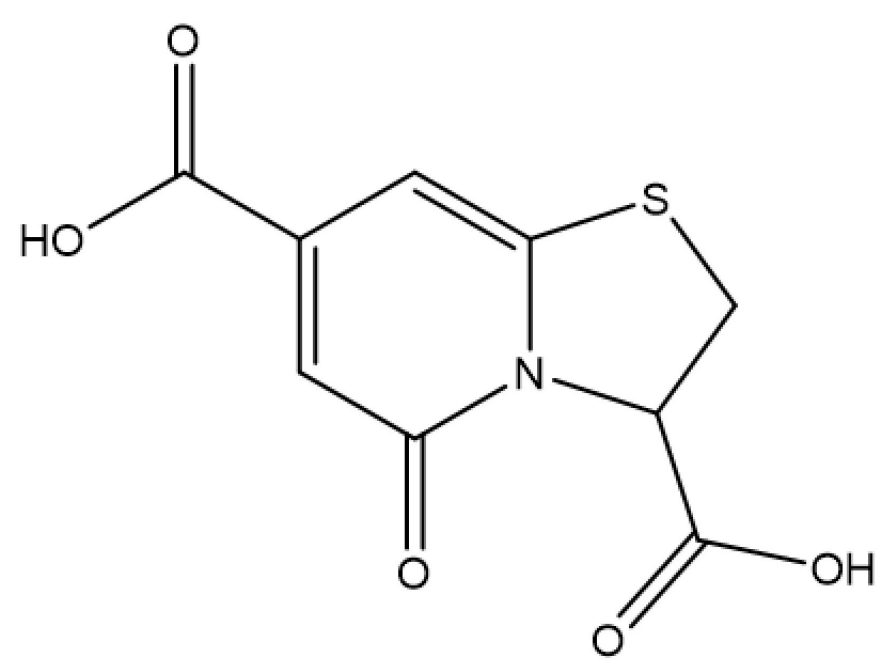

(b)

Figure 1. Chemical structures of IPCA (a) and TPDCA (b).

Due to recent developments in the purification area, there has been an increasingly clear relationship between the quantum yield of CQDs and the presence of these fluorophores both on the surface of CQDs and in solution. As they are water-soluble, a good purification method is important to guarantee that the determined quantum yield corresponds to CQDs and not to fluorophores.

Other than their exquisite optical properties, CQDs present higher chemical and physical stability and lower cost than conventional fluorescent nanoparticles, namely semiconductor quantum dots. Additionally, and of most importance, their outstanding resistance to photobleaching is a great advantage over the semiconductor quantum dots or organic dyes, since CQDs are much less susceptible to light exposure, especially when well dispersed. Furthermore, stabilizing CQDs in a polymer matrix can further contribute to preserving their characteristic fluorescence $[9,10]$. These properties coupled with good cell permeability, weak interactions with serum proteins, as well as immune system evasion, have made CQDs the ideal fluorescent nanosystem in applications that range from bioimaging, optoelectronics, energy conversion, and gene/drug delivery to their usage as antimicrobial agents or in chemical sensing [1,6,11-15]. Moreover, several works have focused specifically on the ecologically sustainable synthesis of CQDs, and as such, their applications in previously unexplored settings are expected to spread out even further in the impending future $[12,16,17]$ To efficiently tune the intrinsic optic and electron transfer properties of CQDs, specific synthesis strategies must be adopted to modulate their size and surface configuration, namely usage of distinct synthesis routes, surface passivation, and/or functionalization or heteroatom doping [15,18].

In the present review, a systematic and concise approach has been taken to survey the latest state of the art (between 2018 and 2020) of CQDs in terms of synthesis, concerning both the methodologies and the starting materials employed. Additionally, this work will emphasize the importance of adequate characterization and purification methods and their impact in the final quality of CQDs. Several surface modifications and heteroatom doping may be carried out to optimize CQDs properties to ensure their best performance in multiple applications, and as such, those modifications are likewise a feature in the present work. The diverse applications in which the CQDs are used will be explored with the aim of improving the current insights into the importance and potential of CQDs in fields as diverse as cell imaging, biosensing, or targeted drug delivery. Finally, a brief overview of the difficulties and challenges presented nowadays in CQDs synthesis and usage is provided, to explore possible future directions and perspectives in the field of CQDs research. 


\section{Synthesis Methods of CQDs}

Typically, the strategies of CQDs synthesis are organized in two main categories, top-down and bottom-up routes. While the top-down route requires rupturing or splitting more complex molecular structures into smaller ones through physical, chemical, or electrochemical methods, CQDs prepared by the bottom-up route are formed either by carbonization or pyrolysis of small organic precursors into nanosized particles. These organic molecules generally undertake four stages during the growth of CQDs, namely condensation, polymerization, carbonization, and passivation $[6,13,19]$. Commonly used top-down approaches include electrochemical oxidation (electrolysis), laser ablation, sonochemical synthesis, and arc-discharge methods, whereas bottom-up approaches usually employ microwave irradiation and hydrothermal/solvothermal treatment $[12,15,20]$. In this review, because of their widespread use, bottom-up approaches will be explored more thoroughly, namely the hydrothermal/solvothermal and microwave-assisted routes of synthesis. A brief examination of other CQDs synthesis methodologies reveal approaches based on electrochemistry, sonochemistry, and laser ablation. Additionally, a brief overview of the recent biomass-based synthesis will be advanced. It should be noted that both the chemical and physical properties of the resulting CQDs are deeply dependent on the selected precursors and synthesis methodologies employed, the most affected being quantum yield (QY), oxygen/nitrogen percentage, size, crystallinity, and colloidal stability [6]. The main advantages and disadvantages for each method are illustrated in Table 2.

Table 2. Advantages and disadvantages for the most common CQDs synthesis methods.

\begin{tabular}{|c|c|c|c|}
\hline Method & Advantages & Disadvantages & Ref. \\
\hline $\begin{array}{l}\text { Hydrothermal } \\
\text { synthesis }\end{array}$ & $\begin{array}{l}\text { Good production yields, ease of manipulation, } \\
\text { good production yield of nanomaterials using } \\
\text { high vapor pressure settings }\end{array}$ & Long synthesis duration & [21] \\
\hline Microwave synthesis & $\begin{array}{c}\text { Clean, ease of manipulation, low-temperature, } \\
\text { and economic }\end{array}$ & $\begin{array}{l}\text { Bulk metallic materials unusable } \\
\text { due to electromagnetic field } \\
\text { interferences }\end{array}$ & {$[22,23]$} \\
\hline Electrochemical synthesis & $\begin{array}{l}\text { Ease of operation, potential for mass } \\
\text { production, does not involve harsh or } \\
\text { toxic chemicals }\end{array}$ & Laborious purification processes & [24] \\
\hline Sonochemistry synthesis & $\begin{array}{l}\text { The only general method for doping CQDs } \\
\text { using bulk metals }(\mathrm{Ga}, \mathrm{In}, \mathrm{Bi}, \mathrm{Sn}, \mathrm{Pb}, \mathrm{Cd}, \mathrm{Sb} \text {, } \\
\text { and } \mathrm{Zn})\end{array}$ & Prolonged synthesis process & [25] \\
\hline Laser ablation synthesis & High quality CQDs, swift synthesis & $\begin{array}{l}\text { Low reproducibility; difficulty in } \\
\text { correlating experimental conditions } \\
\text { with obtained CQDs properties }\end{array}$ & {$[26,27]$} \\
\hline Biomass synthesis & $\begin{array}{l}\text { Simple, cost effective, and easily available } \\
\text { in nature }\end{array}$ & $\begin{array}{l}\text { Possible environmental } \\
\text { contamination; necessity of } \\
\text { additional chemical modifications } \\
\text { to increase QY }\end{array}$ & {$[16,28]$} \\
\hline
\end{tabular}

\subsection{Hydrothermal/Solvothermal Synthesis}

The hydrothermal/solvothermal synthesis is one of the most utilized approaches, since it allows the production of large quantities of CQDs with high QY and has a simple experimental arrangement [21]. This approach allows the usage of a broad temperature range that spans from room temperature to very elevated temperatures. Additionally, the hydrothermal/solvothermal synthesis enables the obtention of nanomaterials using experimental settings that employ high vapor pressures with a good production yield. Both the morphology and composition of nanosystems can be controlled by the manipulation of the vapor pressure of the reaction and by liquid phase or multiphase reactions, respectively [29]. Generally, small organic precursors are either dissolved or dispersed (in the 
case of polymers) in water, and then the obtained mixture is transferred to a Teflon-lined stainless-steel autoclave. Afterward, the exposure of the mixture to high temperatures will allow the formation of carbon cores that will constitute the foundation for the growth into CQDs [21].

In 2019, Xue et al. [30] engineered lignin hybridized CQDs (L-CQDs) through a facile one-pot hydrothermal method using alkali lignin in the presence of different molar ratios of citric acid and ethanediamine and concluded that L-CQDs synthesized with equal molar ratio of citric acid and ethanediamine presented the highest fluorescence intensity. The L-CQDs displayed good water dispersibility and a near spherical morphology inferior to $10 \mathrm{~nm}$ in diameter, arranged mainly in interunit linkages and aromatic ring structures. As for the optical properties, the L-CQDs manifested an excitation dependent emission behavior, with emission maximum varying from 454 to $535 \mathrm{~nm}$ under excitation at 375-460 nm. An increase in excitation wavelengths resulted in red-shift in the maximum emission of the L-CQDs to a longer wavelength with a decrease in fluorescence intensity. The L-CQDs had good cellular internalization and displayed low cytotoxicity to HeLa cells. Synthesis of CQDs, utilizing aconitic acid (AA) as the carbon precursor and ethylenediamine as the co-doping reagent through a hydrothermal reaction, was carried out by Qian et al. [31]. The produced CQDs were water soluble and exhibited an excitation independent emission behavior. They presented a bright blue fluorescence and an absolute QY of $56.5 \%$ in aqueous solution. Furthermore, the CQDs intrinsic fluorescence was quenched by folic acid (FA) through their conjugated interaction, which lead to the development of a folic acid fluorescent sensor with a detection limit of $40 \mathrm{~nm}$. Thus, CQDs were used in the detection of folic acid in pharmaceutical and food products with average recoveries in the range of 95.0-105.3\% and relative standard deviation of less than $6.5 \%$. Additionally, considering the qualitative differences in folic acid receptor expression on the surface of different cell types, the conjugated interaction of folic acid and CQDs allowed the distinction of Hela, SMMC-7721, and A549 cells. Therefore, the prepared FA-AA-CQDs could enter the cells by receptor-mediated endocytosis. Zhang et al. [32] reported the synthesis of chiral CQDs from cysteine, and citric acid through the hydrothermal method. The thus synthesized CQDs were constituted by $52.27 \%$ carbon, $14.45 \%$ nitrogen, $27.57 \%$ oxygen, and $5.71 \%$ sulfur. Moreover, the chiral CQDs were stable under several $\mathrm{pH}$ values, temperatures, and ionic strengths, and the location and intensity of the CQDs signal remained unchanged, verified by circular dichroism spectroscopy. Taking into consideration the chiral CQDs properties, they were utilized for the first time for the determination of the systemic effect of these nanomaterials on plants. Therefore, while it was determined that both D-CQDs and L-CQDs could promote the growth and photosynthetic capacity of the mung bean plant, D-CQDs manifested outstanding efficiency. Prathumsuwan et al. [33] produced multi-colored CQDs from succinic acid and glycerol through a one-step hydrothermal synthesis and without requiring acid or base catalysts. By varying the reaction time, blue and green-fluorescent CQDs could be obtained, with QY values of $11 \%$ and 7\%, respectively. The blue-fluorescent carbon dots displayed turn-off fluorescence upon addition of $\mathrm{H}_{2} \mathrm{O}_{2}$ and turn-on fluorescence upon addition of $\mathrm{Fe}^{2+}$, and thus were evaluated as dual-mode sensors for the detection of these two substances. Therefore, CQDs were incorporated in a paper-based sensor system that determined $\mathrm{Fe}^{2+}$ and $\mathrm{H}_{2} \mathrm{O}_{2}$ concentrations as low as $30 \mu \mathrm{m}$ and $400 \mathrm{~nm}$, correspondently, in real water samples. The CQDs were also included in polymeric materials and tested for cell imaging applications. The schematic representation of the synthesis process and application is illustrated in Figure 2. 

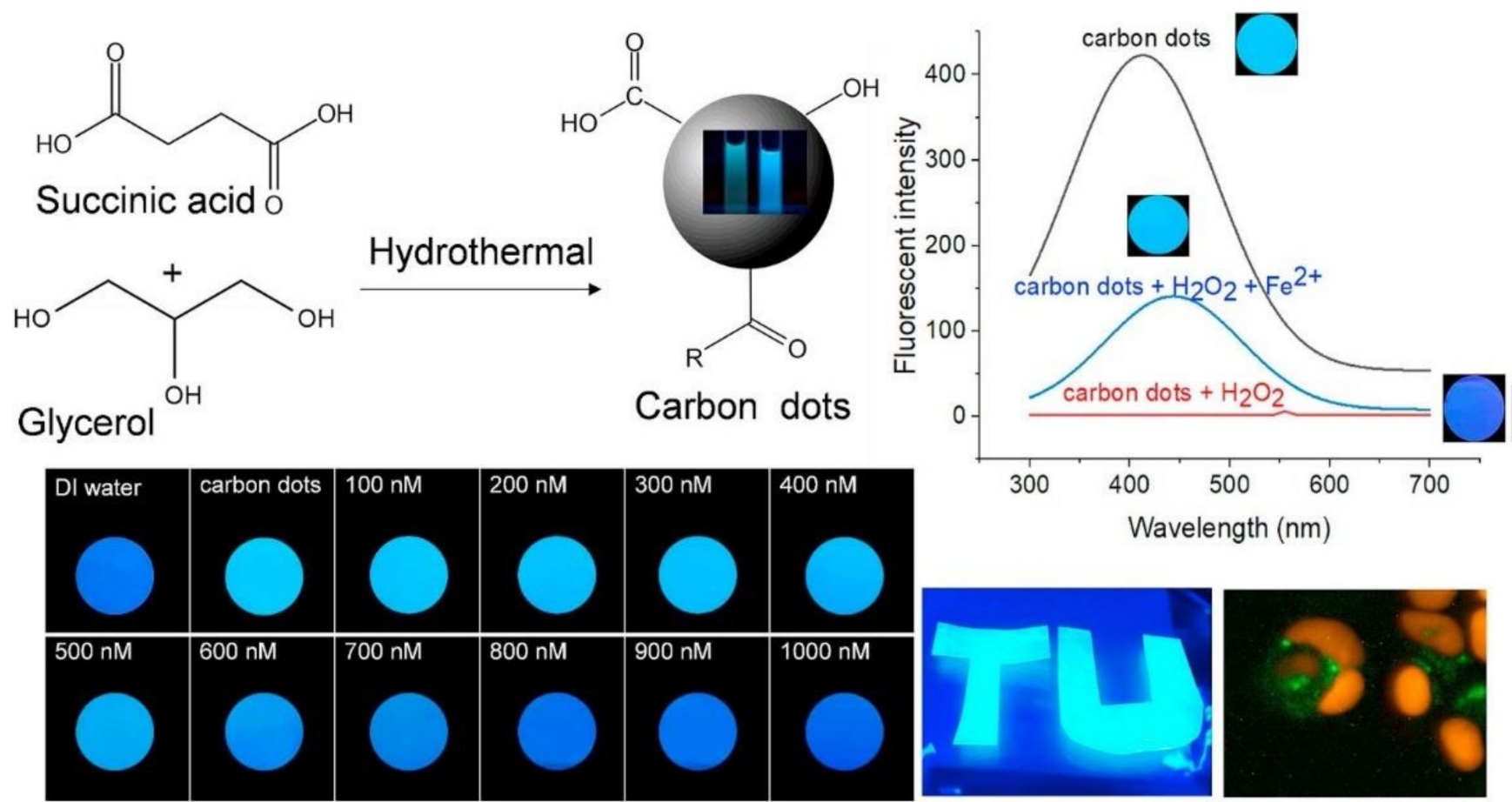

Figure 2. Representation of CQD hydrothermal synthesis, CQDs under UV illumination and practical application. Reprinted from ref. [33], with permission from Elsevier.

In 2020, Khan et al. [34] manufactured nitrogen and sulfur co-doped CQDs (NSCQDs) in a facile one step hydrothermal synthesis using L-Lysine and thiourea. The resultant NS-CQDs were water soluble and exhibited a QY of $53.19 \%$, with a strong blue fluorescence under excitation of a $365 \mathrm{~nm}$ wavelength light source. The NS-CQDs had an excitation dependent behavior and an average diameter size of $6.86 \mathrm{~nm}$. The NS-CQDs were employed as a fluorescent probe relying on the Förster Resonance Energy Transfer (FRET) mechanism for the detection of picric acid in aqueous solution, revealing an adequate linear response to picric acid in the concentration range 1-10 $\mu \mathrm{m}$ with a detection limit of $0.24 \mu \mathrm{m}$. The concentration of picric acid in real water samples was also determined. Baragau et al. [22] reported a continuous hydrothermal flow synthesis of nitrogen doped CQDs (NCQDss) using citric acid and ammonia as precursors. Readily dispersed in water, the as-synthesized NCQDss displayed an excitation independent behavior with highest emission intensity at $441 \mathrm{~nm}$, and also displayed a narrow Full Width at Half Maximum (FWHM). The NCQDss had an average size of $3.3 \pm 0.7 \mathrm{~nm}$. Due to the NCQDss substantial selectivity and sensitivity as a fluorescence sensor for chromium (VI) ions that was caused by the inner filter effect, the NCQDss were applied to the chemical sensing of $\mathrm{Cr}$ (VI) ions in aqueous solutions.

\subsection{Microwave-Assisted Synthesis}

Microwave-assisted technique is recognized as a quick, clean, and low-cost synthesis method that is a sustainable method identified with the Green Chemistry demands. It has been extensively utilized in the production of carbon-based nanomaterials, since the usage of microwave radiation allows an uniform heating and fast heating rates and interacts strongly with carbon materials; another feature that exalts the employment of microwaveassisted methods is the manipulation of internal and volumetric heating of materials [23]. Microwave-assisted techniques rely on causing heating at the molecular-level due to the alternating electric and magnetic fields that interact with the dipole moment of polar molecules present in a solvent. The heat that is generated through this interaction is termed dielectric heating and is absorbed by the carbon precursors. In opposition to conventional heating processes, microwave radiation infiltrates the target materials and 
generates thermal energy at atomic/molecular degrees, which in turn promotes steady and consistent volumetric heating [35]. Due to the ability of producing carbon-based nanomaterials in short-reaction times, low energy consumption, and accurate control of the reaction temperature, microwave assisted techniques have been extensively employed in green synthesis approaches [2]. However, despite the numerous advantages that can be enumerated for the use of microwave radiation in CQDs production, this method still presents some limitations. For example, the use of bulk metallic materials is restricted, since it causes interferences with the electromagnetic field to the point of making this kind of materials unusable either for synthesis or processing relying on microwave irradiation. However, this limitation is easily cleared by the usage of metal particles if the particle size is small enough to avoid the reflection of the incident waves [35].

Uriarte et al. [36] have synthesized CQDs through a one-pot microwave assisted synthesis using glycerol and urea. The synthesis was fast, having only lasted $4 \mathrm{~min}$. The obtained CQDs presented an average diameter of $13.2 \mathrm{~nm}$ with about $9.8 \%$ of QY. CQDs also displayed significative photostability, since their fluorescent intensity did not suffer alterations after $1 \mathrm{~h}$ of continuous light irradiation at $345 \mathrm{~nm}$, although CQDs fluorescence did manifest a pH-dependent behavior, exhibiting an optimal luminescence emission when the $\mathrm{pH}$ was lower than 4.0. The CQDs interaction with tetracyclines compounds was then evaluated, revealing a fluorescence quenching on the native fluorescence of the CQDs, which can be attributed to a static quenching, possibly correlated with the formation of a ground-state complex between tetracyclines and CQDs. Therefore, a fluorescence assay was developed for the quantification of tetracyclines, which showed good linearity range between 0.5 and $25 \mu \mathrm{m}$ and a detection limit of $165 \mathrm{~nm}$. The method was used for the analysis of urine samples with good recoveries (94.7-103\%) and precision (4.6 RSD\%). In 2019, Lu et al. [37] produced N-doped CQDs from gallic acid, citric acid, and ethylenediamine by a microwave assisted-synthesis. The synthesized CQDs fluorescence intensity was stable at different ion concentrations, but the prolonged exposure to ultraviolet light lead to a decrease in fluorescence. The CQDs maintained their fluorescence in the $\mathrm{pH}$ range between 5-9, and the maximum fluorescence intensity was observed when $\mathrm{pH}$ was 5 . The QY of the developed CQDs was determined to be $25 \%$. After testing for antitumor activity by MTT assays and in vivo antitumor experiments, it was revealed that CQDs retained the antitumor activity of their precursor, gallic acid. The CQDs presented an outstanding antitumor activity towards HeLa cells in a dose dependent manner. Hinterberger et al. [38] developed white light emitting CQDs by microwave-assisted synthesis utilizing as precursors o-phenylene-diamine and citric acid. The microwave irradiation originated CQDs with blue fluorescence and, also, the yellow-emitting molecule 2,3-diaminophenazine (DAP). A suggested molecular mechanism for the formation of CQDs and DAP is displayed in Figure 3. Hence, the resulting solution exhibits two fluorescence emission peaks at 430 and $560 \mathrm{~nm}$, which correspond to CQDs and DAP, respectively. The size of the CQDs was determined by AFM to be $1.1 \pm 0.3 \mathrm{~nm}$. The emission of white light was achieved by varying the $\mathrm{pH}$ value of the solution, since the intensity ratio of both fluorescence peaks depends on $\mathrm{pH}$, which is caused by the protonation state of DAP. At a $\mathrm{pH}$ value of 5.4, both blue and yellow emission intensities are similar and thus the light emitted is white. 
(a)<smiles></smiles>

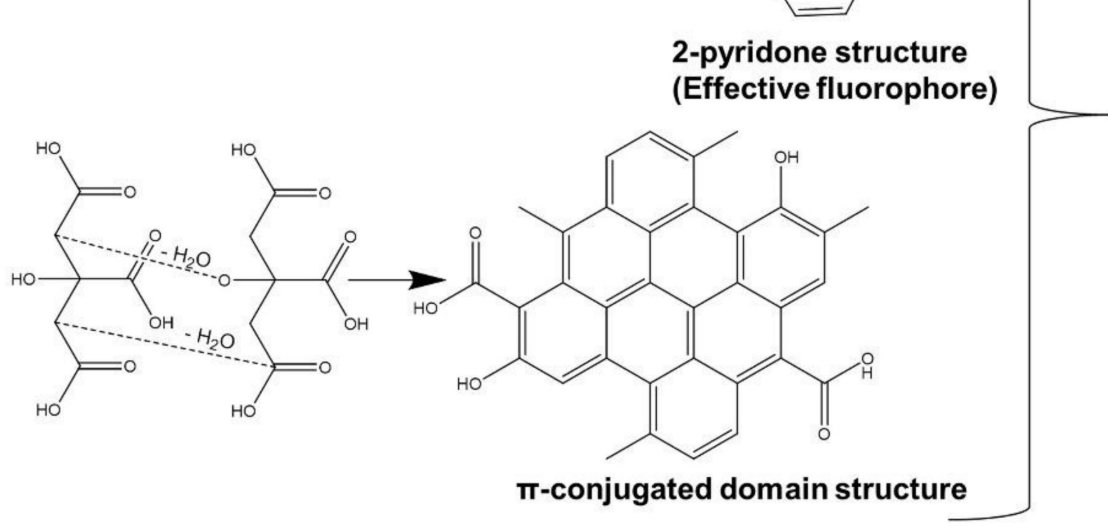

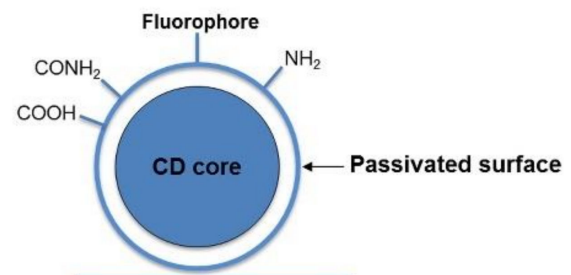

Blue emitting CD

(b)<smiles>N=C1C=CC(C(=O)O)=CC1=N</smiles><smiles>N=C1C=CC=CC1=N</smiles><smiles>Nc1cc2nc3ccccc3nc2cc1N</smiles>

Yellow emitting DAP

Figure 3. (a) Formation of CQDs from citric acid and o-phenylenediamine; (b) formation of DAP by oxidative dimerization of $o$-phenylenediamine. Reprinted from ref. [38], with permission from Elsevier.

Seifikar et al. [39] manufactured CQDs utilizing glucose and polyethylene glycol (PEG) by microwave-assisted synthesis. The reaction mixture was irradiated twice, first at $700 \mathrm{~W}$ for $15 \mathrm{~min}$, and later after the addiction of $5 \mathrm{~mL}$ of $\mathrm{NaCl} 3.0 \mathrm{~mol} \mathrm{~L}^{-1}$, at $540 \mathrm{~W}$ for $2 \mathrm{~min}$. The $\mathrm{NaCl}$ was used, since it triggers the precipitation of the dispersed CQDs. Characterization revealed the obtained product was comprised of both nano and micro-size particles. After the characterization, the CQDs were applied and tested in the adsorption of two cationic dyes, methyl violet (MV) and cationic blue (CB), present in water, revealing that the adsorption rate onto the obtained nanomaterial was swift, taking only a few seconds. The adsorption rate was found to be influenced by temperature. In 2020, $\mathrm{Li}$ et al. [40] synthesized far-red CQDs (FR-CQDs) by treating glutathione dissolved in formamide with ultrasounds and then submitting the mixture to microwave irradiation for $3 \mathrm{~min}$ at $800 \mathrm{~W}$. The obtained FR-CQDs had a QY of $18.50 \%$. After purification (centrifugation at 10,000 $\times g \mathrm{rpm}$ for $5 \mathrm{~min}$, followed by dialysis (molecular weight cutoff of $3500 \mathrm{Da}$ )), the FR-CQDs were mixed with a suspension of chloroplasts in a sucrose buffer solution for $30 \mathrm{~min}$ at $4{ }^{\circ} \mathrm{C}$ to obtain FR-CQDs/chloroplast complexes. FR-CQDs allow for a more efficient photosynthesis, since they mediate the conversion of ultraviolet A (UV-A) light into $625-800 \mathrm{~nm}$ far-red emission, which can be directly absorbed and utilized by chloroplasts. The prepared FR-CDs/chloroplast complexes were then tested in vitro and in vivo for the improvement of photosynthetic activity of the Roman lettuce. The in vitro model displayed higher electron transfer efficiency between PS II (photosystem II) to PS I (photosystem I), and the in vivo experiment revealed an increase of fresh and dry weights, which confirms higher electron transfer rate compared with the control group. In 
addition, red carbon dots (R-CDs) and blue carbon dots (B-CDs) were also synthesized. In 2018, Li et al. [24] have manufactured N- and S-co-doped carbon quantum dots (NSCQDss) via a single step microwave-assisted synthesis, using ammonium citrate and L-cysteine as precursors. Both reagents were firstly dissolved in $10 \mathrm{~mL}$ ultrapure water, followed by a 2-min sonication, allowing the formation of a transparent solution. The synthesis required a $750 \mathrm{~W}$ microwave oven and was completed in $2.5 \mathrm{~min}$. The obtained NSCQDss exhibited a QY value of $64 \%$ and displayed bright blue fluorescence when exposed to an excitation wavelength of $353 \mathrm{~nm}$, with an emission maximum at $426 \mathrm{~nm}$. The NSCQDss presented an average size of $2 \mathrm{~nm}$. Afterward, the synthesized NSCQDss were used for the analysis of levofloxacin in real water samples, with significative selectivity and sensitivity. Recoveries of levofloxacin in the real water samples were $98.6-106.8 \%$, with a linear range of $0.01-70 \mathrm{mg} \mathrm{L}^{-1}$ and a detection limit of $5.1 \mu \mathrm{g} \mathrm{L}-1$.

\subsection{Others}

\subsubsection{Electrochemical Synthesis}

Generally, the electrochemical synthesis entails the use of three electrodes, the working electrode comprised by a carbon precursor, as well as the counter and reference electrodes. Different results may be obtained depending on the employed carbon precursor and the utilized experimental setup [12]. Concerning the most usual carbon precursors, carbon fiber, graphene and graphite are extensively used, making this synthesis approach of low cost and appliable to mass production of CQDs. This methodology also presents the advantage of utilizing common raw materials and not resorting to environmentally aggressive chemicals. Despite these advantages, the fact that the purification processes of the obtained CQDs are laborious and time-consuming is perceived as a significant drawback to this synthesis method [41].

Niu et al. [42] reported the synthesis of green-fluorescent $\mathrm{N}$-doped carbon quantum dots (N-CQDs) prepared by a bottom-up electrochemical (EC) method, using pyrocatechol and ethylenediamine as both precursors and electrolytes. The QY value for N-CQDs was verified to be $30.6 \%$. Then, the produced N-CQDs were employed in a turn ON-OFF$\mathrm{ON}-\mathrm{OFF}$ fluorescence assay for the monitoring of alkaline phosphatase activity, based on the specific competitive interaction of N-CQDs with $\mathrm{Fe}^{3+}$ and pyrophosphate anions, as well as the hydrolysis of pyrophosphate anions in the presence alkaline phosphatase. Huang et al. [43] developed ionic liquid-functionalized carbon dots (IL-CDs) using the ionic liquid 1-butyl-3-methylimidazolium tetrafluoroborate, via electrochemical method. These IL-CDs were then incorporated in a ratiometric fluorescent assay, which also included 2,3-diaminophenazine (DAP), for the evaluation of alkaline phosphatase activity based on FRET. IL-CDs presented a blue fluorescence signal at $470 \mathrm{~nm}$ and 2,3-diaminophenazine (DAP) had a yellow fluorescence signal at $570 \mathrm{~nm}$.

\subsubsection{Sonochemical Synthesis/Ultrasonic Treatment}

The sonochemical method is yet another green synthesis methodology, since it allows the production of large quantities of CQDs without the usage of harmful or toxic substances. The method consists in providing high-power ultrasonic waves to the reaction mixture, which in turn will cause cavitation, the formation of high-pressure vapor bubbles in the solvent [25]. The conversion of ultrasonic waves into mechanical energy allows the formation of CQDs through nucleating events, polymerization, and/or aromatization [15]. The regulation of the frequency and power of the ultrasonic waves, sonication time, and carbon precursors utilized is important to define the physical and chemical properties of the generated CQDs. Advantages to this technique are the single step synthesis of considerable amounts of CQDs and the fact that the sonochemical method is the only method for doping CQDs with bulk metals (including Ga, $\mathrm{In}, \mathrm{Bi}, \mathrm{Sn}, \mathrm{Pb}, \mathrm{Cd}, \mathrm{Sb}$, and $\mathrm{Zn}$ ) [44]. 
In 2019, He et al. [45] have manufactured for the first time CQDs-based lubricants from citric acid, urea, and poly(ethylene glycol) (PEG), by sonochemical synthesis. The reaction mixture was submitted to ultrasonic treatment for $60 \mathrm{~min}$ at room temperature, producing CQDs with an average size of $2.38 \mathrm{~nm}$ and highly efficient lubricating properties. Lu et al. [46] reported the synthesis of CQDs via sonochemistry utilizing dopamine dissolved in dimethylformamide. The as-produced CQDs had a QY of $3.6 \%$ and a maximum emission at $434 \mathrm{~nm}$ upon $350 \mathrm{~nm}$ excitation. Size distribution ranged from $2.5-5.5 \mathrm{~nm}$. The CQDs were used in the detection of $\mathrm{Fe}^{2+}$ ions both in water and in the interior of cancer cells, and also interestingly were shown to be temperature-dependent, allowing them to act as temperature sensors, both in water and in cells. Leong et al. [26] produced CQDs from curcumin dissolved in ethanol, resorting to the combination of mechanical and ultrasonic milling techniques. The average size of CQDs was $13.7 \mathrm{~nm}$. The CQDs were then evaluated in vitro on their antibacterial activity, revealing a broad-spectrum bacteriostatic activity.

\subsubsection{Laser Ablation}

Laser ablation has been used to synthesize nanoparticles since the nineties. It consists of solid targets immersed in either liquid (laser ablation of solids in liquids-LASL) or vapor. LASL presents the advantage of allowing the production of CQDs of substantial quality in a rapid process, with or without employing surface functionalization. By modifying experimental physical conditions, such as pulse duration, wavelength, repetition rate, and fluence of the incident laser or, on the other hand, the nature of the liquid media and target materials utilized, LASL allows the manufacturing of CQDs with distinct optical and chemical properties. Nevertheless, the deficiency in data correlating physical parameters that modulate aspects such as size or optical properties of the synthetized CQDs restricts laser ablation use in their synthesis. Additionally, despite identical experimental settings, reproducibility is often lower than expected, presenting a major challenge for laser ablationbased synthesis of CQDs [27,47].

Isnaeni et al. [48] fabricated toluene-soluble CQDs from coconut fiber resorting to laser ablation. Depending on the excitation wavelengths, the CQDs presented distinctive emission peaks at the wavelengths of 300,440 , and $540 \mathrm{~nm}$, corresponding to the $\pi$ orbital state, $\sigma$ orbital state, and surface state, respectively. The transfer of energy between the surface state and the $\sigma$ orbital state was considered very likely, while no correlation was found between $\pi$ orbital state and the surface state. The electron decay time in the CQDs surface state was found to be very brief. Nguyen et al. [28] synthesized ultrasmall CQDs via double-pulse femtosecond laser ablation in solution, using graphite powders dispersed into ethanol. The minimum size of CQDs was $\sim 1 \mathrm{~nm}$ when the laser pulses approached electron-ion relaxation time, obtaining smaller CQDs than those produced via single-pulse ablation with the same laser fluence.

\subsubsection{Natural Sources/Biomass/Waste Products}

The use of natural sources and waste products in CQDs synthesis qualifies underused and undervalued inexpensive resources to be converted in nanomaterials in a simple and cost-effective way. Several methods may be exploited to manufacture CQDs with properties tailored to the application in mind, such as microwave-assisted, electrochemical, confined pyrolysis, or solution chemistry methods. Those methodologies have the advantage of preventing CQDs agglomeration, as well as allowing the production of highly biocompatible CQDs. However, the usage of these kinds of starting materials presents the disadvantage of the necessity of surface passivation and doping methods to obtain higher QY. Additionally, it should be pointed out that the possibility of contamination from environmental pollution cannot be disregarded, particularly when the synthesized CQDs are to be used in biomedical applications. This problem can be overcome, once again, by surface passivation, providing, for example, a polymer layer over the CQDs [16,49]. 
Ren et al. [50] developed N-doped micropore CQDs passivated with formamide utilizing the pulsed laser ablation (PLA) method and using waste Platanus biomass as the carbon precursor. The $\mathrm{N}$-doped micropore CQDs displayed dual-wavelength coexisting fluorescence emissions in the indigo-blue wavelength region, suggesting the transition of the excited electrons from the intrinsic $\pi^{*}$ orbital to the surface state produced from the saturation passivation. Characterization studies determined QY to be as high as $32.4 \%$ and fluorescence lifetime to be $6.56 \mathrm{~ns}$, highlighting the importance of the nitrogencontaining functional group in the augmentation of the QY, when compared to CQDs without nitrogen in their composition. The produced N-doped micropore CQDs had an excitation independent emission behavior in various conditions such as varying $\mathrm{pH}$ values, temperatures, excitation wavelengths, salt ionic concentrations, and irradiation times. Posteriorly, the N-doped micropore CQDs were employed in cell bioimaging of HeLa cells, L02 cells, and macrophage cells and have been shown to be well internalized. In 2018, Devi et al. [51] reported the synthesis of CQDs from aloe-vera extract by a facile one-step pyrolysis method, with optimal synthesis conditions fixed at $190{ }^{\circ} \mathrm{C}$ and $20 \mathrm{~min}$ of synthesis time. The obtained product was subjected to dilution with water followed by the purification against water in a $0.3 \mathrm{kDa}$ dialysis membrane. Characterization revealed the existence of carboxyl and hydroxyl functional groups on the CQDs surface, a bright blue luminescence under UV light and a QY of $12.3 \%$. Additionally, the CQDs presented an excitation independent emission behavior. Following, the CQDs were applied for Fe (III) sensing in water and tested for their light-activated antibacterial activity against Escherichia coli and Staphylococcus aureus. Bhamore et al. [52] produced multi-color CQDs (blue, green, and yellow) using Manilkara zapota fruits, $\mathrm{H}_{2} \mathrm{SO}_{4}$, or $\mathrm{H}_{3} \mathrm{PO}_{4}$ at either 80 or $100{ }^{\circ} \mathrm{C}$, and selected time settings that varied between 15 to $60 \mathrm{~min}$. The synthesized CQDs had average sizes of $1.9 \pm 0.3,2.9 \pm 0.7$, and $4.5 \pm 1.25 \mathrm{~nm}$ for blue, green, and yellow CQDs, respectively. The obtained CQDs demonstrated good dispersibility, presented good QY values (5.7\%, 7.9\%, and 5.2\% for blue-, green-, and yellow- C-dots), and manifested excitation-dependent emission behavior. The CQDs were then used as imaging agents for observation of Escherichia coli, Aspergillus aculeatus, and Fomitopsis sp. organisms.

\section{Structure Modifications}

\subsection{Heteroatom Doping}

The inclusion of both non-metallic and metallic elements in the CQDs is responsible for a shift in the electronic distribution, affecting the energy gap between HOMO (Highest Occupied Molecular Orbital) and LUMO (Lowest Unoccupied Molecular Orbital), and causing modifications on the surface configuration. Thus, the modulation triggered by the dopants is directly accountable for the properties exhibited by the synthesized CQDs and so, by manipulating both the nature and quantities of the elements employed, it is possible to boost and tune the fluorescence properties of CQDs. In terms of the type of dopant utilized, it is known that while non-metallic elements can reorganize the band arrangement of CQDs, metallic dopants are used to avoid unwarranted depletion of carboxyl and amino functional groups in the starting materials, particularly during the carbonization and dehydration steps of the synthesis, due to the chelation between the mentioned chemical groups and metal ions [53]. Considering that most metals present varying degrees of toxicity and are, therefore, inadequate for most biomedical and pharmaceutical applications, this section will provide a more in-depth vision of non-metallic heteroatom doping of CQDs. Recent progress in heteroatom doping has been illustrated in Figure 4. 


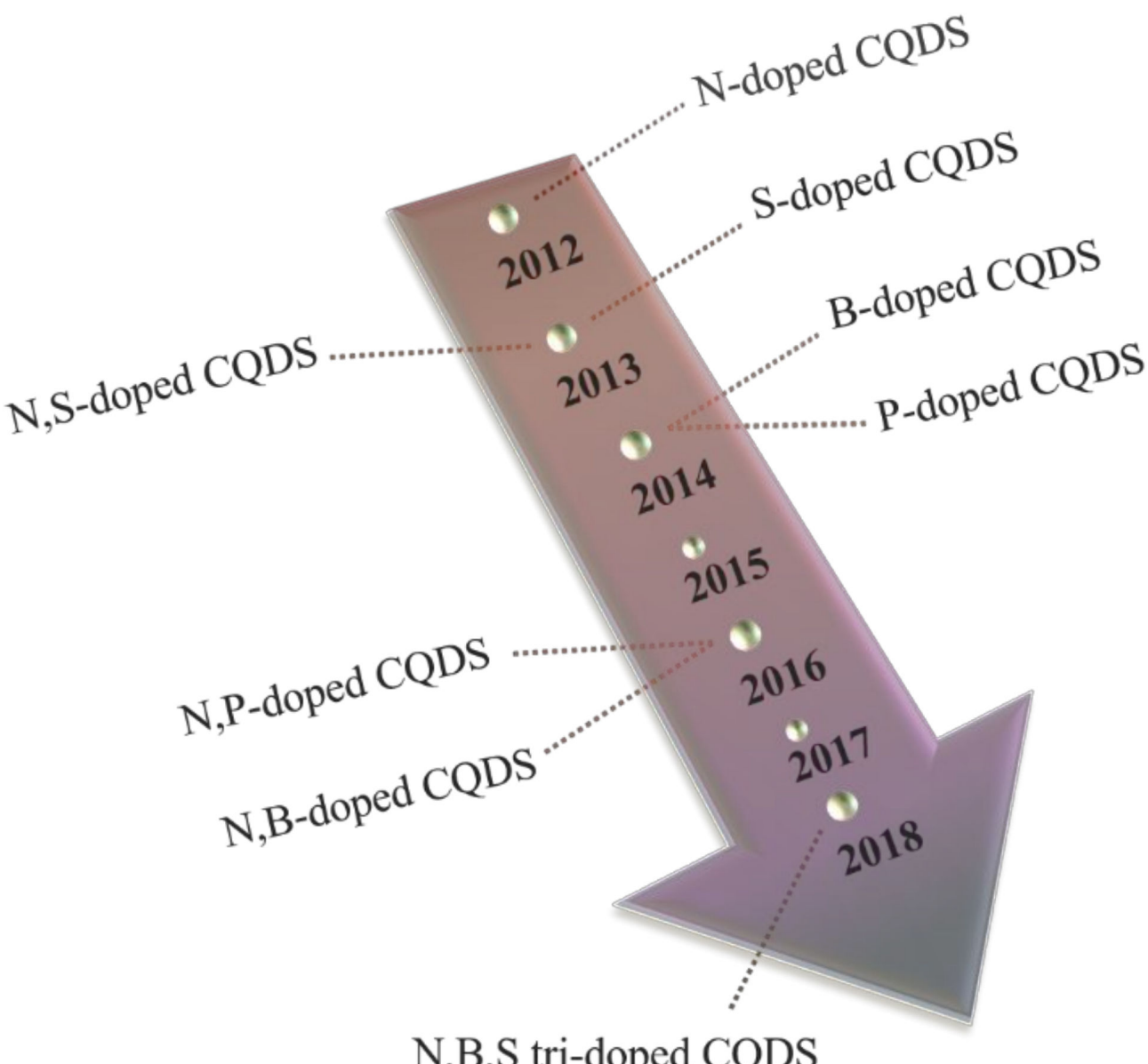

Figure 4. Heteroatom doping progress timeline.

\subsubsection{Single Heteroatom Doping $\mathrm{N}$-Doped CQDs}

Considering the frequently modest QYs exhibited by "naked" CQDs and the fact that nitrogen atoms possess five valence electrons and similar atomic size to carbon atoms, $\mathrm{N}$-doping is an approach usually utilized, since it bestows and/or enhances several of CQDs already exceptional properties [54,55].

Zhao et al. [56] have produced nitrogen-doped carbon quantum dots (N-CQDs) utilizing polyacrylamide, as it is a carbon- and nitrogen-rich precursor, by hydrothermal synthesis. Besides excellent water solubility, the N-CQDs possessed a QY of $23.1 \%$ and several surface functional groups, such as carboxyl acids and amines. Thus, the N-CQDs were evaluated as fluorescent nano-probes for sensitive and selective detection of dopamine. Through the conversion of dopamine into dopamine-quinone under alkaline conditions, a relationship between fluorescence quenching and the concentration of dopamine was established. A good linear correspondence was defined between these two parameters, and the concentration of dopamine in the range $0.1-200 \mu \mathrm{m}$ was attained with a low detection limit of $0.05 \mu \mathrm{m}$. The developed method was then applied to the quantification of dopamine in urine samples. In 2020, Meng et al. [57] fabricated N-doped CQDs (N-CQDs) by one-pot hydrothermal synthesis from $p$-phenylenediamine and ammonia. The synthesized N-CQDs were uniform and monodispersed, with an average size of $3.2 \mathrm{~nm}$ and a QY of $13.2 \%$. The CQDs manifested excitation dependent emission behavior. Then, the CQDs were used in a multi-sensing platform for the detection of chromium (VI), 2,4,6-trinitrophenol, and ascorbic acid, based on the inner filter effect (IFE). Bandi et al. [58] developed hydrothermally synthesized N-CQDs from o-phenylenediamine (OPD) and 2,5 pyridinedicarboxylicacid (2,5 PDC). The N-CQDs displayed a high QY value of $47 \%$ and excitation tunable emission 
behavior dependent on the $\mathrm{pH}$ value of the solution, which is caused by the participation of surface states, supporting their influence in the origin of excitation dependent nature. Furthermore, the as-prepared N-CQDs were employed in the individual determination of both $\mathrm{Cu}$ (II) and Fe (III) ions in spiked water, serum, and urine samples, by UV-visible spectra and fluorescence lifetime analysis.

\section{B-Doped CQDs}

Heteroatom doping of CQDs with boron atoms is accountable for a marked improvement in the fluorescence properties of CQDs [59]. Zhang et al. [60] have reported the synthesis of B-doped CQDs by the hydrothermal method using citric acid and boric acid as carbon and boron sources, respectively. The B-CQDs had an average size of $2.3 \mathrm{~nm}$ composed of multi lattice planes. Characterization studies revealed $-\mathrm{COOH},-\mathrm{OH}, \mathrm{C}=\mathrm{O}$, and C-B functional groups and QY values of $30.85 \%$ and $17.92 \%$ for B-CQDs and plain CQDs, correspondingly. Afterward, the B-CQDs were tested as fluorescence probes for chemical control of amoxicillin in aqueous solution. Linear response between the enhancement of B-CQDs native fluorescence and amoxicillin concentration was observed when amoxicillin was present in solution in the range of 1.43-429.12 $\mu \mathrm{mol} \mathrm{L}^{-1}$. Yong et al. [61] prepared boron-doped CQDs (B-CQDs) through a one-step hydrothermal method from phenylboronic acid. The as-synthesized B-CQDs presented an average size of $3.3 \mathrm{~nm}$ and a fluorescent excitation/emission profile at the wavelengths of $247 / 323 \mathrm{~nm}$. The QY was determined to be $12 \%$. Posteriorly, the B-CQDs were utilized as fluorescent probes for both sorbate and vitamin B12 determination in bread, vinegar or mineral water, and vitamin B12 tablets, vitamin drink, or mineral water, respectively. Other real samples were a source for interferences due to coexisting of food colorants.

\subsubsection{Co-Doping Multiplex Heteroatoms $\mathrm{N}, \mathrm{P}-\mathrm{co}-\mathrm{CQDs}$}

While single heteroatom doping with nitrogen grants access to active sites that can enhance optical properties of CQDs by creating surface defects due to carbon atoms replacement, some N-CQDs present low aqueous dispersity. On the other hand, the co-doping CQDs with nitrogen and phosphorous avoids alkaline, acidic, and metal ion interference, while favoring, at the same time, aqueous dispersity [62].

Liping et al. [63] prepared nitrogen and phosphorus co-doped CQDs (N,P-CQDs) from o-phosphorylethanolamine and citric acid via hydrothermal method. The N,P-CQDs displayed a QY of $8.17 \%$ and excitation dependent emission behavior, having an average size of $1.6 \mathrm{~nm}$. Considering the N,P-CQDs fluorescence enhancement when in presence of Cadmium (II) ions, a fluorometric assay was developed for the quantification of $\mathrm{Cd}$ (II) ions, based on the chelation enhanced fluorescence that is induced by the formation of Cd(II)-N,P-CDs complex. Good linear response between Cd (II) concentration and the increase in $\mathrm{N}, \mathrm{P}-\mathrm{CQD}$ s fluorescence was observed when $\mathrm{Cd}$ (II) concentration ranged from 0.5 to $12.5 \mu \mathrm{m}$, and the method had a $0.16 \mu \mathrm{m}$ detection limit. The detection of Cd (II) was performed in spiked serum and urine samples. Omer [64] reported the synthesis of nitrogen and phosphorus co-doped CQDs from glucose and polyethylenimine via a low-temperature carbonization route. The CQDs presented a $25 \%$ QY and a size distribution ranging from 2 to $9 \mathrm{~nm}$. Additionally, the CQDs displayed excitation-independent fluorescence. Then, the CQDs were used as a fluorescent probe for the selective and sensitive detection of copper ions, based on the quenching of CQDs native fluorescence. The determined limit of detection was $1.5 \mathrm{~nm}$. Liu et al. [65] developed nitrogen and phosphorus dual-doped CQDs (NP-CQDs) via a self-exothermic reaction using glucose, 1,2-ethylenediamine, and concentrated phosphoric acid as precursors. QY was determined to be $9.59 \%$, and the $\mathrm{NP}-\mathrm{CQDs}$ had an average size of $3.5 \pm 0.2 \mathrm{~nm}$. The as-produced N,P-CQDs presented excitation-dependent fluorescence behavior. Additionally, the N,P-CQDs were evaluated as fluorescent sensors for determination of curcumin in aqueous solution, obtaining a linear range of $0.5-20 \mu \mathrm{mol} \mathrm{L}^{-1}$ and a detection limit of $58 \mathrm{nmol} \mathrm{L}^{-1}\left(21.37 \mathrm{ng} \mathrm{mL}^{-1}\right)$. The method 
was applied to drinking water and food samples. Additionally, the N,P-CQDs were utilized as fluorescent agents for cellular imaging and did not manifest noticeable cytotoxicity.

\section{N,S-co-CQDs}

Even though single heteroatom doping can be responsible for a modulation in the emission wavelengths of CQDs, such variation is not significant enough to reallocate their emission to longer wavelengths (superior to $600 \mathrm{~nm}$ ). To attune the emission properties of CQDs, the insertion of $\mathrm{N}$ and $\mathrm{S}$ atoms can be employed, as such modification provides additional energy levels between $\pi$ and $\pi^{*}$ of carbon atoms [66].

Liu et al. [67] manufactured N,S-doped CQDs using methionine and citric acid through hydrothermal synthesis. The as-synthesized CQDs manifested excellent water solubility due to the hydroxyl, carboxyl, and amino groups on the CQDs surface, and a QY of $13.8 \%$. The CQDs had an average diameter of $5 \mathrm{~nm}$ and displayed an excitation dependent emission behavior. The average fluorescence lifetime of the CQDs was $3.67 \mathrm{~ns}$. Additionally, the CQDs exhibited outstanding stability under different $\mathrm{pH}$ values and high ionic strength CQDs were then employed in the bioimaging of Hep-2 cells. In 2018, Li et al. [68] produced $\mathrm{N}$,S-doped chiral L (or D)-CQDs by hydrothermal treatment of L (or D)-cysteine. The CQDs had a QY value of $41.26 \%$ and displayed $\mathrm{pH}$-dependent fluorescence intensity due to surface state involvement. The L-CQDs exhibited chirality-dependent enhancement in cellular glycolysis, despite being incapable of influencing the cellular ATP levels of T24 cells. Ding et al. [69] prepared N,S-CQDs via a one-step microwave method utilizing 1,6hexanediamine dihydrochloride and dimethyl sulfoxide as precursors. The as-synthesized N,S-CQDs manifested a QY of $24 \%$ and excitation dependent emission behavior, emitting blue, green, yellow, and orange fluorescence as the excitation wavelength shifts to higher values. The average diameter of the N,S-CQDs was $4.35 \mathrm{~nm}$. The N,S-CDs displayed very good thermal stability and under medium and acidic conditions suffered a fluorescence enhancement. Additionally, the $\mathrm{N}, \mathrm{S}-\mathrm{CDs}$ were employed in the detection of $\mathrm{MnO}_{4}{ }^{-}$and $\mathrm{Cr}_{2} \mathrm{O}_{7}{ }^{2-}$ with detection limits of 0.34 and $0.23 \mu \mathrm{m}$, correspondingly.

\section{$\mathrm{N}, \mathrm{B}-\mathrm{co}-\mathrm{CQDs}$}

Co-doping CQDs with nitrogen and boron atoms enhances their fluorescence QY and seems to be responsible for the obtaining of CQDs with an excitation independent behavior [70].

In 2019, Jiang et al. [71] synthesized B,N-CQDs via hydrothermal synthesis using p-amino salicylic acid, boric acid, and ethylene glycol dimethacrylate as starting materials. The obtained B,N-CQDs had a QY of $19.6 \%$ and an average size of $5 \mathrm{~nm}$. B,N-CQDs maximum excitation and emission wavelengths were 380 and $520 \mathrm{~nm}$, respectively, and were shown to be highly stable under different $\mathrm{pH}$ values, ionic strengths, storage times, and prolonged exposure times to a $365 \mathrm{~nm}$ UV lamp. Afterward, the B,N-CQDs were used as fluorescent probes for the detection of the drug captopril, an angiotensin-converting enzyme (ACE) inhibitor used for the treatment of hypertension, based on an inner filter effect and a static quenching effect. The assay has been utilized for the detection of captopril in mouse plasma. Huang et al. [72] have manufactured N,B-CQDs via a modified hydrothermal method, utilizing 3-aminobenzeneboronic acid (APBA) and 1,2-ethylenediamine (EDA) as precursors. The resulting N,B-CQDs exhibited excitation/emission peaks at 400/510 nm and a fluorescence QY of $47 \%$. Based on an inner filter effect on N,B-CQDs fluorescence, a fluorescence methodology for the detection of $\alpha$-glucosidase activity and its inhibitors in water and living cells was established. Alizadeh et al. [73] have reported the production of nitrogen and boron-doped CQDs from phenylbronic acid, rhodamine $\mathrm{B}$, and $o$-phenylenediamine (OPD) by hydrothermal synthesis. The CQDs presented a QY of $46 \%$ and an average size of $30 \mathrm{~nm}$. The CQDs also exhibited excitation dependent fluorescence behavior. Under different $\mathrm{pH}$ values, the CQDs maintained constant fluorescence intensity. Furthermore, the CQDs were used as fluorescent probes for glucose determination in an RGB technique employing the RGB image capabilities of a smartphone. 


\section{Tri-Doped CQDs}

To accomplish fine-tuning of CQDs optical properties, co-doping with three distinct elements can be applied as a versatile strategy to attain a more controllable adjustment of features such as excitation and emission wavelengths or QY values.

In 2020, Gao et al. [74] developed N/S/P co-doped CQDs through an ultrasonicassisted synthesis, using thiamine pyrophosphate, a natural biological extract, as the sole donor of carbon, nitrogen, sulfur, and phosphorus atoms, in an alkaline solution and room temperature. The reaction was processed in $240 \mathrm{~min}$. The synthesized N/S/P-CQDs were water-soluble, presented bright photoluminescence that was tunable by temperature, and displayed several functional groups, such as $-\mathrm{OH},-\mathrm{COO}-,-\mathrm{C}-\mathrm{S}$, and $-\mathrm{PO}_{3}$. After the synthesis and purification/isolation by dialysis and freeze-drying, a $1 \mathrm{mg} / \mathrm{mL}$ aqueous dispersion of the N/S/P-CQDs was prepared. Moreover, the N/S/P-CQDs were tested as fluorescence probes for tetracycline detection based on the inner filter effect. The methodology showed high sensitivity for the detection of tetracycline in real samples, such as milk and tap water. Huang et al. [75] hydrothermally synthesized sulfur tri-doped CQDs (NPS-CQDs) resorting to $p$-aminobenzenesulfonic acid and tetrakis(hydroxymethyl)phosphonium chloride as precursors. Characterization studies determined the NPS-CQDs to be biocompatible when tested with HeLa MCF-7 cells during $48 \mathrm{~h}$ of incubation. The produced NPS-CQDs manifested excitation/emission maxima at 360 and $505 \mathrm{~nm}$ and exhibited good optical stability. Considering that chromium (VI) presents an absorption maximum at $350 \mathrm{~nm}$, the inner filter effect on the blue fluorescence of the NPS-CQDs was used to produce a rapid, sensitive, and selective fluorometric assay for the determination of chromium (VI) in real waters samples and living cells. The detection limit was determined to be $0.23 \mu \mathrm{m}$, and linear response ranges from 1 to $500 \mu \mathrm{m}$ chromate concentration range. Huang et al. [76] reported the synthesis of red emission nitrogen, boron, and sulfur co-doped CQDs (NBSCQDs). The hydrothermal synthesis was processed by using 3-aminobenzeneboronic acid and 2,5-diaminobenzenesulfonic acid as precursor reagents. The NBS-CQDs exhibited a QY value of $11.6 \%$ and stable optical properties, even under varying $\mathrm{pH}$ values, ionic strengths, and long-time irradiation by UV light. It was also assessed that the synthesized NBS-CQDs presented an excitation independent emission behavior. Owing to the intense quenching on the fluorescence of NBS-CQDs caused by the presence of silver ions, NBSCQDs were employed in the quantification of $\mathrm{Ag}^{+}$ions in a high sensitivity and selectivity fluorescence assay. The quenched fluorescence of NBS-CDs was recuperated after the interaction between $\mathrm{Ag}^{+}$ions and $\mathrm{L}$-Cysteine, thus creating an "ON-OFF-ON" fluorescent probe, which was used in the specific determination of $L$-Cysteine in human urine samples and human plasma samples. This way, low detection limits of $0.35 \mathrm{mmol} \mathrm{L}^{-1}$ for $\mathrm{Ag}^{+}$ions and $0.045 \mathrm{mmol} \mathrm{L}^{-1}$ for L-Cysteine were obtained. Additionally, this principle was applied to visual detections of $\mathrm{Ag}^{+}$ions and L-Cysteine in HeLa and MCF-7 cells.

\subsection{Surface Functionalization}

Considering that surface functional groups are responsible for numerous properties of CQDs, and that the interaction between those groups and other entities, either biological or not, is determinant for CQDs application, surface functionalization is mandatory to obtain high-quality CQDs. When functionalizing the surface, CQDs objective application must be considered, since features such as surface charge status will directly affect both the electrostatic interactions with the target and CQDs fluorescence properties. However, despite the advantages of surface functionalization, the process is often challenging. Several approaches have been entailed to engineer CQDs surface, but the most common consist of binding small organic or biological molecules to the CQDs surface either through covalent bonds, or non-covalent interactions, such as electrostatic interactions or hydrogen bonds. Regarding covalent bonds strategy, carbodiimide chemistry (EDC/NHS) is often employed, as it allows the conjugation of organic, inorganic, biological, or polymeric compounds, presenting either amine or carboxyl functional groups, onto the surface of CQDs, whose surface is coated with carboxyl functional groups. The usual protocol for this reaction 
consists of activation of carboxyl groups by ethyl(dimethylaminopropyl)carbodiimide (EDC)/N-hydroxysuccinimide (NHS), followed by reaction with amino groups [77]. Yet, despite the practicality of this reaction, the hydrolysis of both amine and imino-reactive o-acylisourea structure leads to the formation of products that are frequently unstable in water [78]. Another strategy applied in CQDs surface functionalization other than binding ligands to CQDs surface is passivation with polymers. Considering the importance of surface defects, and functional groups in fluorescence emission processes, it is expected that polymer passivation would lead to an enhancement of CQDs fluorescence properties and the obtainment of superior QY values. By protecting surface functional groups, polymer passivation also shields those groups from processes such as agglomeration or oxidation that could cause a decrease in QY, contributing to an augmentation of CQDs stability. Moreover, the passivation with polymers is responsible for the narrowing of emission bandwidths, significant increases in emission lifetimes, as well as the perfecting of other optoelectronic properties [79]. The grafting of CQDs onto synthetic and biocompatible polymers also prevents agglomeration, and since generally synthetic polymers do not hinder CQDs fluorescence, due to their transparency in the visible region of the electromagnetic spectrum, merging synthetic biocompatible polymers with CQDs creates a fluorescent nanomaterial with excellent biocompatibility and exquisite optical features [80].

\subsubsection{Functionalization with Small Organic Molecules}

In 2019, Abu Rabe et al. [81] synthesized three groups of CQDs by a reflux method. The first group comprised CQDs formed from either 2,2-(ethylenedioxy)bis(ethylamine) (EDA) or 3-ethoxypropylamine (EPA), to establish the effect of different terminal groups/charges on their photo-activated antibacterial activities. The second CQDs group was produced using polyethylenimine (PEI) or the mixture of citric acid and PEI, to determine the effects of CQDs surface charges vs. fluorescent QY on their antimicrobial activities. The third group included CQDs obtained from functionalization with PEI 1200 or PEI 600 and was used for the testing of the effect of molecular weight increase due to surface passivation on their antimicrobial activities. It was concluded that in the first group, CQDs obtained from 2,2-(ethylenedioxy)bis(ethylamine) were more efficient, which could be credited to the positive charges of the amino groups, favoring the interaction between CQDs and bacteria. Analysis of the second group revealed that the same surface charge effect was responsible for a better antibacterial performance, in detriment to QY values. Finally, in the third group, it was established that CQDs functionalized with PEI 600 displayed a more vigorous antibacterial activity. Ostadhossein et al. [82] obtained CQDs from sugars via microwave-assisted synthesis. Then, chiral capping was achieved by carbodiimide-mediated activation of the carboxylates on the CQDs surface, utilizing Nhydroxysuccinimide (NHS) and 1-ethyl-3-(3(dimethylamino)propyl) carbodiimide (EDC). Subsequently, covalent modification using cyclic $\alpha$-amino acids was performed, resorting to proline (Pro), phenylalanine (Phe), histidine (His), tryptophan (Trp), alanine (Ala), and proline methyl ester (ProOMe). A schematic representation of the conjugation of amino acids on the CQDs surface is illustrated in Figure 5. This operation resulted in chirality inversion, which was confirmed by circular dichroism studies. This inversion could be generated by the production of a strained intermediate during surface conjugation of amino acid via carbodiimide coupling. 


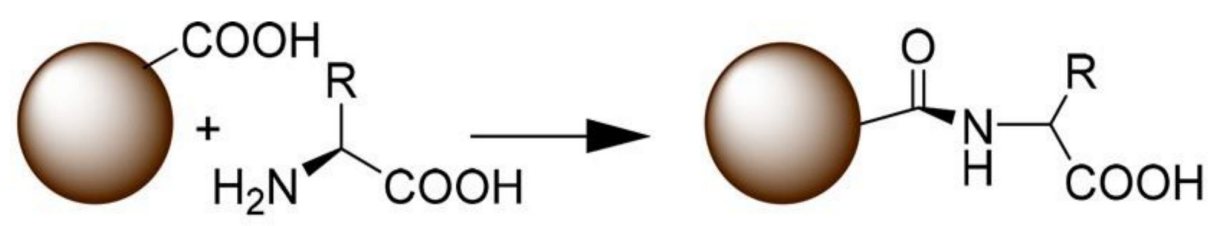

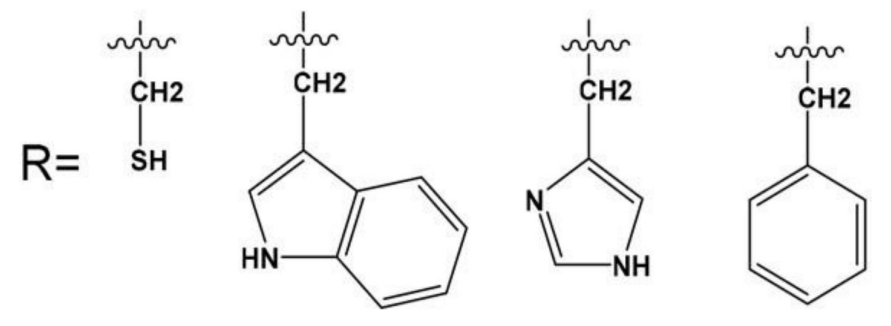
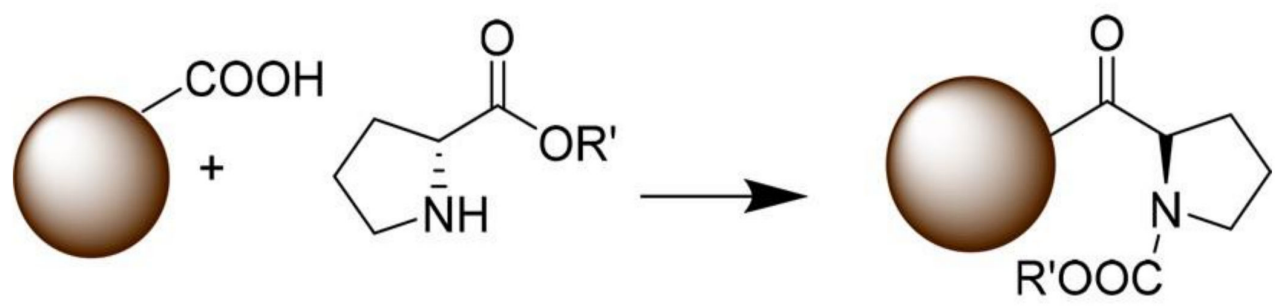

\section{$\mathrm{R}^{\prime}=\mathrm{H}$ or $\mathrm{OMe}$}

Figure 5. Schematic representation of the conjugation of amino acids on the CQDs surface. Reprinted with permission from ref. [82]. Copyright 2018 American Chemical Society.

Kim et al. [83] have prepared soluble CQDs by one-pot hydrothermal synthesis, using L-lysine and L-glutathione. The CQDs showed excitation dependent emission behavior and stability at high temperatures $\left(90^{\circ} \mathrm{C}\right)$, as well as over prolonged periods (over 90 days). The CQDs fluorescence quenching caused by the formation of a complex between thiophenolate anions present on the CQDs surface and metal ions was employed in the selective detection of lead ions in human serum. The quenching effect was generated after the addition of lead ions due to Pearson's hard and soft acid-base principle (HSAB), leading to the transfer of an electron from the conductance band (CB) of CQDs to lead ions. In 2019, Rossini et al. [84] manufactured CQDs resorting to citric acid and tyramine by a one-step microwave-assisted method. The resulting CQDs had an excitation independent emission behavior, suggesting the photoluminescence was originated from the quantum confinement effect. The incorporation yield for tyramine was calculated to be $74 \%$, leaving the unreacted tyramine free to interact with CQDs, causing fluorescence quenching, or it could react with other free tyramine, leading to a non-radiative reaction. The tyramine functionalized CQDs were implemented in paper-based support, and used to monitor glucose in biological samples, by exploiting the $\mathrm{H}_{2} \mathrm{O}_{2}$ formed upon enzymatic reaction with glucose oxidase.

\subsubsection{Functionalization with Biological Molecules}

In 2020, Fahmi et al. [85] synthesized hydrophobic CQDs by a pyrolysis process utilizing tartaric acid and L-tyrosine as starting materials. Afterward, human serum albumin (HSA) was mixed with CQDs and ultrasonicated to drive the CQDs into the hydrophobic core of the HSA. By providing harmonic pressing and expanding force to HSA, the ultrasonic waves facilitated the access of CQDs to the hydrophobic core of HSA when the macromolecule gets the expanding force. The CQDs were employed as staining agents for the HeLa cancer cell via both active and passive targeting. Sahu et al. [86] have fabricated CQDs with citric acid, urea, and boric acid via microwave-assisted 
synthesis. Furthermore, the as-prepared CQDs were submitted to surface modification with bovine serum albumin (BSA), promoted by continuous stirring for $24 \mathrm{~h}$. Since BSA is a native fluorescent molecule, fluorescence bands at $444 \mathrm{~nm}$ and around $300 \mathrm{~nm}$ were observed, caused by CQDs and BSA modified CQDs, respectively. BSA fluorescence is mainly attributed to two tryptophan (Trp) residues situated on the protein surface. The BSA modified CQDs were utilized for the sensitive and selective detection of $\mathrm{Pb}$ (II) ions in pure solutions, in the range 1-10 ppb concentration (limit of detection of $0.08 \mathrm{ppb}$ ). Yang et al. [87] obtained CQDs using citric acid, folic acid, and branched polyethyleneimine (BPEI), which were dissolved in water by ultrasonic oscillation treatment. The mixture was then submitted to hydrothermal heating. For the covalent binding of $\beta$-cyclodextrin, functionalization of CQDs with 3-aminophenylboronic acid (3-APBA) was first executed via EDC/EHS coupling. B-cyclodextrin ( $\beta-C D)$ were then covalently bond with APBACQDs, in an alkaline environment, by the formation of cyclic boronic esters between cis-diols of $\beta-C D$ and boronic acid. Moreover, doxorubicin (DOX) was loaded into the previously prepared CQDs to create a multifunctional nanoplatform DOX- $\beta-C D / C Q D s$ for the controlled targeting, delivery, and release of the anti-cancer drug doxorubicin. Chen et al. [88] prepared nitrogen-doped CQDs (NCQDss) via an electrolytic method with graphite electrodes and ammonia aqueous solution as the electrolyte. After the synthesis, the N-CQDs were dispersed in water with the assistance of ultrasonication. Then, immobilization of horseradish peroxidase (HRP) was performed by adding NCQDs to the solution of HRP in PBS at pH 7.0 and stirring $(150 \mathrm{rpm})$ at $4{ }^{\circ} \mathrm{C}$ for $24 \mathrm{~h}$. Adsorption, covalent attachment, and entrapment were the proposed mechanisms for the immobilization of HRP onto N-CQDs surface, through covalent bonding, hydrogen bonding, and hydrophobic interaction. The near-surface amino and carboxyl groups of $\mathrm{HRP}$ can effectively interact with the carboxyl, aldehyde, and amino groups of N-CQDs by hydrogen bonding or amido bonds, whereas hydrophobic groups of N-CQDs and the hydrophobic domain of HRP can promote a hydrophobic interaction that further aided HRP adsorption. The obtained N-CQDs@HRP were revealed to promote biomass and pigment contents of Arabidopsis thaliana seedlings under $\mathrm{Pb}, \mathrm{Cd}$, and saline stress conditions, proving the enhanced effect of HRP when functionalized with N-CQDs.

\subsubsection{Functionalization with Polymers}

He et al. [89] have reported the synthesis of two cationic polymer-derived CQDs (Taea-CQDs and Cyclen-CQDs) by hydrothermal method. The polymers Pcyclen or Ptaea and citric acid were used as starting materials. Both Pcyclen and Ptaea had been previously prepared through an epoxide ring-opening polymerization, an effective synthetic approach that has the potential to boost high biological compatibility. The passivated CQDs emitted bright blue luminescence under UV light at $365 \mathrm{~nm}$ wavelength, in an excitation dependent emission manner. The CQDs presented a narrow FWHM, suggesting narrow size nanoparticles distribution. The average sizes of CQDs were measured as $1.8 \pm 0.4 \mathrm{~nm}$ for Taea-CQDs and $5.4 \pm 2 \mathrm{~nm}$ for Cyclen-CQDs. However, CQDs displayed a low QY value of $3.25 \%$ and $1.73 \%$ for Taea-CQDs and Cyclen-CQDs, respectively. They were then used as cell imaging agents for real-time detection of HeLa cell's DNA transfection process. Janus et al. [90] manufactured poly(L-lysine)-based CQDs via a microwave-assisted synthesis. Firstly, the starting material poly(L-lysine) was prepared by the mixture of L-lysine and propylene carbonate, which was then submitted to microwave irradiation for $120 \mathrm{~min}$ at a temperature of $240{ }^{\circ} \mathrm{C}$. Afterward, $35 \% \mathrm{H}_{2} \mathrm{SO}_{4}$ was added to the previously prepared mixture and once again submitted to microwave irradiation. The synthesized CQDs exhibited a $\mathrm{pH}$-dependent fluorescence emission, with a maximum QY inferior to $15 \%$. The CQDs were utilized to monitor various biomolecules and metal ions. Free radical removal activity was also evaluated. In 2019, Arsalani et al. [91] fabricated polyethylene glycol (PEG) passivated fluorescent CQDs (CQDs-PEG) via microwave-assisted synthesis, utilizing gelatin and PEG as starting materials. CQDs-PEG presented a QY of $34 \%$ and an excitation dependent emission behavior. The average size of CQDs-PEG was estimated to 
be $6 \mathrm{~nm}$. The as-prepared CQDs-PEG were afterward loaded with the drug methotrexate to develop an anticancer drug nanocarrier against MCF-7 cells. Li et al. [92] prepared polymer functionalized CQDs via the reflux method, using citric acid as a carbon source and Tris-HMA as a nitrogen source. After the CQDs synthesis and polymer preparation, the CQDs were functionalized with catechol-terminated hydrophilic poly(poly(ethylene glycol) methyl ether methacrylate (PPEGMA) or hydrophobic polystyrene (PS) by the mussel chemistry, obtaining CQDs@PEGMA and CQDs@PS, correspondently. The procedure relies on the principle that at room temperature, the mixing of reactants triggers the reaction while maintaining the inherent properties of the substrates. The Schiff base condensation/Michael addition reaction enhanced the optical and physical properties of bare CQDs through the polymer anchoring and PS that, being both hydrophobic, could grant hydrophobic features to otherwise hydrophilic CQDs, expanding their application range. The CQDs@PEGMA and CQDs@PS were later incorporated in a white LED.

\section{Purification/Separation}

Considering what has been mentioned previously about the influence that CQDs' chemical and physical characteristics have on their properties and interactions' potentialities, it is understandable that procedures that allow the purification or separation of different CQDs populations from the complex mixture that is formed during synthesis is one of the most important processes in CQDs production. However, although multiple synthesis methods have been detailed in the literature, the deficiency in purification methodologies is concerning. Among the methods described in the literature for the purification/separation of CQDs are dialysis, reversed-phase high performance liquid chromatography, electrophoresis, density gradient ultracentrifugation, $\mathrm{pH}$-controlled cloudpoint extraction technique, gel column size-exclusion chromatography, and others. The most utilized purification method for CQDs is, undoubtedly, dialysis. However, despite this, there are still no standards or guidelines either for the dialysis time or the molecular weight cut-off (MWCO) of the dialysis membrane, and other less utilized methods suffer from the same lack of information. Moreover, even though often purification methods are employed after CQDs synthesis, very few works particularize the conditions established for said purification. In the present paradigm of the CQDs research field, the attempt to utilize unpurified or inadequately purified CQDs to interpret reaction or formation mechanisms, and fluorescence emission generation mechanisms, leads to poor misinformation of data or warped data interpretation, with more questions raised than clarified.

\subsection{Dialysis}

Dialysis is the most used purification methodology employed. It relies on the unequal diffusion of small molecules or dissolved ions across the pores of semipermeable membranes, stemmed from the movement of substances from high concentration areas to low concentration areas, leading to separation.

In 2019, Chen et al. [93] have evaluated the appropriate time needed for efficient CQDs separation by dialysis resorting to HPLC. The CQDs were synthesized via a microwaveassisted method using citric acid as the sole precursor. The as-prepared CQDs displayed an excitation dependent emission behavior. Then, the decrease in the amount of residual synthesis by-products during the dialysis process was accompanied by HPLC. It was found that at least $120 \mathrm{~h}$ are required for the complete removal of the mentioned by-products from the CQDs solution. In fact, these monitoring studies allowed the authors to conclude about the very low yield of the synthesis that otherwise it would not be detected. Additionally, membranes with MWCOs inferior to $1 \mathrm{kDa}$ are prone to trap the by-products, leading to an inefficient purification. Thus, it is was concluded that many reported studies in the literature did not comply with the referred specifications, either by employing dialysis membranes with too small MWCO or by not performing the dialysis procedure for an adequate amount of time. It was also found that solutions of CQDs derived only from citric acid contained at least three kinds of CQDs, demonstrating that even synthesis carried 
out solely with one carbon source can originate complex CQDs solutions. Moreover, the attempt to interpret the chemical composition or optical properties of CQDs present in different fractions of the HPLC chromatogram without a suitable dialysis process only leads to uncertain conclusions.

\subsection{Reversed-Phase High Performance Liquid Chromatography}

Reversed-phase high performance liquid chromatography (RP-HPLC) is the most common HPLC separation technique and is based on the hydrophobic interactions between sample molecules and the ligands on the chromatographic support. In RP-HPLC, the polarity of the mobile phase is superior to the one presented by the stationary phase. Additionally, HPLC carries the advantage of allowing the obtaining of large quantities of fractioned CQDs, promoting the efficient characterization and understanding of optical properties, as well as incentivizing their usage on more feature-exigent applications [94].

Liu et al. [95] have isolated CQDs by column chromatography and a binary gradient elution via RP-HPLC. The CQDs were synthesized from citric acid and urea via a calcination reaction. The isolation revealed that the obtained CQDs sample was composed of several CQDs fractions containing disparate proportions of carboxyl and amine functional groups, which in turn directly affects CQDs fluorescence properties. It was also established that by simply varying the precursors ratios, different polarity CQDs could be prepared.

\subsection{Electrophoresis}

Electrophoresis can be described as the movement that leads to the separation of charged particles under the effect of an electric field. The mobility of the particles is conditioned by parameters such as particle charge, size, and shape, as well as the temperature in which the electrophoresis is performed.

Kokorina et al. [96] performed a gel electrophoresis separation of fluorophores created during CQDs synthesis and studied possible origins for their light emission. Following the premise that quite often, the bright fluorescence displayed by some CQDs might be not be completely related to the particles themselves, but to molecular fluorescent species such as 1,2,3,5-tet rahydro-5-oxo-imidazo[1, 2-a]pyridine-7-carboxylic acid (IPCA), the effect of the precursor ratio on the optical properties of CQDs and in the formation of fluorescent species has been evaluated. Therefore, a hydrothermal synthesis was carried out using citric acid (CA) and ethylenediamine (EDA). Results showed that gel electrophoresis is successfully capable of separating fractions presenting excitation-dependent and independent emission behavior and also provided a correlation between both fluorophore QY and optical properties, and the selected experimental conditions, such as the precursor employed.

\subsection{Density Gradient Ultracentrifugation}

Density gradient ultracentrifugation is based on the density differences of the suspended particles and the gradient of the medium, which is formed by layering solutions of different densities. During centrifugation, the particles may either ascend or descend, settling in the layer with a corresponding density. Generally, long-term centrifugation is needed, and the density slope of gradient media in the centrifuge tube affects the resolution, as shallower centrifuge tubes allow for a better resolution [97].

\subsection{Others}

In 2020, Beiraghi et al. [98] purified and fractioned CQDs using a pH-controlled cloud-point extraction (CPE) technique. The CQDs were prepared using citric acid as the sole precursor via a hydrothermal synthesis. Firstly, CQDs were separated from their precursors by two steps. Initially, CQDs were transferred to centrifuge tubes and had their $\mathrm{pH}$ adjusted to values ranging from 1 to 12 using either $\mathrm{HCl}$ or $\mathrm{NaOH}$. Later, Triton $\mathrm{X}-114$ solution was added to the tubes that were then transferred to a thermostatic water bath at $40{ }^{\circ} \mathrm{C}$, for $10 \mathrm{~min}$. The process of the aqueous and surfactant-rich phase separation was speeded by centrifugation for $10 \mathrm{~min}$ at $3000 \mathrm{rpm}$. The second step involved the 
addition of water to surfactant-rich phases, after their separation through decantation, and $\mathrm{pH}$ adjustment to 7 . Then, the CPE procedure was once again performed, and the supernatants obtained were collected. The fractioning of CQDs followed a similar experimental process and allowed the obtention of two fractions, namely, f1 and f4, in which the subscript refers to the $\mathrm{pH}$ values of aqueous phase. The fractionation was found to rely on the surface chemistry of the CQDs, a parameter that also has a significant effect on CQDs fluorescence emission. Uthirakumar et al. [99] developed a purification method alternative to dialysis, which allowed the isolation and recovery of over $80 \%$ of CQDs. The CQDs were synthesized by the reflux method using carbon black pigment dissolved in a mixture of $\mathrm{H}_{2} \mathrm{SO}_{4}$ and $\mathrm{HNO}_{3}$. The obtained CQDs had an average size of $2.6 \mathrm{~nm}$. The isolation was carried out using a water-immiscible organic solvent, $n$-butanol. After the dilution of the previously prepared CQDs with distilled water, $n$-butanol was added. Both immiscible layers were stirred together for a controlled period and then separated using a separating funnel. Then, the top CQDs rich organic layer was collected, and the bottom layer was washed with $n$-butanol for two more times. Afterwards, the collected organic layers were mixed and swiftly washed with water for the removal of the free acid and salts. Kokorina el al. [100] reported the fractionation of a CQDs mixture by gel column size-exclusion chromatography. The CQDs were manufactured by the hydrothermal method using dextran sulfate sodium salt (DSS) as the starting material. Then, the as-prepared CQDs were submitted to gel column size-exclusion chromatography, resulting in 48 CQDs fractions (each of $0.7 \mathrm{ml}$ ) that displayed distinct optical properties. The 48 isolated CQDs fractions were comprised of at least three types of CQDs. The first kind of CQDs showed maximum emission at $410-420 \mathrm{~nm}$, the second at $490 \mathrm{~nm}$, and the third at $530 \mathrm{~nm}$. Hinterberger et al. [101] have performed the purification of CQDs by column chromatography and have proposed a structural elucidation of the isolated CQDs. The CQDs were synthesized via hydrothermal method using citric acid (CA) and DL-cysteine, under different reaction conditions and reagent molar ratios. The purification of CQDs was achieved by employing a silica column with a water/acetonitrile (1:1) eluent. The isolated fractions were found to possess variable amounts of fluorescence emitting species, which was directly related to synthesis conditions employed, as well as the retention time. The obtained fractions contained free fluorophores 5-oxo-3,5-dihydro-2H-thiazolo [3,2-a] pyridine-3,7-dicarboxylic acid (TPDCA), fluorophores connected to CQDs surface and low-fluorescent carbon particles without connected fluorophores, and a higher number of free fluorophores was observed when the retention time was low. Moreover, harsher synthesis conditions appeared to lead to the destruction of free fluorophores, reducing the concentration of fluorescent CQDs. The highest QY value of 70\% was obtained using mild experimental conditions.

\section{Characterization Methods}

Just as important as purification/separation techniques, characterization methods are essential to assess CQDs' features. Despite a better understanding of CQDs' properties such as structure arrangement, morphology, chemical nature, and physical characteristics, much work remains to be done to completely elucidate CQDs' characteristics as a nanomaterial. Part of the challenge of such endeavor is steamed from the fact that CQDs exist as a complex mixture that embodies several distinct elements with disparate sizes and surface functional groups [102]. In this section, some of the most used characterization methods (represented in Figure 6) will be examined in a brief and yet elucidative way, providing a much-needed overview of the various techniques employed in CQDs characterization. For this review, we will focus on microscopic and spectroscopic methods, since they are the most practical for routine characterization and provide a large amount of valuable information about CQDs features. 


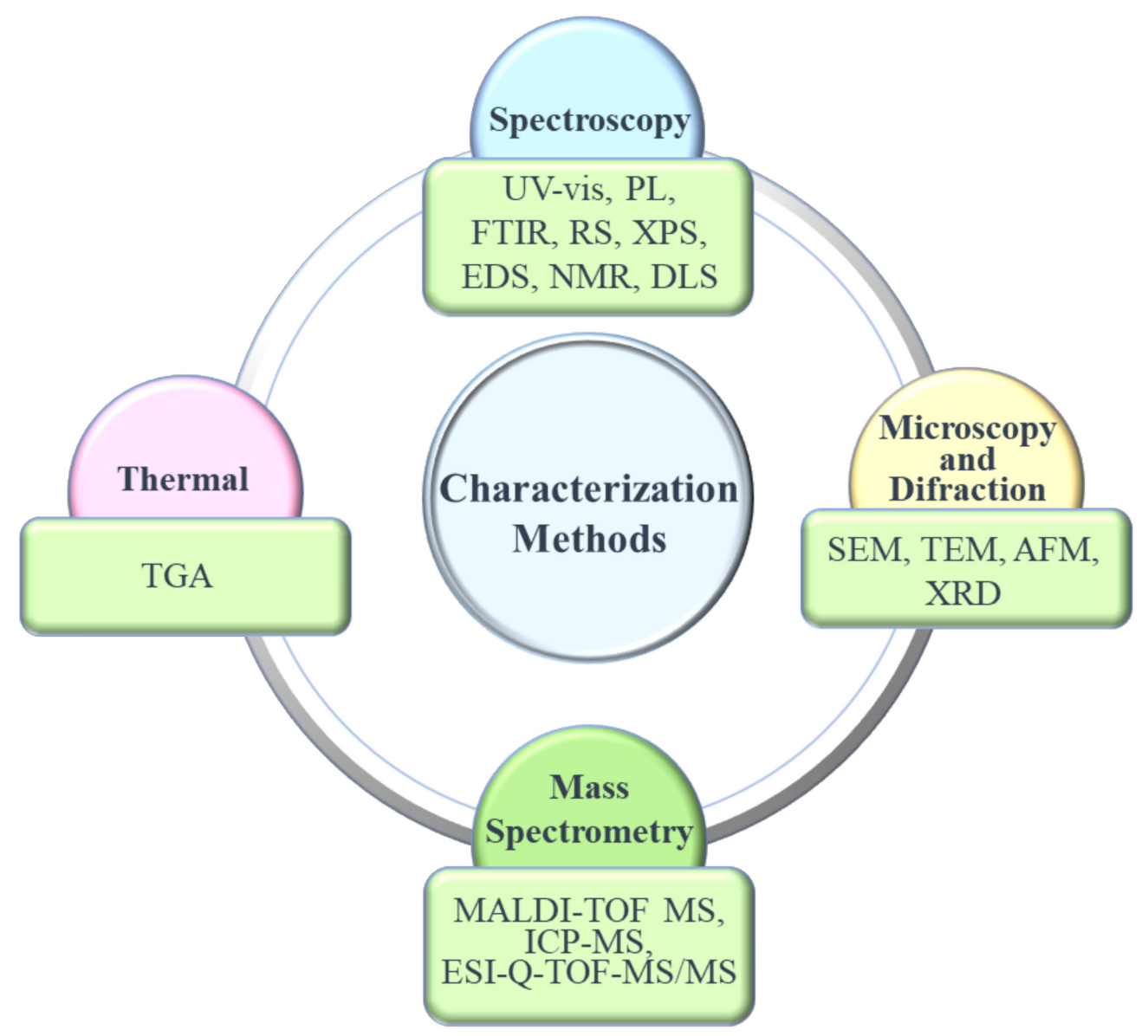

Figure 6. Diagram portraying common characterization methods of CQDs.

\subsection{Microscopy/Diffraction}

\subsubsection{Transmission and Scanning Electron Microscopies (TEM and SEM)}

TEM relies on the incidence of a highly energetic electron beam upon a very thin sample to image and analyze the structure of nanomaterials with an atomic-scale resolution. Electromagnetic lenses are utilized to focus the electrons, and the image is attained either on a fluorescent screen or recorded on film or digital camera. TEM is one the most employed techniques in the characterization of carbon nanomaterials, as it allows the distinction of similar-looking nanomaterials that, otherwise, might be confused when resorting to scanning electron microscopy [103]. SEM uses focused electron beams, focusing incidental electrons onto the sample, producing electron scattering triggered by the interaction between the electrons and the sample atoms [104]. TEM and SEM share several features, and both are capable of discerning particle agglomeration to assess if adequate particle dispersion was accomplished. However, TEM is preferred in situations where the particle size exceeds the resolution of SEM, as TEM possesses higher resolution power. Figure 7a-e contains examples of SEM and TEM images of CQDs. 

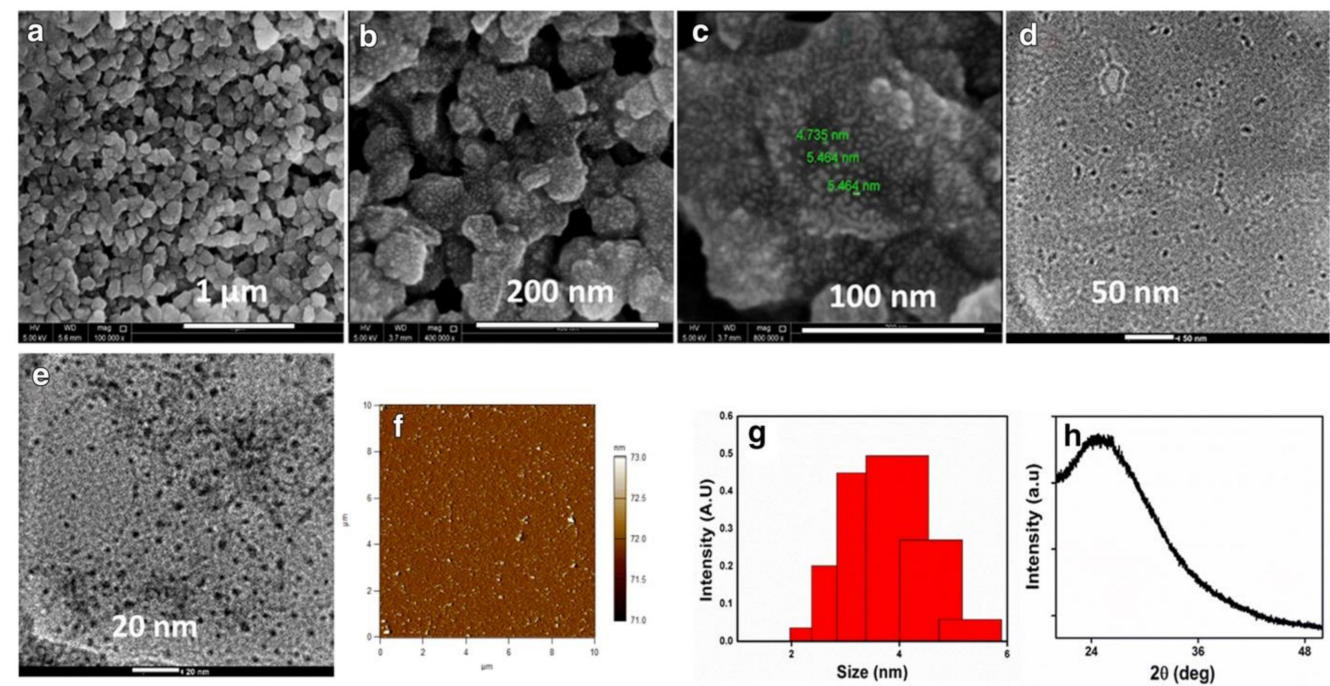

Figure 7. (a-c) SEM of CQDs; (d) and (e) TEM of CQDs; (f) CQDs size distribution; (h) XRD of CQDs. Reproduced with permission from ref. [105], published by Springer Open, 2020.

\subsubsection{Atomic Force Microscopy (AFM)}

AFM works based on raster-scanning a cantilever-tip ensemble excited at a fixed frequency over the sample surface, probing the generated interaction force with piconewton sensitivity. The oscillation amplitude of the sharp tip ensemble is employed as a feedback parameter during the imaging of the sample topography [106,107]. In comparison to both SEM and TEM techniques that generate two-dimensional CQDs images, AFM also supplies three-dimensional images of the CQDs (Figure 7f), allowing the obtaining of morphological information, as well as the estimation of CQDs size by the random assessing the height of a fixed number of CQDs [108].

\subsubsection{X-ray Diffraction (XRD)}

$\mathrm{XRD}$ is often used for the characterization of crystalline materials, and its working principle is that the interaction between X-rays and crystalline materials creates constructive interference that allows the identification of the materials based on their diffraction patterns. From the values of peak positions, areas, and FWHM, it is possible to calculate CQDs percentage crystallinity [109]. A representative example is depicted in Figure 7h.

\subsection{Spectroscopy}

\subsubsection{Ultraviolet-Visible (UV-vis) Spectroscopy}

UV-vis spectroscopy of CQDs can be used to aid in the determination of CQDs surface functional groups, by clarifying interactions between these groups, particularly conjugation. For example, an absorption peak at $275 \mathrm{~nm}$ corresponds to $\mathrm{n} \rightarrow \pi^{*}$ transition associated to $\mathrm{C}=\mathrm{O}$ bond, and a peak at $225 \mathrm{~nm}$ is caused by the $\pi \rightarrow \pi^{*}$ transition related with aromatic $\mathrm{sp}^{2}$ domains [110].

\subsubsection{Photoluminescence (PL) Spectroscopy}

The PL spectra of CQDs not only permit the assessment of the uniformity of CQDs chemical characteristics, as a large bandwidth emission is often related to mixed populations of CQDs, but also determine if the fluorescence emission is excitation wavelength dependent or not. Examples of excitation dependent or independent behavior can be observed in Figure 8. This characterization is very important as it allows for a better understanding of the possible fluorescence origin, as the intervention of surface states seems to generate excitation dependent emission behavior, and an independent behavior appears to be correlated with passivated surface states $[7,111]$. Additionally, the combination of 
information collected through UV-vis and PL spectroscopy can be used to assess the QY value of CQDs [112].
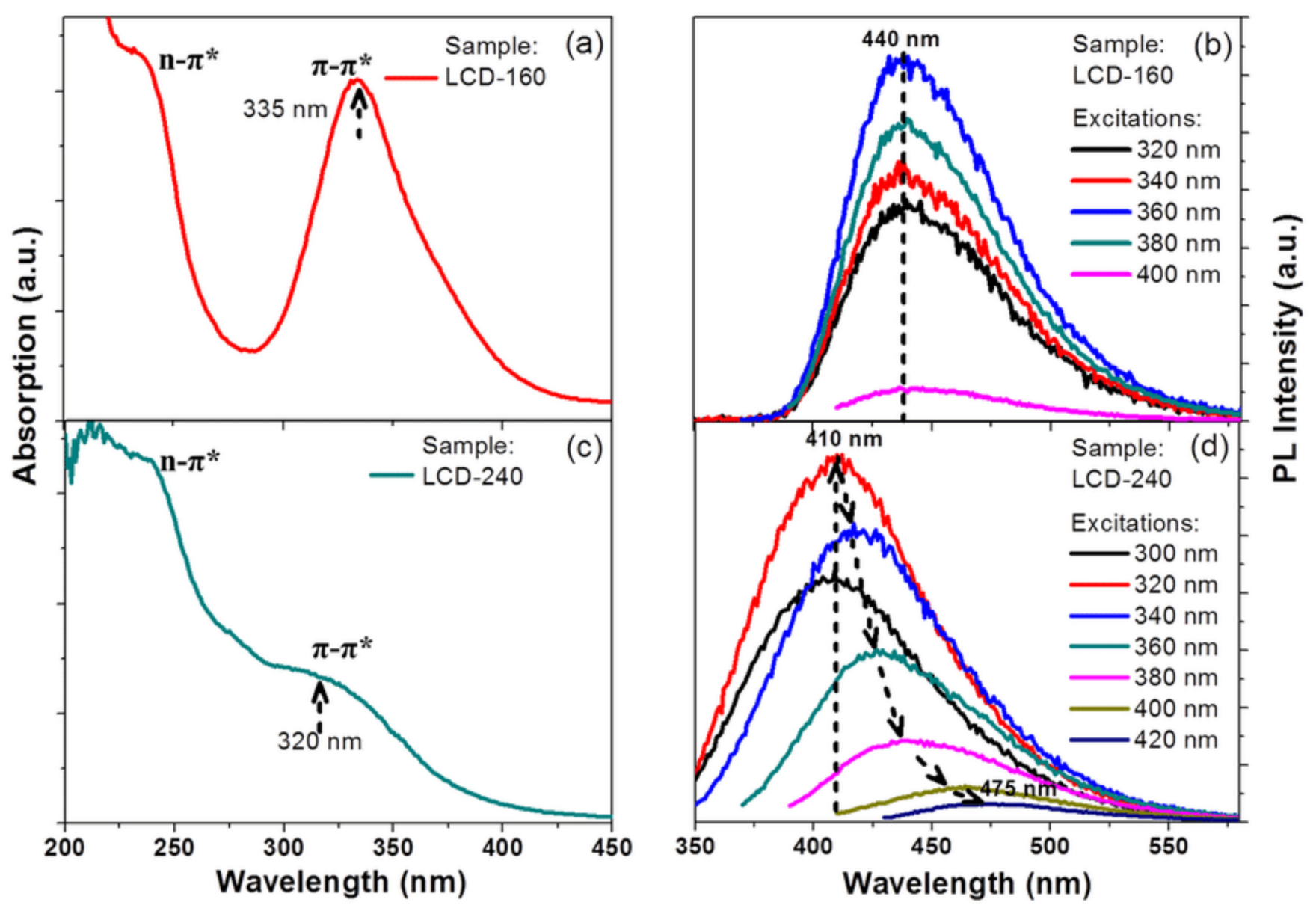

Figure 8. (a) and (c) UV-Vis absorption spectra of CQDs obtained at reaction temperature 60 and $240{ }^{\circ} \mathrm{C}$; (b) and (d) PL spectra demonstrating independent and dependent behavior. Reproduced with permission from ref. [111], published by Scientific Reports, 2014.

\subsubsection{Fourier-Transform Infrared Spectroscopy (FTIR)}

FTIR is one of the gold-standards in the determination of the functional groups, as it allows their distinction based on the vibration of interatomic bonds. Thus, absorption around the $3210-3640 \mathrm{~cm}^{-1}$ region can be ascribed to $\mathrm{O}-\mathrm{H}$, primary amines generate absorption around the $1580-1660 \mathrm{~cm}^{-1}$ region, and peaks at $1690-1760 \mathrm{~cm}^{-1}$ that are associated with absorption at 1080-1300 indicate the presence of carboxylic acid functional groups [113]. As hydroxyl, carboxyl, and amine functional groups tend to predominate in different proportions in CQDs surface, the usage of FTIR is an advantage in their characterization. In Figure 9 is depicted a FTIR spectra of previously fractioned CQDs, demonstrating that a single synthesis originates several CQDs populations. 


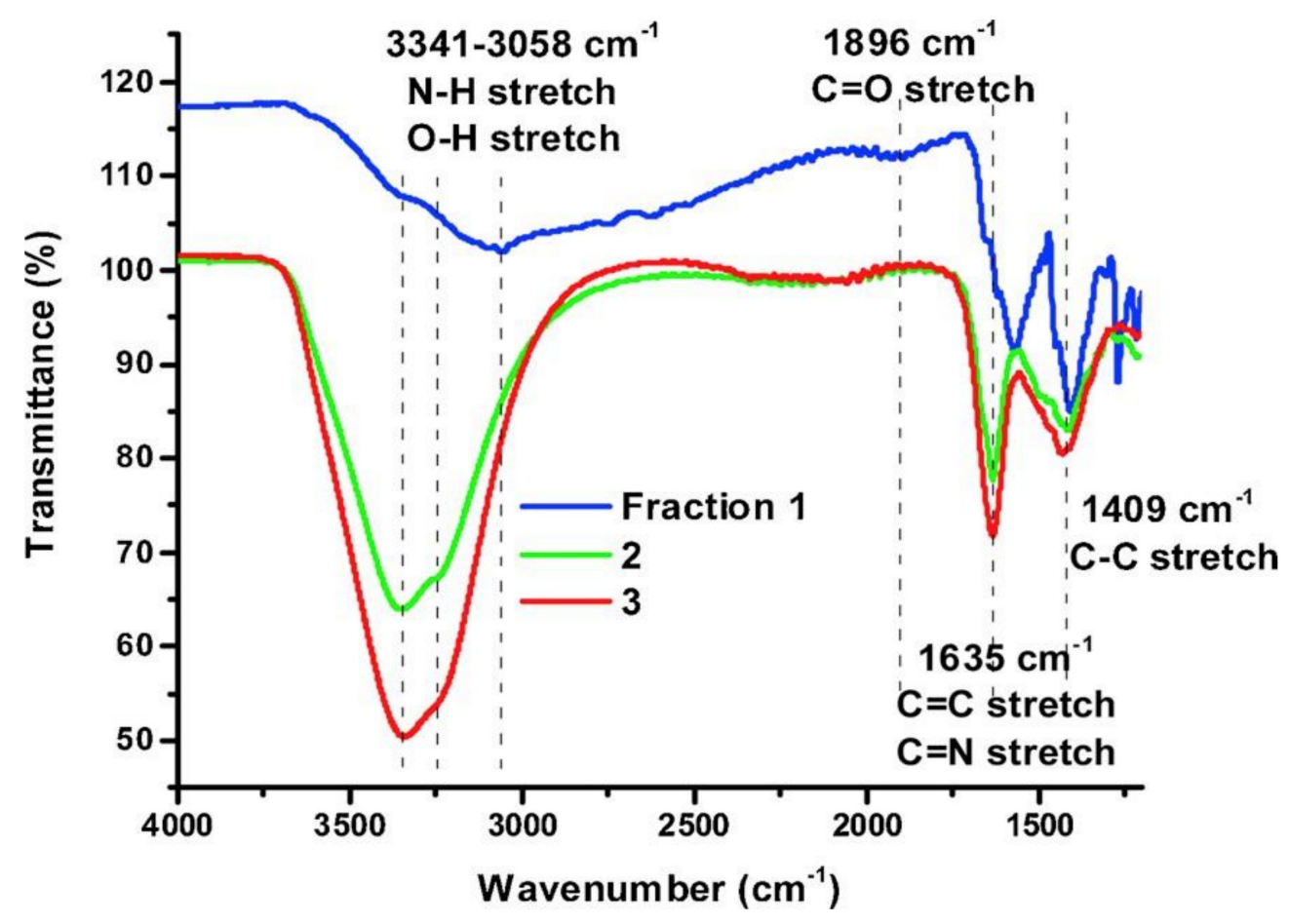

Figure 9. FTIR spectra of three CQDs fractions obtained from the same synthesis. Reprinted from ref. [114], with permission from Elsevier.

\subsubsection{Raman Spectroscopy (RS)}

Raman spectroscopy is a commonly employed as non-invasive and non-destructive method for CQDs characterization. The $\mathrm{G}$ band (graphitic band) is related to the $\mathrm{E}_{2 \mathrm{~g}}$ mode of graphite and is associated with the vibration of $\mathrm{sp}^{2}$ carbon atoms in a two-dimensional hexagonal lattice, while the $\mathrm{D}$ band is generated by the vibrations of dangling bonds on carbon atoms in the termination plane of either disordered graphite or glassy carbon. By determining the ratio of the intensities of the disordered $D$ band and crystalline $G$ band $(\mathrm{D} / \mathrm{G})$, it is possible to evaluate the purity (degree of disorder or graphitization) of the studied nanomaterial [115].

\subsubsection{X-ray Photoelectron Spectroscopy (XPS)}

XPS is a surface analysis technique particularly relevant as it provides information about the electronic state of the elements, elemental analysis of the outermost atomic layers, and surface features of a given nanomaterial. XPS relies on the ejection of photoelectrons of inner shells and the measurement of their kinetic energy, which is caused by the irradiation of the sample with X-ray photons. It is capable of detecting all elements except for hydrogen, and often does not present enough spatial resolution to study individual nanoparticles [116].

\subsubsection{Energy Dispersive Spectroscopy (EDS)}

EDS is a useful method when the sample size is small and provides qualitative and quantitative information on the elemental composition of the examined material. After the surface atoms are excited by an electron beam, the emission of X-rays with characteristic wavelengths is analyzed by energy dispersive detectors that identify the atomic structure of the sample [117]. EDS can also be used to monitor CQDs purity, as impurities and unwanted elements can be easily detected. 


\section{Applications}

Considering the described features and optical properties, CQDs have been employed in a wide array of applications ranging from electrochemical applications, wastewater treatment, bioimaging, and biotechnology, as well as chemical sensing and optoelectronic devices like LEDs. A small number of the possible applications are represented in Figure 10.

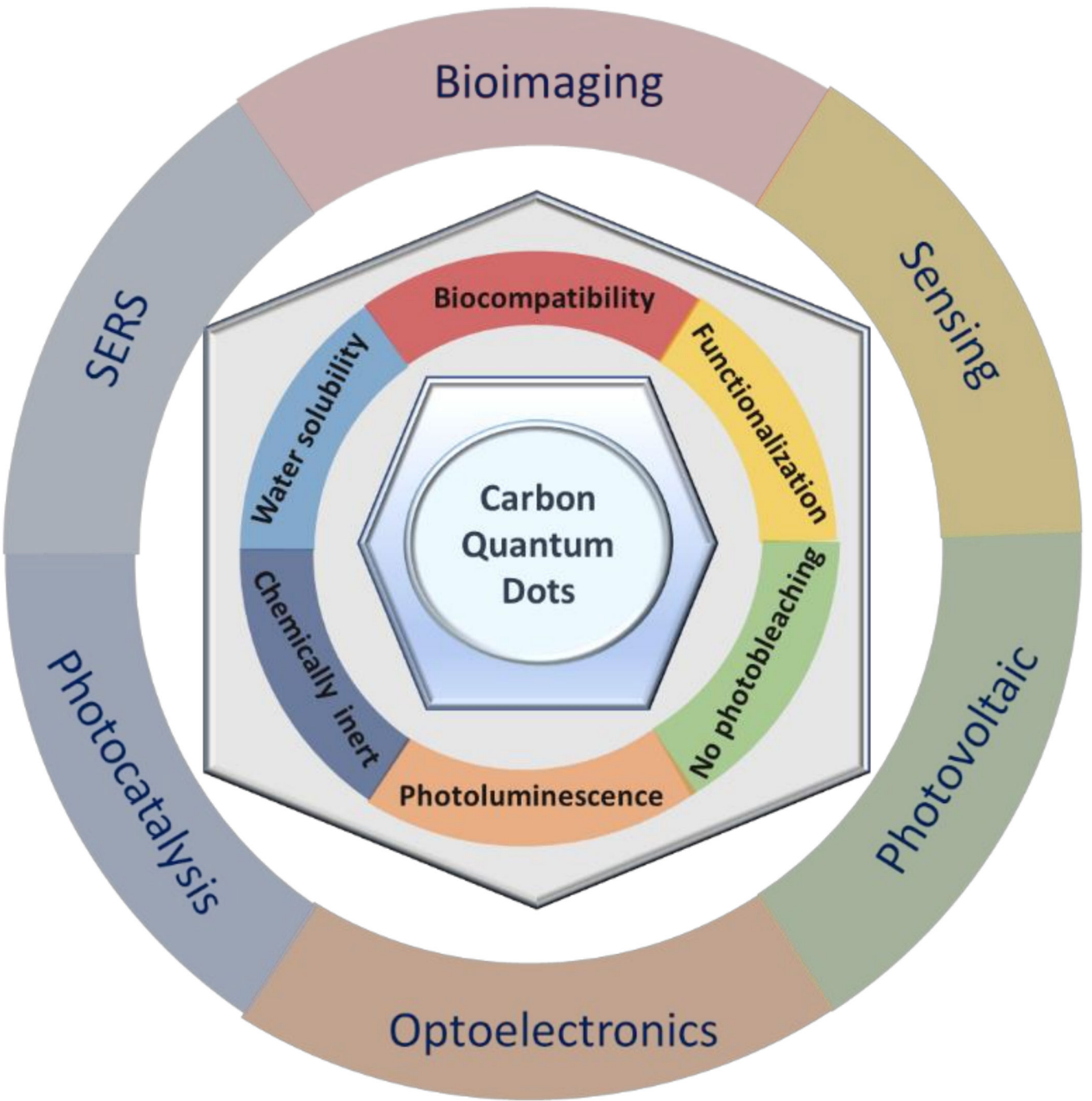

Figure 10. Schematic correlation between CQDs' physical and chemical properties and possible applications in various fields.

Additionally, in Tables 2-7, one can find a literature review focused on the latest state of the art (between 2018 and 2020) of CQDs in terms of their diverse applications, to provide the readers with the present potential of CQDs in fields such as biomedical (Table 2), chemical sensing (Table 3), optoelectronics (Table 4), photocatalysis (Table 5), antimicrobial and antiviral (Table 6), and finally, other applications (Table 7). These tables include valuable information such as details of the synthesis methodologies, namely the starting materials employed and process conditions, the characterization and purification methods exploited and their impact in the final quality of CQDs, and the regular surface modifications and heteroatom doping used often to boost the target application of CQDs. 
Table 3. Summarized examples of carbon quantum dots used for biomedical applications.

\begin{tabular}{|c|c|c|c|c|c|c|c|c|c|c|c|}
\hline Application & Target & Ligands & Receptor & $\begin{array}{l}\text { CQDs Synthesis } \\
\text { Method }\end{array}$ & Precursors & $\begin{array}{c}\text { Reaction } \\
\text { Conditions }\end{array}$ & $\begin{array}{l}\text { Modifications and } \\
\text { Functionalization }\end{array}$ & Purification & $\begin{array}{c}\text { Average } \\
\text { Size (nm) }\end{array}$ & QY (\%) & Ref. \\
\hline Bioimaging & HeLa cells & $\mathrm{n} / \mathrm{a}$ & $\mathrm{n} / \mathrm{a}$ & Hydrothermal & $\begin{array}{c}\text { Citric acid } \\
\text { ethylenediamine } \\
\text { alkali lignin }\end{array}$ & $150^{\circ} \mathrm{C}, 4 \mathrm{~h}$ & Lignin hybridized & $\begin{array}{c}\text { Dialysis } \\
\text { (3500 Da, } 2 \text { days) }\end{array}$ & $<10$ & 43 & [30] \\
\hline $\begin{array}{l}\text { Growth } \\
\text { promotion }\end{array}$ & Mung bean plant & $\mathrm{n} / \mathrm{a}$ & $\mathrm{n} / \mathrm{a}$ & Hydrothermal & $\begin{array}{l}\text { Citric acid } \\
L \text {-Cysteine } \\
D \text {-Cysteine }\end{array}$ & $180^{\circ} \mathrm{C}, 1.5 \mathrm{~h}$ & $\begin{array}{l}\text { N, S-doping } \\
\text { Chirality }\end{array}$ & $\begin{array}{c}\text { Dialysis } \\
\text { (500-1000 Da, } \\
5 \text { days) }\end{array}$ & 6 & $\begin{array}{l}\text { L-CDs: } 31 \\
\text { D-CDs: } 33\end{array}$ & [32] \\
\hline $\begin{array}{l}\text { Bioimaging } \\
\text { Antitumor } \\
\text { therapy }\end{array}$ & $\begin{array}{l}\text { HeLa cells (in vivo } \\
\text { and in vitro) }\end{array}$ & Gallic acid & $\mathrm{n} / \mathrm{a}$ & Microwave-assisted & $\begin{array}{c}\text { Gallic acid } \\
\text { Citric acid } \\
\text { Ethane diamine }\end{array}$ & $700 \mathrm{~W}, 3 \mathrm{~min}$ & Gallic acid hybridized & $\begin{array}{c}\text { Centrifugation } \\
(10,000 \times g \mathrm{rpm}, \\
\text { time } 10 \mathrm{~min}) \\
\text { Dialysis }(500 \mathrm{Da}, \\
72 \mathrm{~h})\end{array}$ & $2-4$ & 25 & {$[37]$} \\
\hline Bioimaging & $\begin{array}{l}\text { Streptococcus sp. } \\
\text { and Klebsiella } \\
\text { pneumoniae }\end{array}$ & $\mathrm{n} / \mathrm{a}$ & $\mathrm{n} / \mathrm{a}$ & $\begin{array}{l}\text { Mechanical and } \\
\text { ultrasonic millings }\end{array}$ & Curcumin (BOSF) & $\begin{array}{c}\text { Pulsed mode } \\
(750 \mathrm{~W}, \\
20 \mathrm{kHz}) \\
\text { intensity of } \\
30 \mathrm{~W} / \mathrm{cm}^{2} \\
20 \mathrm{~min}\end{array}$ & $\mathrm{n} / \mathrm{a}$ & $\mathrm{n} / \mathrm{a}$ & 13.7 & $\mathrm{n} / \mathrm{a}$ & [26] \\
\hline Bioimaging & $\begin{array}{l}\text { HeLa cells, L02 } \\
\text { cells, and } \\
\text { macrophage cells }\end{array}$ & $\mathrm{n} / \mathrm{a}$ & $\mathrm{n} / \mathrm{a}$ & Pulsed laser ablation & Platanus biomass & $\begin{array}{c}\text { Repetition } \\
\text { rate of } 10 \mathrm{~Hz} \text {, } \\
\text { wavelength of } \\
106 \mathrm{~nm}, \\
20 \mathrm{~mJ}, 3-6 \mathrm{~ns}, \\
30 \mathrm{~min} \\
\end{array}$ & $\mathrm{~N}$-doping & $\begin{array}{c}\text { Centrifugation } \\
(10,000 \times g \text { rpm, } \\
\text { time } \mathrm{n} / \mathrm{a}) \times 5\end{array}$ & 8 & 32.4 & [50] \\
\hline \multirow{3}{*}{ Bioimaging } & \multirow{3}{*}{$\begin{array}{l}\text { E. coli, Aspergillus } \\
\text { aculeatus and } \\
\text { Fomitopsis sp. }\end{array}$} & \multirow{3}{*}{$\mathrm{n} / \mathrm{a}$} & \multirow{3}{*}{$\mathrm{n} / \mathrm{a}$} & \multirow{3}{*}{ Hydrothermal } & \multirow{3}{*}{ Manilkara zapota fruits } & $\begin{array}{c}\text { blue C-dots: } \\
10{ }^{\circ} \mathrm{C}, 60 \mathrm{~min}\end{array}$ & \multirow{3}{*}{$\mathrm{n} / \mathrm{a}$} & \multirow{3}{*}{$\begin{array}{c}\text { Dialysis } \\
(12,000-14,000 \\
\text { Da, } 24 \mathrm{~h})\end{array}$} & 1.9 & 5.7 & \multirow{3}{*}{52} \\
\hline & & & & & & $\begin{array}{l}\text { green C-dots: } \\
80^{\circ} \mathrm{C}, 30 \mathrm{~min}\end{array}$ & & & 2.9 & 7.9 & \\
\hline & & & & & & $\begin{array}{l}\text { yellow C-dots: } \\
80^{\circ} \mathrm{C}, 15 \mathrm{~min}\end{array}$ & & & 4.5 & 5.2 & \\
\hline Bioimaging & SMMC7721 cells & $\mathrm{n} / \mathrm{a}$ & $\mathrm{n} / \mathrm{a}$ & Hydrothermal & $\begin{array}{c}p \text {-Phenylenediamine } \\
\text { Ammonia }\end{array}$ & $200^{\circ} \mathrm{C}, 8 \mathrm{~h}$ & $\mathrm{~N}$-doping & $\begin{array}{c}\text { Dialysis } \\
\text { (500-1000 Da, } \\
3 \text { days) }\end{array}$ & 3.2 & 13.2 & [57] \\
\hline Bioimaging & HEp-2 cells & $\mathrm{n} / \mathrm{a}$ & $\mathrm{n} / \mathrm{a}$ & Hydrothermal & $\begin{array}{l}\text { Citric acid } \\
\text { Methionine }\end{array}$ & $200^{\circ} \mathrm{C}, 3 \mathrm{~h}$ & N, S-doping & $\begin{array}{c}\text { Centrifugation } \\
(12,000 \times g \mathrm{rpm}, \\
15 \mathrm{~min}) \\
\text { Dialysis }(500 \mathrm{Da}, \\
12 \mathrm{~h})\end{array}$ & 5 & 13.8 & [67] \\
\hline
\end{tabular}


Table 3. Cont.

\begin{tabular}{|c|c|c|c|c|c|c|c|c|c|c|c|}
\hline Application & Target & Ligands & Receptor & $\begin{array}{l}\text { CQDs Synthesis } \\
\text { Method }\end{array}$ & Precursors & $\begin{array}{c}\text { Reaction } \\
\text { Conditions }\end{array}$ & $\begin{array}{l}\text { Modifications and } \\
\text { Functionalization }\end{array}$ & Purification & $\begin{array}{c}\text { Average } \\
\text { Size (nm) }\end{array}$ & QY (\%) & Ref. \\
\hline $\begin{array}{l}\text { Cellular ATP } \\
\text { monitoring }\end{array}$ & T24 cells & $\mathrm{n} / \mathrm{a}$ & $\mathrm{n} / \mathrm{a}$ & Hydrothermal & $\begin{array}{l}L \text {-Cysteine } \\
D \text {-Cysteine }\end{array}$ & $60^{\circ} \mathrm{C}, 24 \mathrm{~h}$ & $\begin{array}{l}\text { N, S-doping } \\
\text { Chirality }\end{array}$ & $\begin{array}{c}\text { Dialysis } \\
(\text { MWCO n/a, } \\
\text { time n/a) }\end{array}$ & $5-7$ & 41.26 & [68] \\
\hline $\begin{array}{l}\text { Bioimaging } \\
\text { Ion detection }\end{array}$ & MCF-7 cells & $\mathrm{n} / \mathrm{a}$ & $\mathrm{n} / \mathrm{a}$ & Microwave-assisted & $\begin{array}{l}\text { 1,6-Hexanediamine } \\
\text { dihydrochloride } \\
\text { Dimethylsulfoxide }\end{array}$ & $180^{\circ} \mathrm{C}, 35 \mathrm{~min}$ & N, S-doping & $\begin{array}{c}\text { Filtration with } \\
\text { filter membrane } \\
(0.22 \mu \mathrm{m}) \\
\text { Dialysis }(500 \mathrm{Da} \\
\text { membrane,36 h) }\end{array}$ & 4.35 & 24 & [69] \\
\hline Bioimaging & $\begin{array}{l}\text { HeLa and MCF-7 } \\
\text { cells }\end{array}$ & $\mathrm{n} / \mathrm{a}$ & $\mathrm{n} / \mathrm{a}$ & Hydrothermal & $\begin{array}{c}\text { 3- } \\
\text { Aminobenzeneboronic } \\
\text { acid } \\
\text { 1,2-Ethylenediamine }\end{array}$ & $160^{\circ} \mathrm{C}, 7 \mathrm{~h}$ & N, B-doping & $\mathrm{n} / \mathrm{a}$ & 2.61 & 47.3 & [72] \\
\hline $\begin{array}{l}\text { Bioimaging } \\
\text { Bacteria } \\
\text { identification }\end{array}$ & $\begin{array}{c}\text { Escherichia coli (E. } \\
\text { coli), Desulfovibrio } \\
\text { desulfuricans (D. } \\
\text { desulfuricans), } \\
\text { Staphylococcus } \\
\text { sciuri (S. sciuri), } \\
\text { Listeria } \\
\text { monocytogenes (L. } \\
\text { monocytogenes), } \\
\text { Staphylococcus } \\
\text { aureus (S. aureus) } \\
\text { and Pseudomonas } \\
\text { aeruginosa (P. } \\
\text { aeruginosa) }\end{array}$ & $\begin{array}{c}\text { 3- } \\
\text { Aminophenylboronic } \\
\text { acid/vancomycin } \\
\text { hydrochlo- } \\
\text { ride/polymyxin B } \\
\text { sulfate }\end{array}$ & $\begin{array}{l}\text { cis-diol/(D)- } \\
\text { Ala-(D)-Ala } \\
\text { peptide/LPS }\end{array}$ & Hydrothermal & $\begin{array}{l}\text { Ammonium citrate } \\
\text { dibasic } \\
\text { 3-Aminophenylboronic } \\
\text { acid/vancomycin } \\
\text { hydrochlo- } \\
\text { ride/polymyxin B } \\
\text { sulfate }\end{array}$ & $180^{\circ} \mathrm{C}, 4 \mathrm{~h}$ & $\begin{array}{l}\text { 3-Aminophenylboronic } \\
\text { acid/vancomycin } \\
\text { hydrochlo- } \\
\text { ride/polymyxin B } \\
\text { sulfate hybridized }\end{array}$ & $\begin{array}{c}\text { Centrifugation } \\
(10,000 \times g \mathrm{rpm}, \\
15 \mathrm{~min}) \\
\text { Dialysis }(1000 \\
\text { Da, overnight) }\end{array}$ & $3-6$ & $\mathrm{n} / \mathrm{a}$ & {$[118$} \\
\hline $\begin{array}{l}\text { Intracellular } \mathrm{pH} \\
\text { imaging }\end{array}$ & HepG2 cells & $\mathrm{n} / \mathrm{a}$ & $\mathrm{n} / \mathrm{a}$ & Hydrothermal & $\begin{array}{c}\text { Quercetin } \\
\text { Ethylenediamine }\end{array}$ & $200^{\circ} \mathrm{C}, 12 \mathrm{~h}$ & $\mathrm{~N}$-doping & $\begin{array}{c}\text { Filtration with } \\
\text { filter membrane } \\
\quad(0.22 \mu \mathrm{m}) \\
\text { Silica gel column } \\
\text { chromatography } \\
(\mathrm{CH} 2 \mathrm{Cl} 2 / \mathrm{MeOH} \\
(\mathrm{V} / \mathrm{V}, 20 / 1))\end{array}$ & 2.7 & 13.4 & {$[119$} \\
\hline Bioimaging & HUVEC cells & $\mathrm{n} / \mathrm{a}$ & $\mathrm{n} / \mathrm{a}$ & Solvothermal & $\begin{array}{l}m \text {-Phenylenediamine } \\
\text { Tobias acid }\end{array}$ & $200^{\circ} \mathrm{C}, 10 \mathrm{~h}$ & N, S-doping & $\begin{array}{c}\text { Centrifugation } \\
(10,000 \times \mathrm{g} \mathrm{rpm}, \\
10 \mathrm{~min} .) \\
\text { Filtration with } \\
\text { filter membrane } \\
(0.22 \mu \mathrm{m})\end{array}$ & 2.59 & 37.2 & {$[120$} \\
\hline
\end{tabular}


Table 3. Cont.

\begin{tabular}{|c|c|c|c|c|c|c|c|c|c|c|c|}
\hline Application & Target & Ligands & Receptor & $\begin{array}{l}\text { CQDs Synthesis } \\
\text { Method }\end{array}$ & Precursors & $\begin{array}{c}\text { Reaction } \\
\text { Conditions }\end{array}$ & $\begin{array}{l}\text { Modifications and } \\
\text { Functionalization }\end{array}$ & Purification & $\begin{array}{c}\text { Average } \\
\text { Size (nm) }\end{array}$ & QY (\%) & Ref. \\
\hline $\begin{array}{l}\text { Cell polarity } \\
\text { imaging }\end{array}$ & HepG2 cells & $\mathrm{n} / \mathrm{a}$ & $\mathrm{n} / \mathrm{a}$ & Hydrothermal & $p$-Phenylenediamine & $200^{\circ} \mathrm{C}, 12 \mathrm{~h}$ & $\mathrm{~N}$-doping & $\begin{array}{c}\text { Centrifugation } \\
\text { (6577× } 8 \\
15 \text { min) } \\
\text { Silica gel column } \\
\text { chromatography } \\
\text { (EtOH/Ethyl } \\
\text { acetate) }\end{array}$ & 5 & $\begin{array}{l}3.40 \text { (in } \\
\text { water) }\end{array}$ & [121] \\
\hline $\begin{array}{l}\text { Drug delivery } \\
\text { Bioimaging }\end{array}$ & HO-8910 cells & Doxorubicin & $\mathrm{n} / \mathrm{a}$ & Carbonization & $\begin{array}{l}\text { Sodium citrate } \\
\text { dehydrate } \\
\text { Urea }\end{array}$ & $200^{\circ} \mathrm{C}, 1 \mathrm{~h}$ & $\begin{array}{c}\text { N, S-doping } \\
\begin{array}{c}\text { Conjugation with } \\
\text { doxorubicin }\end{array}\end{array}$ & $\begin{array}{c}\text { Centrifugation } \\
(10,000 \times \mathrm{g} \mathrm{rpm}, \\
10 \mathrm{~min}, 3 \times) \\
\text { Dialysis } \\
(1000 \mathrm{Da}, 24 \mathrm{~h})\end{array}$ & 2.75 & 93 & [122] \\
\hline $\begin{array}{c}\text { Drug } \\
\text { delivery } \\
\text { Bioimaging }\end{array}$ & $4 \mathrm{~T} 1$ cells & Hyaluronic acid & CD44 & Hydrothermal & $\begin{array}{l}\text { Citric acid } \\
\text { Branched-PEI }\end{array}$ & $180^{\circ} \mathrm{C}, 1 \mathrm{~h}$ & $\begin{array}{c}\text { Hyaluronic } \\
\text { acid-modified } \\
\text { Conjugation with } \\
\text { doxorubicin }\end{array}$ & $\begin{array}{c}\text { Ultrafilytration } \\
\text { (MWCO: 50,000), } \\
4000 \mathrm{rpm}, \\
20 \mathrm{~min}, 4 \times\end{array}$ & 10 & $\mathrm{n} / \mathrm{a}$ & [123] \\
\hline $\begin{array}{l}\text { Drug delivery } \\
\text { Bioimaging }\end{array}$ & MGC-803 cells & Hyaluronic acid & CD44 & Hydrothermal & $\begin{array}{c}\text { Glucose } \\
\text { Glycol + PEI }\end{array}$ & $\begin{array}{c}180^{\circ} \mathrm{C}, 3 \mathrm{~h}+ \\
80^{\circ} \mathrm{C}, 3 \mathrm{~h}\end{array}$ & $\begin{array}{c}\text { Hyaluronic } \\
\text { acid-modified } \\
\text { Conjugation with } \\
\text { heparin }\end{array}$ & $\begin{array}{c}\text { Filtration with } \\
\text { filter membrane } \\
(0.22 \mu \mathrm{m}) \\
\text { Centrifugation } \\
(10,000 \times \mathrm{g} \mathrm{rpm} \\
20 \mathrm{~min})\end{array}$ & 3.9 & $\mathrm{n} / \mathrm{a}$ & [124] \\
\hline $\begin{array}{l}\text { Gene therapy } \\
\text { Bioimaging }\end{array}$ & BT-474 cells & HER3 siRNA & HER3 & Hydrothermal & $\begin{array}{c}\text { Citric acid } \\
\text { monohydrate } \\
\text { Ethylenediamine + } \\
\text { Branched } \\
\text { Polyetherimide }\end{array}$ & $200^{\circ} \mathrm{C}, 4 \mathrm{~h}$ & $\begin{array}{l}\text { Branched PEI } \\
\text {-functionalized } \\
\text { N-doping }\end{array}$ & $\begin{array}{c}\text { Centrifugation } \\
(13,000 \times \mathrm{grpm}, \\
20 \mathrm{~min}) \\
\text { Dialysis } \\
\text { (1000 Da, } 96 \mathrm{~h})\end{array}$ & 5.5 & $\mathrm{n} / \mathrm{a}$ & [126] \\
\hline $\begin{array}{l}\text { Bone } \\
\text { regeneration } \\
\text { promotion }\end{array}$ & Pre-osteoblast cells & $\mathrm{n} / \mathrm{a}$ & $\mathrm{n} / \mathrm{a}$ & Microwave-assisted & $\begin{array}{c}\text { Ascorbic acid } \\
\text { PEI }\end{array}$ & $450 \mathrm{~W}, 5 \mathrm{~min}$ & Polymer passivation & $\begin{array}{c}\text { Centrifugation } \\
(12,000 \times \mathrm{g} \mathrm{rpm}, \\
15 \mathrm{~min}) \\
\text { Filtration with } \\
\text { filter membrane } \\
(0.22 \mu \mathrm{m})\end{array}$ & $2-3$ & $\mathrm{n} / \mathrm{a}$ & [127] \\
\hline
\end{tabular}


Table 3. Cont.

\begin{tabular}{|c|c|c|c|c|c|c|c|c|c|c|c|}
\hline Application & Target & Ligands & Receptor & $\begin{array}{l}\text { CQDs Synthesis } \\
\text { Method }\end{array}$ & Precursors & $\begin{array}{c}\text { Reaction } \\
\text { Conditions }\end{array}$ & $\begin{array}{l}\text { Modifications and } \\
\text { Functionalization }\end{array}$ & Purification & $\begin{array}{c}\text { Average } \\
\text { Size (nm) }\end{array}$ & QY (\%) & Ref. \\
\hline $\begin{array}{c}\text { Modulation of } \\
\text { amyloid beta } \\
\text { fibrillation and } \\
\text { toxicity } \\
\text { Bioimaging }\end{array}$ & SH-SHSY5Y cells & $\mathrm{n} / \mathrm{a}$ & $A \beta 42$ & Hydrothermal & $\begin{array}{l}\text { L-lysine } \\
\text { D-lysine }\end{array}$ & $170^{\circ} \mathrm{C}, 2 \mathrm{~h}$ & Chirality & $\begin{array}{c}\text { Dialysis } \\
\text { (2000 Da, } 24 \text { h) }\end{array}$ & 3.9 & $\mathrm{n} / \mathrm{a}$ & {$[128$} \\
\hline $\begin{array}{l}\text { Photosynthesis } \\
\text { enhancement } \\
\text { (growth } \\
\text { stimulation) }\end{array}$ & $\begin{array}{l}\text { Chloroplasts } \\
\text { (in vivo and } \\
\text { in vitro) }\end{array}$ & $\mathrm{n} / \mathrm{a}$ & $\mathrm{n} / \mathrm{a}$ & Microwave-assisted & $\begin{array}{l}\text { Glutathione } \\
\text { Formamide }\end{array}$ & $800 \mathrm{~W}, 3 \mathrm{~min}$ & N, S-doping & $\begin{array}{c}\text { Centrifugation } \\
(10,000 \times g \text { rpm, } \\
5 \mathrm{~min}) \\
\text { Dialysis } \\
(3500 \text { Da, time } \\
\text { n/a) }\end{array}$ & 3.8 & 18.5 & [40] \\
\hline $\begin{array}{l}\text { Gene therapy } \\
\text { Bioimaging }\end{array}$ & A549 cells & $\mathrm{n} / \mathrm{a}$ & $\mathrm{n} / \mathrm{a}$ & Solvothermal & PEI $600 \mathrm{Da}$ & $180^{\circ} \mathrm{C}, 5 \mathrm{~h}$ & $\begin{array}{l}\text { functionalization with } \\
\text { hydrophobic chains } \\
\text { with different degrees } \\
\text { of substitution }\end{array}$ & $\begin{array}{c}\text { Filtration with } \\
\text { filter membrane } \\
(0.45 \mu \mathrm{m}) \\
\text { Dialysis } \\
\text { (1000 Da, } 3 \text { days })\end{array}$ & 6.4 & $\begin{array}{l}\text { PEI-CD: } \\
21.49\end{array}$ & {$[129$} \\
\hline $\begin{array}{l}\text { Gene therapy } \\
\text { Bioimaging }\end{array}$ & $\begin{array}{l}\text { Kaposi's sarcoma- } \\
\text { associated herpes } \\
\text { virus (KSHV) cells } \\
\text { (in vivo and } \\
\text { in vitro) }\end{array}$ & $\begin{array}{l}\text { locked nucleic acid } \\
\text { (LNA) }\end{array}$ & Viral miRNAs & Microwave-assisted & $\begin{array}{l}\text { Citric acid } \\
\text { PEI }\end{array}$ & $1150 \mathrm{~W}, 3 \mathrm{~min}$ & $\begin{array}{l}\text { locked nucleic acid } \\
\text { (LNA) functionalized }\end{array}$ & $\begin{array}{c}\text { Centrifugation } \\
(13,000 \times \text { g rpm, } \\
10 \mathrm{~min}) \\
\text { Dialysis } \\
(14,000 \mathrm{Da} \\
2 \text { days })\end{array}$ & 3.0 & $\mathrm{n} / \mathrm{a}$ & {$[130$} \\
\hline Bioimaging & HeLa cells & $\begin{array}{l}\text { Human serum } \\
\text { albumin }\end{array}$ & gp60 & Pyrolysis & $\begin{array}{l}\text { Tartaric acid } \\
\text { L-tyrosine }\end{array}$ & $220^{\circ} \mathrm{C}, 30 \mathrm{~min}$ & HSA modified & $\mathrm{n} / \mathrm{a}$ & 5.50 & $\mathrm{n} / \mathrm{a}$ & [85] \\
\hline $\begin{array}{l}\text { Drug delivery } \\
\text { Bioimaging }\end{array}$ & $\begin{array}{l}\text { HeLa and HEK } 293 \\
\text { T cells }\end{array}$ & Doxorubicin & $\begin{array}{c}\text { Folate } \\
\text { receptors }\end{array}$ & Hydrothermal & $\begin{array}{l}\text { Citric acid } \\
\text { BPEI } \\
\text { folic acid }\end{array}$ & $200^{\circ} \mathrm{C}, 4 \mathrm{~h}$ & $\begin{array}{c}\text { Polymer passivation } \\
\beta \text {-cyclodextrin } \\
\text { modified }\end{array}$ & $\begin{array}{c}\text { Centrifugation } \\
(10,000 \times \text { rpm, } \\
15 \mathrm{~min}) \\
\text { Dialysis } \\
(100-500 \mathrm{Da} \\
48 \mathrm{~h})\end{array}$ & 2.8 & 64.5 & [87] \\
\hline
\end{tabular}


Table 3. Cont.

\begin{tabular}{|c|c|c|c|c|c|c|c|c|c|c|c|}
\hline Application & Target & Ligands & Receptor & $\begin{array}{l}\text { CQDs Synthesis } \\
\text { Method }\end{array}$ & Precursors & $\begin{array}{c}\text { Reaction } \\
\text { Conditions }\end{array}$ & $\begin{array}{l}\text { Modifications and } \\
\text { Functionalization }\end{array}$ & Purification & $\begin{array}{c}\text { Average } \\
\text { Size (nm) }\end{array}$ & QY (\%) & Ref. \\
\hline $\begin{array}{l}\text { Antioxidant } \\
\text { capacity } \\
\text { enhancement }\end{array}$ & $\begin{array}{l}\text { Arabidopsis } \\
\text { thaliana seedlings }\end{array}$ & Phenol & $\begin{array}{l}\text { Horseradish } \\
\text { peroxidase }\end{array}$ & Electrochemical & Ammonia & $\begin{array}{c}\text { certain } \\
\text { voltage with } \\
\text { graphite } \\
\text { electrodes; } \\
\text { electrolyte of a } \\
\text { certain } \\
\text { concentration } \\
\text { of ammonia } \\
\text { aqueous } \\
\text { solution; } \\
\text { several days }\end{array}$ & $\begin{array}{c}\text { N-doping } \\
\text { Horseradish peroxidase } \\
\text { modified } \\
\text { (immobilization) }\end{array}$ & $\begin{array}{c}\text { Centrifugation } \\
(10,000 \times \text { g rpm, } \\
15 \mathrm{~min}) \\
\text { Dialysis } \\
(3500 \mathrm{Da} \\
\text { membrane })\end{array}$ & $\mathrm{n} / \mathrm{a}$ & $\mathrm{n} / \mathrm{a}$ & [88] \\
\hline \multirow{2}{*}{$\begin{array}{l}\text { Gene therapy } \\
\text { Bioimaging }\end{array}$} & \multirow{2}{*}{ HeLa cells } & \multirow{2}{*}{ Cy5-labelled DNA } & \multirow{2}{*}{$\mathrm{n} / \mathrm{a}$} & \multirow{2}{*}{ Hydrothermal } & $\begin{array}{l}\text { Citric acid } \\
\text { Pcyclen }\end{array}$ & \multirow{2}{*}{$180^{\circ} \mathrm{C}, 5 \mathrm{~h}$} & \multirow{2}{*}{ Polymer passivation } & \multirow{2}{*}{$\begin{array}{c}\text { Centrifugation } \\
(12,000 \times g \mathrm{rpm}, \\
10 \mathrm{~min}) \\
\text { Dialysis } \\
\text { (1000 Da, } 1 \text { day })\end{array}$} & 1.8 & 3.25 & \multirow{2}{*}{89} \\
\hline & & & & & $\begin{array}{l}\text { Citric acid } \\
\text { Ptaea }\end{array}$ & & & & 5.4 & 1.73 & \\
\hline $\begin{array}{l}\text { Antioxidant } \\
\text { capacity }\end{array}$ & $\begin{array}{l}\text { human dermal } \\
\text { fibroblasts }\end{array}$ & $\mathrm{n} / \mathrm{a}$ & $\mathrm{n} / \mathrm{a}$ & Microwave-assisted & $\begin{array}{c}\text { L-lysine } \\
\text { Propylene carbonate }\end{array}$ & $\begin{array}{l}240^{\circ} \mathrm{C} \\
120 \mathrm{~min}\end{array}$ & Polymer passivation & $\begin{array}{c}\text { Dialysis } \\
(500-1000 \mathrm{Da} \\
\text { time n/a) }\end{array}$ & $2-5$ & 23.3 & [90] \\
\hline $\begin{array}{l}\text { Drug delivery } \\
\text { Bioimaging }\end{array}$ & MCF-7 cells & Methotrexate & Folate receptors & Microwave-assisted & $\begin{array}{l}\text { Gelatin } \\
\text { PEG }\end{array}$ & $600 \mathrm{~W}, 10 \mathrm{~min}$ & Polymer passivation & $\begin{array}{c}\text { Centrifugation } \\
(12,000 \times g \mathrm{rpm} \\
15 \mathrm{~min})\end{array}$ & 6 & 34 & [91] \\
\hline $\begin{array}{l}\text { Bioimaging } \\
\text { Drug delivery }\end{array}$ & Nucleolus & $\begin{array}{c}\text { Protoporphyrin IX } \\
\text { (PpIX) }\end{array}$ & $\begin{array}{l}\text { RNA (nucleolus) } \\
\text { caveolae-mediated } \\
\text { endocytosis } \\
\text { (CvME), lipid } \\
\text { raft-mediated } \\
\text { endocytosis } \\
\text { (LrME), } \\
\text { clathrin-mediated } \\
\text { endocytosis } \\
\text { (CME), and } \\
\text { macropinocytosis } \\
\text { (cellular uptake) }\end{array}$ & Hydrothermal & $\begin{array}{l}m \text {-phenylenediamine } \\
\text { L_cysteine }\end{array}$ & $160^{\circ} \mathrm{C}, 10 \mathrm{~h}$ & $\begin{array}{l}\text { dicyclohexylcarbodiimide } \\
\text { (DCC) } \\
\text { 1-hydroxybenzotriazole } \\
\text { (HOBt) }\end{array}$ & $\begin{array}{c}\text { Centrifugation } \\
(15,000 \times g \mathrm{rpm}, \\
15 \mathrm{~min}) \\
\text { Dialysis (1000 } \\
\text { Da, } 2 \text { days) }\end{array}$ & $\begin{array}{l}\text { CDs-PpIX: } \\
25.2\end{array}$ & $\sim 8.4$ & {$[133$} \\
\hline
\end{tabular}


Table 3. Cont.

\begin{tabular}{|c|c|c|c|c|c|c|c|c|c|c|c|}
\hline Application & Target & Ligands & Receptor & $\begin{array}{l}\text { CQDs Synthesis } \\
\text { Method }\end{array}$ & Precursors & $\begin{array}{c}\text { Reaction } \\
\text { Conditions }\end{array}$ & $\begin{array}{l}\text { Modifications and } \\
\text { Functionalization }\end{array}$ & Purification & $\begin{array}{c}\text { Average } \\
\text { Size (nm) }\end{array}$ & QY (\%) & Ref. \\
\hline $\begin{array}{l}\text { Bioimaging } \\
\text { in vivo }\end{array}$ & $\begin{array}{c}\text { Caenorhabditis } \\
\text { elegans } \\
\text { (C. elegans) } \\
\text { BALB/c mice }\end{array}$ & $\mathrm{n} / \mathrm{a}$ & $\mathrm{n} / \mathrm{a}$ & $\begin{array}{l}\text { (i) Hydrothermal } \\
\text { treatment } \\
\text { (Blue-CQDs) } \\
\text { (ii) ortho-phosphoric } \\
\text { acid treatments } \\
\text { (Green-CQDs) }\end{array}$ & $\begin{array}{c}\text { beetroot extract (Beta } \\
\text { vulgaris) }\end{array}$ & $\begin{array}{r}150^{\circ} \mathrm{C}, 16 \mathrm{~h} \\
100^{\circ} \mathrm{C}, 2 \mathrm{~h}\end{array}$ & $\mathrm{n} / \mathrm{a}$ & $\begin{array}{l}\text { Centrifugation } \\
(1500 \times g \text { rpm, } \\
2500 \mathrm{rpm} \text { and } \\
4000 \mathrm{rpm}, \\
10 \mathrm{~min} \text { each })\end{array}$ & $\begin{array}{l}\text { (i) } 5 \\
\text { (ii) } 8\end{array}$ & $\begin{array}{l}\text { (i) } 6 \\
\text { (ii) } 5\end{array}$ & {$[134$} \\
\hline Gene delivery & $\begin{array}{c}\text { HEK } 293 \text { T, NIH } \\
\text { 3T3, COS-7, and } \\
\text { HepG2 cells } \\
\text { B16F10 and } \\
\text { A549 cells } \\
\text { Primary 3T3-L1 } \\
\text { and mESCs cells }\end{array}$ & pDNA & $\begin{array}{l}\text { Cytomembrane, } \\
\text { Karyotheca, endo- } \\
\text { some/lysosome, } \\
\text { membranes }\end{array}$ & Solvothermal & $\begin{array}{l}\text { tetrafluoroterephthalic } \\
\text { acid (fluorine) } \\
\text { terephthalic acid } \\
1.8 \mathrm{kDa} \text { branched- } \\
\text { polyethyleneimine } \\
(1.8 \mathrm{k} \mathrm{b}-\mathrm{PEI}) \\
25 \mathrm{kDa} \text { branched- } \\
\text { polyethyleneimine } \\
(25 \mathrm{k} \text { PEI) }\end{array}$ & $180^{\circ} \mathrm{C}, 6 \mathrm{~h}$ & $\begin{array}{l}\text { fluorine-doped cationic } \\
\text { CDs (FCDs): } \\
\text { tetrafluoroterephthalic } \\
\text { acid (fluorine) } \\
\text { pDNA }\end{array}$ & $\begin{array}{l}\text { Dialyzed } \\
(3.5 \mathrm{kDa} \text {, time } \\
\mathrm{n} / \mathrm{a})\end{array}$ & $\begin{array}{c}4.8 \text { (FCDs) } \\
150-200 \\
\text { (FCDs/DNA) }\end{array}$ & $\mathrm{n} / \mathrm{a}$ & [135] \\
\hline Drug delivery & $\begin{array}{l}\text { Porphyromonas } \\
\text { gingivalis } \\
\text { (P. gingivalis) }\end{array}$ & metronidazole (MET) & $\mathrm{n} / \mathrm{a}$ & Hydrothermal & chlorophyll & $240^{\circ} \mathrm{C}, 18 \mathrm{~h}$ & $\mathrm{n} / \mathrm{a}$ & $\begin{array}{l}\text { Centrifugation } \\
\quad(5000 \times g, \\
30 \text { min) } \\
\text { Filtration } \\
(0.22 \mathrm{~mm}) \\
\text { Ultrafiltration } \\
\text { membranes } \\
(3 \mathrm{kDa} \text { and } \\
30 \mathrm{kDa})\end{array}$ & $2-4$ & $56 \%$ & [136] \\
\hline \multirow[b]{2}{*}{ Cancer detection } & - & - & - & $\begin{array}{l}\text { Hydrothermal } \\
\text { (CDs) }\end{array}$ & sweet lemon peel & $\begin{array}{c}180^{\circ} \mathrm{C}, 3 \mathrm{~h} \\
(\mathrm{CDs})\end{array}$ & $\begin{array}{c}\text { 1-(3- } \\
\text { Dimethylaminopropyl)- } \\
\text { 3-ethyl carbodiimide } \\
\text { (EDC) }\end{array}$ & $\begin{array}{c}\text { Filtration } \\
\text { Concentration } \\
\text { rotary } \\
\text { evaporator }\end{array}$ & $1.5-6.5$ & \multirow[b]{2}{*}{$\mathrm{n} / \mathrm{a}$} & \multirow{3}{*}{ [137] } \\
\hline & $\begin{array}{l}\text { Triple negative } \\
\text { breast cancer } \\
\text { (TNBC) }\end{array}$ & $\begin{array}{c}\text { polyamidoamine } \\
\text { (PAMAM) } \\
\text { dendrimers (G1, G2 } \\
\text { and G3) }\end{array}$ & $\begin{array}{c}\text { Copper (II) } \\
\text { overexpressed in } \\
\text { TNBC } \\
\text { MDA-MB-231 cells }\end{array}$ & $\begin{array}{c}\text { Hydrothermal } \\
\text { (CD-PAMAM (CDP): } \\
\text { CDP1, CDP2, CDP3 }\end{array}$ & CDs & $\mathrm{RT}, 16 \mathrm{~h}$ & $\begin{array}{c}\text { N-hydroxysuccinimide } \\
\text { (NHS) } \\
\text { ethylenediamine (EDA) } \\
\text { PAMAM dendrimers } \\
\text { G1, G2 and G3 }\end{array}$ & $\begin{array}{c}\text { Dialysis } \\
\text { (3.5 } \mathrm{kDa}, 3 \text { days })\end{array}$ & $\mathrm{n} / \mathrm{a}$ & & \\
\hline $\begin{array}{l}\text { Gene therapy } \\
\text { Bioimaging } \\
\text { agent for } \\
\text { TNBC cells }\end{array}$ & $\begin{array}{l}\text { Triple negative } \\
\text { breast cancer } \\
\text { (TNBC)-MDA- } \\
\text { MB 231 } \\
\text { cell }\end{array}$ & eGFP-pDNA & $\begin{array}{l}\text { RGD receptor } \\
\alpha v \beta 3 \text { integrin }\end{array}$ & $\begin{array}{c}\text { Hydrothermal } \\
\text { (RGDS decorated } \\
\text { CDP3 (CDP3-RGDS)) }\end{array}$ & $\begin{array}{c}\text { CDP conjugated } \\
\text { (PAMAM) dendrimers } \\
\text { G3 (CDP3) }\end{array}$ & $\mathrm{RT}, 16 \mathrm{~h}$ & $\begin{array}{l}\text { EDC and NHS } \\
\text { RGDS peptide }\end{array}$ & $\begin{array}{c}\text { Dialysis } \\
\text { (3.5 } \mathrm{kDa}, 3 \text { days) }\end{array}$ & $7-27$ & $\mathrm{n} / \mathrm{a}$ & \\
\hline
\end{tabular}


Table 3. Cont.

\begin{tabular}{|c|c|c|c|c|c|c|c|c|c|c|c|}
\hline Application & Target & Ligands & Receptor & $\begin{array}{l}\text { CQDs Synthesis } \\
\text { Method }\end{array}$ & Precursors & $\begin{array}{c}\text { Reaction } \\
\text { Conditions }\end{array}$ & $\begin{array}{l}\text { Modifications and } \\
\text { Functionalization }\end{array}$ & Purification & $\begin{array}{c}\text { Average } \\
\text { Size (nm) }\end{array}$ & QY (\%) & Ref. \\
\hline $\begin{array}{c}\text { Skin } \\
\text { permeability }\end{array}$ & $\begin{array}{c}\text { methicillin-sensitive } \\
\text { Staphylococcus aureus } \\
\text { (ATCC 6538) } \\
\text { methicillin-resistant } \\
\text { Staphylococcus aureus } \\
\text { (ATCC 4300) } \\
\text { Escherichia coli (ATCC } \\
\text { 25922) } \\
\text { Staphlococcus } \\
\text { epidermidis (ATCC 49134) } \\
\text { Bacillus cereus (ATCC } \\
\text { 14579) }\end{array}$ & $\mathrm{n} / \mathrm{a}$ & $\mathrm{n} / \mathrm{a}$ & Hydrothermal & $\begin{array}{l}\text { polyethyleneimine } \\
\text { (PEI) } \\
\text { citric acid (CA) }\end{array}$ & $250^{\circ} \mathrm{C}, 4 \mathrm{~h}$ & $\mathrm{~N}$-doping & $\begin{array}{c}\text { Dialysis } \\
(\geq 12,000 \mathrm{Da} \\
24 \mathrm{~h})\end{array}$ & $70-10$ & $\begin{array}{c}\text { PEI:CA } \\
\text { ratio } \\
(1: 0,5)-31 \\
(1: 1)-53 \\
(1: 2)-7.6\end{array}$ & [138] \\
\hline $\begin{array}{l}\text { Induction of } \\
\text { potent humoral } \\
\text { and cellular } \\
\text { immune } \\
\text { responses }\end{array}$ & $\begin{array}{c}\text { LnCaP cells } \\
\text { Bone marrow-derived } \\
\text { dendritic cells (BMDCs) } \\
\text { Mouse leukemic } \\
\text { monocyte macrophage } \\
\text { cells (RAW264.7) } \\
\text { BALB/c mice } \\
\text { OVA-specific CD4+T and } \\
\text { CD8 +cytotoxic T } \\
\text { lymphocytes (CTLs) }\end{array}$ & $\begin{array}{c}\text { ovalbumin (OVA) } \\
\text { antigen }\end{array}$ & $\begin{array}{l}\text { antiOVA IgG1, } \\
\text { IgG2a and } \\
\text { IgG2b }\end{array}$ & Hydrothermal & $\begin{array}{c}\mathrm{N}, \mathrm{N}^{\prime} \text {-dodecyl2- } \\
\text { hydroxyl-N,N,N } \mathrm{N}^{\prime} \mathrm{N}^{\prime}- \\
\text { tetramethyl } \\
\text { diammonium } \\
\text { dichloride (BQAS) }\end{array}$ & $180^{\circ} \mathrm{C}, 12 \mathrm{~h}$ & ovalbumin (OVA) & $\begin{array}{l}\text { Centrifugation } \\
(10,000 \times g \\
\text { rpm,15 min) } \\
\text { Dialysis (500 Da, } \\
12 / 12 \mathrm{~h})\end{array}$ & 3.74 & 7.8 & [139] \\
\hline $\begin{array}{c}\text { Cancer } \\
\text { bioimaging }\end{array}$ & $\begin{array}{l}27 \text { cancer cell lines of } \\
\text { different origin, a side } \\
\text { population (SP) of cancer } \\
\text { stem-like cells isolated } \\
\text { from MDA-MB-231 } \\
\text { cells27, brain cancer stem } \\
\text { cell lines (BCSCs), } 12 \\
\text { patient-derived and } 18 \\
\text { non-cancerous cell lines } \\
\text { mice bearing HeLa } \\
\text { tumours }\end{array}$ & $\mathrm{n} / \mathrm{a}$ & $\begin{array}{l}\text { large neutral } \\
\text { amino acid } \\
\text { transporter } \\
\text { (LAT1) }\end{array}$ & \multirow[t]{3}{*}{ Hydrothermal } & \multirow{3}{*}{$\begin{array}{c}\text { LAAM TC-CQDs: } \\
1,4,5,8- \\
\text { tetraminoanthraquinone } \\
\text { (TAAQ) } \\
\text { citric acid (CA) }\end{array}$} & \multirow[t]{3}{*}{$180^{\circ} \mathrm{C}, 2 \mathrm{~h}$} & $\mathrm{n} / \mathrm{a}$ & $\begin{array}{c}\text { Silica column } \\
\text { chromatography } \\
\text { using mixtures } \\
\text { of } \\
\text { dichloromethane } \\
\text { and methanol } \\
\text { (10:1) as eluents } \\
\text { for three rounds }\end{array}$ & \multirow[t]{3}{*}{2.45} & \multirow[t]{3}{*}{$\begin{array}{l}6.8 \text { (in } \\
\text { water) }\end{array}$} & \multirow[t]{3}{*}{140} \\
\hline Drug delivery & $\begin{array}{c}\text { cancer cells and } \\
\text { non-cancerous cells }\end{array}$ & $\begin{array}{l}\text { DNA-damaging } \\
\text { chemotherapy } \\
\text { drugs: topotecan } \\
\text { hydrochloride } \\
\text { (TPTC), DOX and } \\
\text { hydroxycamp- } \\
\text { tothecin }\end{array}$ & Nuclei DNA & & & & $\begin{array}{c}\text { topotecan } \\
\text { hydrochloride (TPTC) } \\
\text { DOX } \\
\text { hydroxycamptothecin }\end{array}$ & $\begin{array}{c}\text { Dialysis } \\
\text { (MWCO n/a, } \\
\text { timen/a) }\end{array}$ & & & \\
\hline $\begin{array}{l}\text { Brain cancer } \\
\text { imaging and } \\
\text { treatment }\end{array}$ & $\begin{array}{c}\text { mice bearing U87 brain } \\
\text { tumours }\end{array}$ & $\begin{array}{c}\text { topotecan } \\
\text { hydrochloride } \\
\text { (TPTC) }\end{array}$ & $\begin{array}{c}\text { LAT1 in } \\
\text { Blood-Brain } \\
\text { Barrier (BBB) }\end{array}$ & & & & & & & & \\
\hline
\end{tabular}


Table 3. Cont.

\begin{tabular}{|c|c|c|c|c|c|c|c|c|c|c|c|}
\hline Application & Target & Ligands & Receptor & $\begin{array}{l}\text { CQDs Synthesis } \\
\text { Method }\end{array}$ & Precursors & $\begin{array}{c}\text { Reaction } \\
\text { Conditions }\end{array}$ & $\begin{array}{l}\text { Modifications and } \\
\text { Functionalization }\end{array}$ & Purification & $\begin{array}{c}\text { Average } \\
\text { Size (nm) }\end{array}$ & QY (\%) & Ref. \\
\hline \multirow{4}{*}{$\begin{array}{l}\text { Tumour-specific } \\
\text { imaging and } \\
\text { drug delivery }\end{array}$} & \multirow{4}{*}{$\begin{array}{l}\text { HeLa and } \\
\text { CCC-ESF-1 cells }\end{array}$} & $\begin{array}{c}1,4- \\
\text { diaminoanthraquinone } \\
(1,4-\mathrm{DAAQ}\end{array}$ & \multirow{4}{*}{$\begin{array}{l}\text { LAT1-mediated } \\
\text { tumour-specific }\end{array}$} & & $\begin{array}{c}\text { 1,4-CQDs: } \\
\text { 1,4- } \\
\text { diaminoanthraquinone } \\
\text { (1,4-DAAQ) } \\
\text { citric acid (CA) }\end{array}$ & & \multirow{3}{*}{$\mathrm{n} / \mathrm{a}$} & \multirow{3}{*}{$\begin{array}{c}\text { Silica column } \\
\text { chromatography } \\
\text { using mixtures } \\
\text { of } \\
\text { dichloromethane } \\
\text { and methanol } \\
\text { (20:1) as eluents }\end{array}$} & $\mathrm{n} / \mathrm{a}$ & $\mathrm{n} / \mathrm{a}$ & \\
\hline & & $\begin{array}{c}1,5- \\
\text { diaminoanthraquinone } \\
(1,5-\mathrm{DAAQ})\end{array}$ & & & $\begin{array}{c}\text { 1,5-CQDs: } \\
1,5- \\
\text { diaminoanthraquinone } \\
\text { (1,5-DAAQ) } \\
\text { citric acid (CA) }\end{array}$ & & & & $\mathrm{n} / \mathrm{a}$ & $\mathrm{n} / \mathrm{a}$ & \\
\hline & & $\begin{array}{c}2,6- \\
\text { diaminoanthraquinone } \\
(2,6-\mathrm{DAAQ})\end{array}$ & & & $\begin{array}{c}\text { 2,6-CQDs: } \\
\text { 2,6- } \\
\text { diaminoanthraquinone } \\
\text { (2,6-DAAQ) } \\
\text { citric acid (CA) }\end{array}$ & & & & $\mathrm{n} / \mathrm{a}$ & $\mathrm{n} / \mathrm{a}$ & \\
\hline & & $\mathrm{n} / \mathrm{a}$ & & Solvothermal & $\begin{array}{l}\text { Phe-CQDs: } \\
\text { phenylalanine (Phe) }\end{array}$ & $\begin{array}{l}180^{\circ} \mathrm{C} \text { in } \\
\text { oven, } 8 \mathrm{~h}\end{array}$ & $\mathrm{n} / \mathrm{a}$ & $\begin{array}{c}\text { Silica column } \\
\text { chromatography } \\
\text { using mixtures } \\
\text { of } \\
\text { dichloromethane } \\
\text { and methanol } \\
\text { (50:1) as eluents }\end{array}$ & $\mathrm{n} / \mathrm{a}$ & $\mathrm{n} / \mathrm{a}$ & \\
\hline Bioimaging & $\begin{array}{c}\text { Mung beans } \\
\text { (Vigna radiata) } \\
\text { Human MG-63 } \\
\text { osteosarcoma cell } \\
\text { line } \\
\text { Laboratory-bred } \\
\text { strain golden } \\
\text { hamsters }\end{array}$ & $\mathrm{n} / \mathrm{a}$ & Malachite green & Hydrothermal & Sandalwood powder & $200^{\circ} \mathrm{C}, 8 \mathrm{~h}$ & $\mathrm{n} / \mathrm{a}$ & $\begin{array}{c}\text { Centrifugation } \\
(15,000 \times g \mathrm{rpm}, \\
20 \mathrm{~min}) \\
\text { Filtration } \\
(0.22 \mu \mathrm{m})\end{array}$ & 3.5 & 12 & [142] \\
\hline Bioimaging & Hepg2 cells & $\mathrm{n} / \mathrm{a}$ & $\mathrm{n} / \mathrm{a}$ & Hydrothermal & $\begin{array}{c}\text { Citric acid } \\
\text { borax } \\
p \text {-phenylenediamine }\end{array}$ & $180^{\circ} \mathrm{C}, 5 \mathrm{~h}$ & N, B-doping & $\begin{array}{c}\text { Filtration } \\
(0.22 \mu \mathrm{m}) \\
\text { Dialysis }(500 \mathrm{Da} \\
24 \mathrm{~h})\end{array}$ & 3.53 & $\mathrm{n} / \mathrm{a}$ & [143] \\
\hline
\end{tabular}


Table 4. Summarized examples of carbon quantum dots used fo0r chemical sensing.

\begin{tabular}{|c|c|c|c|c|c|c|c|c|c|c|c|}
\hline Analyte(s) & Sensing Mechanism & $\begin{array}{l}\text { CQDs } \\
\text { Synthesis } \\
\text { Method }\end{array}$ & Precursors & $\begin{array}{l}\text { Reaction } \\
\text { Conditions }\end{array}$ & $\begin{array}{l}\text { Modifications and } \\
\text { Functionalization }\end{array}$ & Purification & $\begin{array}{c}\text { Average } \\
\text { Size (nm) }\end{array}$ & QY (\%) & Linear Range & $\begin{array}{l}\text { Limit of } \\
\text { Detection }\end{array}$ & Ref. \\
\hline Folic acid & dynamic quenching & Hydrothermal & $\begin{array}{c}\text { Aconitic acid (AA) } \\
\text { 1,2-ethylenediamine (EDA) }\end{array}$ & $150^{\circ} \mathrm{C}, 5 \mathrm{~h}$ & N-doping & $\mathrm{n} / \mathrm{a}$ & 1.6 & 56.5 & $1-100 \mu \mathrm{m}$ & $40 \mathrm{~nm}$ & [31] \\
\hline $\mathrm{H}_{2} \mathrm{O}_{2}$ & static quenching & Hydrothermal & $\begin{array}{l}\text { succinic acid } \\
\text { glycerol }\end{array}$ & $250^{\circ} \mathrm{C}, 6 \mathrm{~h}$ & $\mathrm{n} / \mathrm{a}$ & $\begin{array}{c}\text { Dialysis }(1000 \text { Da, } 3 \text { days }) \\
\text { Centrifugation }(10,000 \times g \\
\text { rpm, } 20 \mathrm{~min})\end{array}$ & 4.6 & 11 & $100-500 \mathrm{~nm}$ & $\begin{array}{l}21.9 \mu \mathrm{m} \\
0.7 \mu \mathrm{m}\end{array}$ & {$[33$} \\
\hline Picric acid & FRET & Hydrothermal & $\begin{array}{l}\text { L-Lysine } \\
\text { thiourea }\end{array}$ & $220^{\circ} \mathrm{C}, 5 \mathrm{~h}$ & $\mathrm{~N}, \mathrm{~S}$-doping & $\begin{array}{l}\text { Centrifugation }(10,000 \times g \\
\text { rpm, } 10 \mathrm{~min})\end{array}$ & 6.86 & 53.19 & $1-10 \mu \mathrm{m}$ & $0.24 \mu \mathrm{m}$ & [34] \\
\hline $\mathrm{Cr}(\mathrm{VI})$ & IFE & $\begin{array}{l}\text { Continuous } \\
\text { hydrothermal } \\
\text { flow }\end{array}$ & $\begin{array}{l}\text { citric acid } \\
\text { ammonia }\end{array}$ & $450^{\circ} \mathrm{C}$ & N-doping & $\begin{array}{c}\text { Filtration }(0.22 \mu \mathrm{m} \text { alumina } \\
\text { membrane }) \\
\text { Dialysis }(30 \mathrm{kDa}, 1 \mathrm{kDa} \\
\text { time } \mathrm{n} / \mathrm{a})\end{array}$ & $3.3 \pm 0.7$ & $14.91 \pm 0.24$ & 5-250 ppm & $0.365 \mathrm{ppm}$ & [22] \\
\hline Tetracycline & static quenching & $\begin{array}{l}\text { Microwave- } \\
\text { assisted }\end{array}$ & $\begin{array}{l}\text { glycerol } \\
\text { urea }\end{array}$ & $700 \mathrm{~W}, 4 \mathrm{~min}$ & N-doping & $\begin{array}{c}\text { Centrifugation }(3000 \times g \\
\text { rpm, } 4 \mathrm{~min}) \\
\text { Dialysis }(12,000 \mathrm{Da}, 3 \text { days })\end{array}$ & 13.2 & 9.8 & $0.50-25 \mu \mathrm{m}$ & $165 \mathrm{~nm}$ & [36] \\
\hline Levofloxacin & ET & $\begin{array}{l}\text { Microwave- } \\
\text { assisted }\end{array}$ & $\begin{array}{c}\text { L-cysteine } \\
\text { ammonium citrate }\end{array}$ & $750 \mathrm{~W}, 2.5 \mathrm{~min}$ & $\mathrm{~N}, \mathrm{~S}$-doping & $\mathrm{n} / \mathrm{a}$ & 2 & 64 & $0.01-70 \mathrm{mg} \mathrm{L}^{-1}$ & $5.1 \mu \mathrm{g} \mathrm{L}^{-1}$ & [24] \\
\hline $\begin{array}{c}\text { Alkaline } \\
\text { phosphatase }\end{array}$ & $\begin{array}{c}\text { fluorescence } \\
\text { quenching (ON-OFF) }\end{array}$ & Electrochemical & $\begin{array}{c}\text { Pyrocatechol } \\
\text { ethanediamine }\end{array}$ & $10 \mathrm{~V} \mathrm{DC}, 30 \mathrm{~min}$ & N-doping & Dialysis (3500 Da, 1 day) & 3.15 & $30.6 \pm 0.12$ & $5-500 \mu \mathrm{m}$ & $0.5 \mu \mathrm{m}$ & [42] \\
\hline $\begin{array}{l}\text { Alkaline } \\
\text { phosphatase }\end{array}$ & $\begin{array}{l}\text { ratiometric } \\
\text { fluorescence }\end{array}$ & Electrochemical & [BMIM][BF4] & $15 \mathrm{~V} \mathrm{DC}, 4 \mathrm{~h}$ & $\begin{array}{c}\text { Ionic liquid- } \\
\text { functionalization }\end{array}$ & $\begin{array}{l}\text { Centrifugation }(10,000 \times g \\
\text { rpm, } 20 \mathrm{~min}) \\
\text { Dialysis }(1000 \mathrm{Da}, 2 \text { days })\end{array}$ & 2.75 & 23.4 & $\begin{array}{l}0.04-3.2 \mathrm{U} \mathrm{L}^{-1} \\
\text { (12 to } 960 \mathrm{pm} \text { ) }\end{array}$ & $\begin{array}{c}0.012 \mathrm{U} \mathrm{L}^{-1} \\
(3.6 \mathrm{pm})\end{array}$ & [43] \\
\hline $\mathrm{Fe}$ (II) & $\begin{array}{l}\text { fluorescence } \\
\text { quenching and } \\
\text { ratiometric } \\
\text { fluorescence }\end{array}$ & Ultrasonic & $\begin{array}{l}\text { dopamine hydrochloride } \\
\text { dimethylformamide }\end{array}$ & $\begin{array}{c}\text { pulsed mode } \\
(600 \mathrm{~W}, 20 \mathrm{kHz}) \\
\text { with a frequency } \\
\text { of } 1 \mathrm{~s}, 8 \mathrm{~h}\end{array}$ & N-doping & $\begin{array}{c}\text { Centrifugation (n/a rpm, } \\
\text { time n/a) } \\
\text { Dialysis (500 Da, time n/a) }\end{array}$ & $2.8-4.1$ & 3.6 & $0-50 \mu \mathrm{m}$ & $38 \mathrm{~nm}$ & [46] \\
\hline $\mathrm{Fe}$ (III) & $\begin{array}{l}\text { fluorescence } \\
\text { quenching }\end{array}$ & Pyrolysis & Aloe-Vera extract & $190^{\circ} \mathrm{C}, 20 \mathrm{~min}$ & $\mathrm{n} / \mathrm{a}$ & Dialysis (300 Da, time n/a) & $6-8$ & 12.3 & $70 \mathrm{ppb}-10 \mathrm{ppm}$ & $33 \mathrm{ppb}$ & [51] \\
\hline Dopamine & ET & Hydrothermal & polyacrylamide & $180^{\circ} \mathrm{C}, 5 \mathrm{~h}$ & N-doping & $\begin{array}{l}\text { Centrifugation }(13,000 \times g \\
\text { rpm, } 20 \mathrm{~min}) \\
\text { Filtration }(0.22 \mu \mathrm{m})\end{array}$ & 3 & 23.1 & $0.1-200 \mu \mathrm{m}$ & $0.05 \mu \mathrm{m}$ & [56] \\
\hline $\mathrm{Cr}(\mathrm{VI})$ & \multirow{3}{*}{ IFE } & \multirow{3}{*}{ Hydrothermal } & \multirow{3}{*}{$\begin{array}{c}p \text {-phenylenediamine } \\
\text { ammonia }\end{array}$} & \multirow{3}{*}{$200^{\circ} \mathrm{C}, 8 \mathrm{~h}$} & \multirow{3}{*}{$\mathrm{N}$-doping } & \multirow{3}{*}{$\begin{array}{c}\text { Dialysis ( } 500-1000 \mathrm{Da}, \\
3 \text { days) }\end{array}$} & \multirow{3}{*}{3.2} & \multirow{3}{*}{13.2} & $0.0375-3 \mu \mathrm{m}$ & $22.5 \mathrm{~nm}$ & \multirow{3}{*}{ [57] } \\
\hline $\begin{array}{c}2,4,6- \\
\text { Trinitrophenol } \\
\text { (TNP) }\end{array}$ & & & & & & & & & $19-27 \mu \mathrm{m}$ & $3.69 \mu \mathrm{m}$ & \\
\hline ascorbic acid & & & & & & & & & 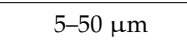 & $3.2 \mu \mathrm{m}$ & \\
\hline
\end{tabular}


Table 4. Cont.

\begin{tabular}{|c|c|c|c|c|c|c|c|c|c|c|c|}
\hline Analyte(s) & Sensing Mechanism & $\begin{array}{l}\text { CQDs } \\
\text { Synthesis } \\
\text { Method }\end{array}$ & Precursors & $\begin{array}{c}\text { Reaction } \\
\text { Conditions }\end{array}$ & $\begin{array}{l}\text { Modifications and } \\
\text { Functionalization }\end{array}$ & Purification & $\begin{array}{c}\text { Average } \\
\text { Size (nm) }\end{array}$ & QY (\%) & Linear Range & $\begin{array}{l}\text { Limit of } \\
\text { Detection }\end{array}$ & Ref. \\
\hline $\mathrm{Fe}(\mathrm{III})$ & dynamic quenching & Hydrothermal & $\begin{array}{c}\text { o-phenylenediamine (OPD) } \\
2,5 \text { pyridinedicarboxylic } \\
\text { acid (2,5 PDC) }\end{array}$ & $180^{\circ} \mathrm{C}, 5 \mathrm{~h}$ & N-doping & $\begin{array}{c}\text { Centrifugation (n/a rpm, } \\
\text { time } n / \mathrm{a}) \\
\text { Filtration }(0.22 \mu \mathrm{m}) \\
\text { Dialysis }(3500 \mathrm{Da}, 1 \text { day })\end{array}$ & 4.7 & 47 & $3-60 \mu \mathrm{m}$ & $0.31 \mu \mathrm{m}$ & {$[58$} \\
\hline Amoxicillin & $\begin{array}{l}\text { fluorescence } \\
\text { enhancement }\end{array}$ & Hydrothermal & $\begin{array}{l}\text { citric acid } \\
\text { boric acid }\end{array}$ & $210^{\circ} \mathrm{C}, 24 \mathrm{~h}$ & B-doping & Filtration $(0.22 \mu \mathrm{m})$ & 2.3 & 30.85 & $1.43-429.12 \mu \mathrm{m}$ & $0.825 \mu \mathrm{m}$ & {$[60]$} \\
\hline $\begin{array}{c}\text { Potassium } \\
\text { sorbate }\end{array}$ & FRET & Hydrothermal & phenylboronic acid & $200^{\circ} \mathrm{C}, 10 \mathrm{~h}$ & B-doping & $\begin{array}{c}\text { Centrifugation }(7060 \times g \\
15 \mathrm{~min}) \\
\text { Filtration }(0.22 \mu \mathrm{m}) \\
\text { Dialysis }(100 \mathrm{Da}, 48 \mathrm{~h})\end{array}$ & 3.3 & 12 & $0.20-24 \mu \mathrm{m}$ & $6.1 \mathrm{~nm}$ & {$[61$} \\
\hline $\mathrm{Cd}(\mathrm{II})$ & $\begin{array}{l}\text { fluorescence } \\
\text { enhancement }\end{array}$ & Hydrothermal & $\begin{array}{l}\text { o-phosphorylethanolamine } \\
\text { citric acid }\end{array}$ & $180^{\circ} \mathrm{C}, 12 \mathrm{~h}$ & $\mathrm{~N}, \mathrm{P}$-doping & $\begin{array}{c}\text { Dialysis }(1000 \mathrm{Da}, \\
\text { overnight) } \\
\text { Filtration }(0.22 \mu \mathrm{m})\end{array}$ & 1.6 & 8.17 & $0.5-12.5 \mu \mathrm{m}$ & $0.16 \mu \mathrm{m}$ & [63] \\
\hline $\mathrm{Cu}(\mathrm{II})$ & IFE & Hydrothermal & $\begin{array}{c}\text { Glucose } \\
\text { concentrated } \mathrm{H}_{3} \mathrm{PO}_{4} \\
\text { polyethylene glycol diamine }\end{array}$ & $90-100^{\circ} \mathrm{C}, 9 \mathrm{~h}$ & N,P-doping & $\begin{array}{l}\text { Centrifugation }(14,000 \times g \\
\text { rpm, } 30 \mathrm{~min}) \\
\text { Dialysis }(1000 \mathrm{Da}, 1 \text { day })\end{array}$ & 3.5 & 25 & $\begin{array}{c}4 \times 10^{-9}- \\
4 \times 10^{-7} \mathrm{M}\end{array}$ & $1.5 \mathrm{~nm}$ & [64] \\
\hline Curcumin & IFE & $\begin{array}{l}\text { Self-exothermic } \\
\text { reaction }\end{array}$ & $\begin{array}{c}\text { Glucose } \\
\text { 1,2-ethylenediamine } \\
\text { concentrated phosphoric } \\
\text { acid }\end{array}$ & $\begin{array}{c}\text { acid-base } \\
\text { neutralization } \\
\text { spontaneous } \\
\text { heat, } 6 \mathrm{~min} \\
\end{array}$ & $\mathrm{~N}, \mathrm{P}$-doping & Dialysis (1000 $\mathrm{Da}, 3$ days) & $3.5 \pm 0.2$ & 9.59 & $0.5-20 \mu \mathrm{m}$ & $58 \mathrm{~nm}$ & [65] \\
\hline $\mathrm{Cr}_{2} \mathrm{O}_{7^{2-}}$ & $\begin{array}{l}\text { fluorescence } \\
\text { quenching }\end{array}$ & $\begin{array}{l}\text { Microwave- } \\
\text { assisted }\end{array}$ & $\begin{array}{l}\text { 1,6-hexanediamine } \\
\text { dihydrochloride } \\
\text { dimethyl sulfoxide }\end{array}$ & $180^{\circ} \mathrm{C}, 35 \mathrm{~min}$ & $\mathrm{~N}, \mathrm{~S}$-doping & $\begin{array}{l}\text { Filtration }(0.22 \mu \mathrm{m}) \\
\text { Dialysis }(500 \mathrm{Da}, 36 \mathrm{~h})\end{array}$ & 4.35 & 24 & $\begin{array}{l}\text { Linearity not } \\
\text { satisfied }\end{array}$ & $0.23 \mu \mathrm{m}$ & {$[69$} \\
\hline Permanganate & \multirow{2}{*}{ static quenching } & \multirow{2}{*}{ Hydrothermal } & \multirow{2}{*}{$\begin{array}{c}\text { p-amino salicylic acid } \\
\text { boric acid } \\
\text { ethylene glycol } \\
\text { dimethacrylate }\end{array}$} & \multirow{2}{*}{$180^{\circ} \mathrm{C}, 5 \mathrm{~h}$} & \multirow[t]{2}{*}{ N,B-doping } & \multirow{2}{*}{$\begin{array}{c}\text { Centrifugation }(12,000 \times g \\
\text { rpm, } 15 \mathrm{~min}) \\
\text { Filtration }(0.22 \mu \mathrm{m}) \\
\text { Dialysis }(1000 \mathrm{Da}, 1 \text { day })\end{array}$} & \multirow{2}{*}{5} & \multirow{2}{*}{19.6} & $0.05-60 \mu \mathrm{m}$ & $13 \mathrm{~nm}$ & [71] \\
\hline Captopril & & & & & & & & & $0.1-60 \mu \mathrm{m}$ & $0.03 \mu \mathrm{m}$ & \\
\hline Glucose & $\begin{array}{l}\text { aggregation-induced } \\
\text { emission (AIE) }\end{array}$ & Hydrothermal & $\begin{array}{c}\text { 4-carboxyphenylboronic } \\
\text { acid } \\
\text { o-phenylenediamine } \\
\text { rhodamine B }\end{array}$ & $150^{\circ} \mathrm{C}, 5 \mathrm{~h}$ & N,B-doping & $\begin{array}{l}\text { Centrifugation (rpm n/a, } \\
\text { time } \mathrm{n} / \mathrm{a} \text { ) }\end{array}$ & 30 & 46 & $32 \mu \mathrm{m}-2 \mathrm{~mm}$ & $8 \mu \mathrm{m}$ & [73] \\
\hline Tetracycline & IFE & Ultrasonic & $\begin{array}{l}\text { thiamine } \\
\text { pyrophosphate }\end{array}$ & $\begin{array}{l}\text { alkaline solution, } \\
\text { room } \\
\text { temperature, } \\
240 \mathrm{~min}\end{array}$ & $\mathrm{~N}, \mathrm{~S}, \mathrm{P}$-doping & Dialysis (2000 Da, 48 h) & 3.19 & 20.5 & $0.1-20 \mu \mathrm{m}$ & $0.0444 \mu \mathrm{m}$ & [74] \\
\hline $\mathrm{Cr}(\mathrm{VI})$ & IFE & Hydrothermal & $\begin{array}{l}\text { p-aminobenzenesulfonic } \\
\text { acid } \\
\text { tetrakis(hydroxymethyl) } \\
\text { phosphonium chloride }\end{array}$ & $180^{\circ} \mathrm{C}, 10 \mathrm{~h}$ & $\mathrm{~N}, \mathrm{~S}, \mathrm{P}$-doping & $\begin{array}{c}\text { Filtration }(0.22 \mu \mathrm{m}) \\
\text { Dialysis }(500 \mathrm{Da}, 72 \mathrm{~h})\end{array}$ & 2.18 & 36.8 & $1-500 \mu \mathrm{m}$ & $0.23 \mu \mathrm{m}$ & [75] \\
\hline
\end{tabular}


Table 4. Cont.

\begin{tabular}{|c|c|c|c|c|c|c|c|c|c|c|c|}
\hline Analyte(s) & Sensing Mechanism & $\begin{array}{l}\text { CQDs } \\
\text { Synthesis } \\
\text { Method }\end{array}$ & Precursors & $\begin{array}{c}\text { Reaction } \\
\text { Conditions }\end{array}$ & $\begin{array}{l}\text { Modifications and } \\
\text { Functionalization }\end{array}$ & Purification & $\begin{array}{c}\text { Average } \\
\text { Size (nm) }\end{array}$ & QY (\%) & Linear Range & $\begin{array}{c}\text { Limit of } \\
\text { Detection }\end{array}$ & Ref. \\
\hline miRNA-9 & $\begin{array}{l}\text { fluorescence } \\
\text { enhancement }\end{array}$ & Hydrothermal & $\begin{array}{c}\text { Thiourea } \\
o \text {-phenylenediamine }\end{array}$ & $200^{\circ} \mathrm{C}, 8 \mathrm{~h}$ & N-doping & $\begin{array}{c}\text { Filtration }(0.22 \mu \mathrm{m}) \\
\text { Dialysis (MWCO n/s, time } \\
\mathrm{n} / \mathrm{a})\end{array}$ & $3.6 \pm 0.5$ & $\mathrm{n} / \mathrm{a}$ & $4.00-250 \mathrm{fm}$ & $\begin{array}{c}0.57 \pm 0.12 \\
\mathrm{fm}\end{array}$ & {$[144$} \\
\hline Thiourea & $\begin{array}{l}\text { static quenching } \\
\text { (ON-OFF) }\end{array}$ & Hydrothermal & $\begin{array}{l}\text { ammonium citrate } \\
\text { dextrin }\end{array}$ & $165^{\circ} \mathrm{C}, 5.5 \mathrm{~h}$ & N-doping & Filtration $(0.22 \mu \mathrm{m})$ & 1 & 17 & $0.90-10.0 \mu \mathrm{m}$ & $0.15 \mu \mathrm{m}$ & {$[145$} \\
\hline Catechol & \multirow{2}{*}{$\begin{array}{l}\text { photoelectron } \\
\text { transfer }\end{array}$} & \multirow{2}{*}{ Hydrothermal } & \multirow{2}{*}{$\begin{array}{l}\text { citric acid } \\
\text { sodium tetraphenylborate }\end{array}$} & \multirow{2}{*}{$180^{\circ} \mathrm{C}, 8 \mathrm{~h}$} & \multirow{2}{*}{ B-doping } & \multirow{2}{*}{$\begin{array}{l}\text { Extraction method with } \\
\mathrm{CCl}_{4} / \mathrm{H}_{2} \mathrm{O}\end{array}$} & \multirow{2}{*}{8} & \multirow{2}{*}{42} & $1-50 \mathrm{~nm}$ & $0.25 \mathrm{~nm}$ & \multirow{2}{*}{146} \\
\hline Glutathione & & & & & & & & & $2-100 \mathrm{~nm}$ & $0.5 \mathrm{~nm}$ & \\
\hline Dopamine & \multirow{2}{*}{$\begin{array}{l}\text { fluorescence } \\
\text { quenching }\end{array}$} & \multirow{2}{*}{ Hydrothermal } & \multirow{2}{*}{$\begin{array}{l}\text { anhydrous citric acid } \\
\text { ethylenediamine }\end{array}$} & \multirow{2}{*}{$150^{\circ} \mathrm{C}, 2 \mathrm{~h}$} & \multirow{2}{*}{ N-doping } & \multirow{2}{*}{ Dialysis (3000 Da, 2 days) } & \multirow{2}{*}{$\mathrm{n} / \mathrm{a}$} & \multirow{2}{*}{$\mathrm{n} / \mathrm{a}$} & $0.05-15 \mu \mathrm{m}$ & $0.035 \mu \mathrm{m}$ & \multirow{2}{*}{148} \\
\hline$\alpha$-lipoic acid & & & & & & & & & $0.5-55 \mu \mathrm{m}$ & $0.39 \mu \mathrm{m}$ & \\
\hline $\mathrm{Ca}(\mathrm{II})$ & static quenching & Hydrothermal & $\begin{array}{l}\text { 1st) citric acid and } \\
\text { ethylenediamine } \\
\text { 2nd) } \\
\text { thylenebis(oxyethylenenitrilo) } \\
\text { tetraacetic acid (EGTA) }\end{array}$ & $\begin{array}{c}180^{\circ} \mathrm{C}, \\
8 \mathrm{~h}+150^{\circ} \mathrm{C}, 4 \mathrm{~h}\end{array}$ & $\begin{array}{c}\text { EGTA } \\
\text { functionalized }\end{array}$ & $\begin{array}{l}\text { Centrifugation }(10,000 \times g \\
\quad \mathrm{rpm} \text {, time n/a) } \\
\text { Dialysis }(500 \mathrm{Da}, 1 \text { day })\end{array}$ & 5 & $\mathrm{n} / \mathrm{a}$ & $15-300 \mu \mathrm{m}$ & $0.387 \mu \mathrm{m}$ & {$[149$} \\
\hline $\mathrm{Fe}$ (II) & $\begin{array}{l}\text { fluorescence } \\
\text { quenching }\end{array}$ & Pyrolysis & $\begin{array}{c}\text { mango (Mangifera indica) } \\
\text { leaves }\end{array}$ & $300^{\circ} \mathrm{C}, 3 \mathrm{~h}$ & $\mathrm{n} / \mathrm{a}$ & Vacuum filtration & 2 to 10 & 18.2 & $\begin{array}{c}0-1000 \mu \mathrm{L} \text { of } \\
10 \mathrm{ppm} \mathrm{Fe} \text { (II) }\end{array}$ & $0.62 \mathrm{ppm}$ & {$[150$} \\
\hline $\mathrm{S}^{2-}$ & static quenching & Pyrolysis & Vitis vinifera grape juice & $200^{\circ} \mathrm{C}, 6 \mathrm{~h}$ & $\begin{array}{c}\text { Polyamine } \\
\text { functionalized }\end{array}$ & Filtration $(0.45 \mu \mathrm{m})$ & 8 & 32.1 & $0.8-95 \mu \mathrm{m}$ & $0.24 \mu \mathrm{m}$ & {$[151$} \\
\hline $\mathrm{Cr}(\mathrm{VI})$ & \multirow[b]{2}{*}{$\begin{array}{l}\text { dynamic and static } \\
\text { quenching }\end{array}$} & \multirow[b]{2}{*}{ Hydrothermal } & \multirow[b]{2}{*}{ Potato } & \multirow[b]{2}{*}{$\begin{array}{l}150^{\circ} \mathrm{C}, 90 \mathrm{~min} \\
200^{\circ} \mathrm{C}, 2.5 \mathrm{~h}\end{array}$} & \multirow[b]{2}{*}{$\mathrm{n} / \mathrm{a}$} & \multirow{2}{*}{$\begin{array}{c}\text { Filtration } \\
\text { Paper filtration }(11 \mu \mathrm{m}) \\
\text { Centrifugation }(12,000 \times g \\
\text { rpm, } 10 \mathrm{~min}) \\
\end{array}$} & \multirow[b]{2}{*}{5.97} & & $0.5-100 \mu \mathrm{m}$ & $0.012 \mu \mathrm{m}$ & \\
\hline $\mathrm{Fe}$ (III) & & & & & & & & 6.08 & $0.5-5 \mu \mathrm{m}$ & $\begin{array}{c}0.000549 \\
\mu \mathrm{m}\end{array}$ & [152 \\
\hline $\mathrm{Pb}(\mathrm{II})$ & ET & Hydrothermal & $\begin{array}{c}\text { L-lysine } \\
\text { L-glutathione }\end{array}$ & $190^{\circ} \mathrm{C}, 24 \mathrm{~h}$ & $\begin{array}{c}\text { Thiol- } \\
\text { functionalized }\end{array}$ & $\begin{array}{c}\text { Filtration } \\
\text { Centrifugation }(8000 \times g \\
\text { rpm, } 20 \mathrm{~min})\end{array}$ & 5 & $\mathrm{n} / \mathrm{a}$ & $0-20 \mu \mathrm{m}$ & $2.2 \mu \mathrm{m}$ & [83] \\
\hline Glucose & $\begin{array}{l}\text { fluorescence } \\
\text { quenching }\end{array}$ & $\begin{array}{l}\text { Microwave- } \\
\text { assisted }\end{array}$ & $\begin{array}{l}\text { citric acid } \\
\text { tyramine }\end{array}$ & $800 \mathrm{~W}, 120 \mathrm{~s}$ & $\begin{array}{l}\text { N-doping; } \\
\text { Tyramine } \\
\text { hybridized }\end{array}$ & $\begin{array}{c}\text { Centrifugation }(9000 \times g \\
\text { rpm, } 15 \mathrm{~min}) \\
\text { Filtration }(0.45 \mu \mathrm{m})\end{array}$ & 17.5 & $11.0 \pm 0.8$ & $10^{-6}-10^{-5} \mathrm{M}$ & $\mathrm{n} / \mathrm{a}$ & [84] \\
\hline $\mathrm{Pb}$ (II) & static quenching & $\begin{array}{l}\text { Microwave- } \\
\text { assisted }\end{array}$ & $\begin{array}{c}\text { Urea } \\
\text { citric acid } \\
\text { boric acid }\end{array}$ & $700 \mathrm{~W}, 4 \mathrm{~min}$ & $\begin{array}{l}\text { N,B-doping; BSA } \\
\text { modified }\end{array}$ & $\begin{array}{l}\text { Dialysis ( } 500 \text { Da membrane, } \\
1 \text { day) }\end{array}$ & $<5$ & $\mathrm{n} / \mathrm{a}$ & $1-10 \mathrm{ppb}$ & $0.08 \mathrm{ppb}$ & [86] \\
\hline $\mathrm{Fe}$ (III) & $\begin{array}{l}\text { fluorescence static } \\
\text { quenching }\end{array}$ & Solvothermal & $\begin{array}{c}\text { Glycerol } \\
\text { N-[3- } \\
\text { (trimethoxysilyl)propyl] } \\
\text { ethylenediamine (DAMO) }\end{array}$ & $\begin{array}{c}\text { degassing } \\
\text { process with } \\
\text { nitrogen, } 2 \text { min } \\
260^{\circ} \mathrm{C}, 12 \mathrm{~h}\end{array}$ & $\begin{array}{l}\text { Silicon and } \\
\text { Nitrogen } \\
\text { co-doping }\end{array}$ & $\begin{array}{l}\text { Centrifugation }(8000 \times g \\
\text { rpm, } 10 \mathrm{~min}) \\
\text { Dialysis }(\sim 1 \mathrm{kDa}, 2 \text { days })\end{array}$ & $\sim 6.1$ & 45 & $0.1-100 \mu \mathrm{m}$ & $16 \mathrm{~nm}$ & {$[132$} \\
\hline
\end{tabular}


Table 4. Cont

\begin{tabular}{|c|c|c|c|c|c|c|c|c|c|c|c|}
\hline Analyte(s) & Sensing Mechanism & $\begin{array}{l}\text { CQDs } \\
\text { Synthesis } \\
\text { Method }\end{array}$ & Precursors & $\begin{array}{c}\text { Reaction } \\
\text { Conditions }\end{array}$ & $\begin{array}{l}\text { Modifications and } \\
\text { Functionalization }\end{array}$ & Purification & $\begin{array}{c}\text { Average } \\
\text { Size }(\mathrm{nm})\end{array}$ & QY (\%) & Linear Range & $\begin{array}{c}\text { Limit of } \\
\text { Detection }\end{array}$ & Ref. \\
\hline $\mathrm{Fe}^{3+}$ & $\begin{array}{l}\text { Fluorescent } \\
\text { quenching }\end{array}$ & Hydrothermal & $\begin{array}{c}\text { Thiamine hydrochloride } \\
\text { (Vitamin B1) } \\
\text { ethylenediamine }\end{array}$ & $200^{\circ} \mathrm{C}, 12 \mathrm{~h}$ & S-doping & $\begin{array}{l}\text { Centrifugation (rpm n/a, } \\
\text { time } \mathrm{n} / \mathrm{a}) \\
\text { Dialysis ( } 3500 \mathrm{Da}, 3 \text { days) }\end{array}$ & 3.2 & 4.4 & $0.1-1.0 \mathrm{~mm}$ & $177 \mathrm{~nm}$ & {$[153$} \\
\hline \multirow[b]{2}{*}{ tetracycline } & \multirow[b]{2}{*}{$\begin{array}{l}\text { Fluorescent static } \\
\text { quenching }\end{array}$} & \multirow[b]{2}{*}{$\begin{array}{l}\text { Microwave- } \\
\text { assisted }\end{array}$} & \multirow[b]{2}{*}{$\begin{array}{c}\text { Xylan } \\
\mathrm{NH}_{4} \mathrm{OH}\end{array}$} & \multirow[b]{2}{*}{$\begin{array}{l}200{ }^{\circ} \mathrm{C}, 200 \mathrm{~W} \\
10 \mathrm{~min}\end{array}$} & $\mathrm{~N}$-doping & \multirow[b]{2}{*}{ Filtration $(0.22 \mu \mathrm{m})$} & \multirow[b]{2}{*}{7.89} & 4 & \multirow[b]{2}{*}{$0.05-20 \mu \mathrm{m}$} & \multirow[b]{2}{*}{$6.49 \mathrm{~nm}$} & \multirow[b]{2}{*}{154} \\
\hline & & & & & $\begin{array}{c}\text { Xylan-derived } \\
\text { N-CQDs without } \\
\text { N-doping }\end{array}$ & & & 2 & & & \\
\hline Hematin & $\begin{array}{l}\text { Fluorescent static } \\
\text { quenching (IFE) }\end{array}$ & Solvothermal & $\begin{array}{c}\text { p-aminobenzoic acid } \\
\text { (PABA) }\end{array}$ & $180^{\circ} \mathrm{C}, 12 \mathrm{~h}$ & $\mathrm{n} / \mathrm{a}$ & $\begin{array}{c}\text { Silica column } \\
\text { chromatography }\end{array}$ & 11.8 & $\mathrm{n} / \mathrm{a}$ & $0.5-10 \mu \mathrm{m}$ & $0.25 \mu \mathrm{m}$ & {$[155$} \\
\hline glutathione & $\begin{array}{c}\text { CQDs- } \mathrm{H}_{2} \mathrm{O}_{2}-\mathrm{TMB}(3, \\
3^{\prime}, 5,5^{\prime}- \\
\text { tetramethylbenzidine }) \\
\text { system }\end{array}$ & Acid refux & $\begin{array}{l}\text { wood soot } \\
\mathrm{HNO}_{3}\end{array}$ & $140^{\circ} \mathrm{C}, 12 \mathrm{~h}$ & $\mathrm{n} / \mathrm{a}$ & $\begin{array}{c}\text { Dialysis (MWCO n/a, } 2 \\
\text { days) } \\
\text { Centrifugation }(16,000 \times g \\
\text { rpm, } 15 \text { min) } \\
\text { Ultra-filtration }\end{array}$ & 2.3 & $\mathrm{n} / \mathrm{a}$ & $0.05-20 \mu \mathrm{m}$ & $0.016 \mu \mathrm{m}$ & {$[156$} \\
\hline $\begin{array}{l}\text { Pesticides: } \\
\text { propanyl } \\
\text { parathion } \\
\text { dimethoate } \\
\text { chlorpyrifos } \\
\text { pyrimicarb }\end{array}$ & FRET & Hydrothermal & riboflavin & $\begin{array}{l}160^{\circ} \mathrm{C}(1,2,5 \mathrm{~h}) \\
180^{\circ} \mathrm{C}(1,2,5 \mathrm{~h}) \\
200^{\circ} \mathrm{C}(1,2,5 \mathrm{~h})\end{array}$ & $\mathrm{n} / \mathrm{a}$ & $\begin{array}{l}\text { Dialysis }(12 \mathrm{~h} / 12 \mathrm{~h}) \\
\text { of "CD6 }\left(180^{\circ} \mathrm{C}, 5 \mathrm{~h}\right) \text { " }\end{array}$ & $\begin{array}{l}3.47 \pm 0.02 \\
\quad(\mathrm{CD} 6)\end{array}$ & $\mathrm{n} / \mathrm{a}$ & $\mathrm{n} / \mathrm{a}$ & $\mathrm{n} / \mathrm{a}$ & {$[157$} \\
\hline ascorbic acid & $\begin{array}{c}\text { M-CQDs- } \mathrm{H}_{2} \mathrm{O}_{2}-\mathrm{TMB} \\
\left(3,3^{\prime}, 5,55^{\prime}-\right. \\
\text { tetramethylbenzidine }) \\
\text { system }\end{array}$ & Hydrothermal & Mustard seeds & $180^{\circ} \mathrm{C}, 4 \mathrm{~h}$ & $\mathrm{n} / \mathrm{a}$ & $\begin{array}{l}\text { Centrifugation }(15,000 \times g \\
\text { rpm, } 20 \mathrm{~min})\end{array}$ & $4.58 \pm 0.26$ & 4.6 & $10-70 \mu \mathrm{m}$ & $3.26 \mu \mathrm{m}$ & {$[158$} \\
\hline Acetone & $\begin{array}{c}\text { enhancement in PL } \\
\text { emission }\end{array}$ & \multirow{2}{*}{ Hydrothermal } & \multirow{2}{*}{$\begin{array}{c}\text { citric acid } \\
\text { borax } \\
p \text {-phenylenediamine }\end{array}$} & \multirow{2}{*}{$180^{\circ} \mathrm{C}, 5 \mathrm{~h}$} & \multirow{2}{*}{ N, B-doping } & \multirow{2}{*}{$\begin{array}{c}\text { Filtration }(0.22 \mu \mathrm{m}) \\
\text { Dialysis }(500 \mathrm{Da}, 24 \mathrm{~h})\end{array}$} & \multirow{2}{*}{3.53} & \multirow{2}{*}{$\mathrm{n} / \mathrm{a}$} & $1-200 \mu \mathrm{m}$ & $0.54 \mu \mathrm{m}$ & \multirow{2}{*}{143} \\
\hline Dopamine & $\begin{array}{l}\text { static quenching } \\
\text { mechanism }\end{array}$ & & & & & & & & $0.1-70 \mu \mathrm{m}$ & $11 \mathrm{~nm}$ & \\
\hline $\begin{array}{l}\text { m-benzenediol } \\
\text { (resorcinol) }\end{array}$ & $\begin{array}{l}\text { Fluorescence } \\
\text { enhancing }\end{array}$ & \multirow{2}{*}{ Hydrothermal } & \multirow{2}{*}{ Cryptococcus } & \multirow{2}{*}{$160^{\circ} \mathrm{C}, 1 \mathrm{~h}$} & \multirow{2}{*}{$\mathrm{n} / \mathrm{a}$} & \multirow{2}{*}{$\begin{array}{c}\text { Centrifugation }(5000 \times g \\
\text { rpm, } 5 \mathrm{~min}) \\
\text { Filtration }(0.22 \mathrm{~mm}) \\
\text { Dialysis }(100 \mathrm{Da}, 12 \mathrm{~h})\end{array}$} & \multirow{2}{*}{$4-9$} & \multirow{2}{*}{14.13} & $\begin{array}{r}2 \times 10^{-8} \\
4 \times 10^{-4} \mathrm{~m}\end{array}$ & $8.68 \mathrm{~nm}$ & \multirow{2}{*}{ [159 } \\
\hline $\begin{array}{c}\text { p-benzenediol } \\
\text { ((hydro- } \\
\text { quinone) }\end{array}$ & $\begin{array}{l}\text { Fluorescence } \\
\text { quenching }\end{array}$ & & & & & & & & $\begin{array}{c}4 \times 10^{-9} \\
2 \times 10^{-5} \mathrm{M}\end{array}$ & $6.7 \mathrm{~nm}$ & \\
\hline
\end{tabular}


Table 4. Cont.

\begin{tabular}{|c|c|c|c|c|c|c|c|c|c|c|c|}
\hline Analyte(s) & Sensing Mechanism & $\begin{array}{l}\text { CQDs } \\
\text { Synthesis } \\
\text { Method }\end{array}$ & Precursors & $\begin{array}{c}\text { Reaction } \\
\text { Conditions }\end{array}$ & $\begin{array}{l}\text { Modifications and } \\
\text { Functionalization }\end{array}$ & Purification & $\begin{array}{l}\text { Average } \\
\text { Size (nm) }\end{array}$ & QY (\%) & Linear Range & $\begin{array}{c}\text { Limit of } \\
\text { Detection }\end{array}$ & Ref. \\
\hline $\mathrm{Cu}$ (II) & $\begin{array}{l}\text { Fluorescence } \\
\text { quenching }\end{array}$ & Dry-Pyrolysis & $\begin{array}{l}\text { Finger millet ragi (Eleusine } \\
\text { coracana) }\end{array}$ & $\begin{array}{c}300{ }^{\circ} \mathrm{C} \text { (step of } \\
\left.5^{\circ} \mathrm{C} / \mathrm{min}\right), 3 \mathrm{~h} \text { at } \\
300{ }^{\circ} \mathrm{C}\end{array}$ & $\mathrm{n} / \mathrm{a}$ & Filtration $(0.22 \mu \mathrm{m})$ & 6 & $\mathrm{n} / \mathrm{a}$ & $0-100 \mu \mathrm{m}$ & $10 \mathrm{~nm}$ & {$[160]$} \\
\hline Ellagic acid & $\begin{array}{l}\text { Fluorescent static } \\
\text { quenching (inner } \\
\text { filter) }\end{array}$ & Hydrothermal & $\begin{array}{c}\text { citric acid } \\
\text { diethylenetriamine }\end{array}$ & $180^{\circ} \mathrm{C}, 10 \mathrm{~h}$ & N-doping & $\begin{array}{c}\text { Dialysis tube (500 Da, time } \\
\text { n/a) }\end{array}$ & 3.16 & 84.79 & $0.01-50 \mu \mathrm{m}$ & $0.01 \mu \mathrm{m}$ & {$[161]$} \\
\hline Dimethoate & $\begin{array}{l}\text { fluorescence static } \\
\text { quenching }\end{array}$ & Dry-Pyrolysis & $\begin{array}{l}\text { pork rib bones from food } \\
\text { waste }\end{array}$ & $\begin{array}{l}\text { 1st) } 700^{\circ} \mathrm{C}, 5 \mathrm{~h} \\
2 \mathrm{nd}) \\
\text { Centrifugation } \\
\text { (6000 } \times \text { g rpm, } \\
6 \mathrm{~min}) \\
\text { 3rd) } 200^{\circ} \mathrm{C}, 10 \mathrm{~h}\end{array}$ & dithizone & Filtration $(0.22 \mu \mathrm{m})$ & $4.2 \pm 1.2$ & $\mathrm{n} / \mathrm{a}$ & $\begin{array}{c}0.15 \\
\mu \mathrm{m}-5.0 \mu \mathrm{m}\end{array}$ & $0.064 \mu \mathrm{m}$ & {$[162]$} \\
\hline $\begin{array}{l}\text { curcumin in } \\
\text { dietary foods }\end{array}$ & $\begin{array}{l}\text { IFE and dynamic } \\
\text { interaction }\end{array}$ & Solvothermal & $\begin{array}{l}m \text {-phenylenediamine } \\
\text { citric acid }\end{array}$ & $180^{\circ} \mathrm{C}, 12 \mathrm{~h}$ & $\mathrm{~N}$-doping & $\begin{array}{c}\text { Dialysis (500-1000 Da, } \\
24 / 24 / 24 \mathrm{~h})\end{array}$ & 4.5 & 61.7 & $0.01-25.0 \mu \mathrm{m}$ & $28.7 \mathrm{~nm}$ & {$[163$} \\
\hline \multirow{4}{*}{ Diazinon } & \multirow{4}{*}{$\begin{array}{l}\text { Fluorescent static } \\
\text { quenching }\end{array}$} & \multirow{3}{*}{$\begin{array}{l}\text { Hydrothermal } \\
\text { (Aqueous } \\
\text { extracts) }\end{array}$} & Blue rose petals & \multirow{4}{*}{$200^{\circ} \mathrm{C}, 2 \mathrm{~h}$} & \multirow{4}{*}{$\mathrm{n} / \mathrm{a}$} & \multirow{4}{*}{ Filtration } & 37 & 46 & \multirow{4}{*}{$0.02-10 \mu \mathrm{m}$} & \multirow{4}{*}{$0.01 \mu \mathrm{m}$} & \multirow{4}{*}{164} \\
\hline & & & Red rose petals & & & & 39 & 44 & & & \\
\hline & & & Yellow rose petals & & & & 33 & 48 & & & \\
\hline & & $\begin{array}{l}\text { Solvothermal } \\
\text { (Alcoholic } \\
\text { extracts) }\end{array}$ & Blue rose petals & & & & 30 & 43 & & & \\
\hline \multirow{3}{*}{$\begin{array}{l}\text { Ovalbumin } \\
\text { (OVA) }\end{array}$} & \multirow{3}{*}{ C-MIPs@FITC } & \multirow{3}{*}{ Hydrothermal } & $\begin{array}{c}\text { citric acid } \\
\text { ethylenediamine }\end{array}$ & $200^{\circ} \mathrm{C}, 5 \mathrm{~h}$. & N-doping & Dialysis (MWCO n/a, 24 h) & $\mathrm{n} / \mathrm{a}$ & \multirow{3}{*}{$\mathrm{n} / \mathrm{a}$} & \multirow{3}{*}{$0.05-2 \mu \mathrm{m}$} & \multirow{3}{*}{$15.4 \mathrm{~nm}$} & \multirow{3}{*}{165} \\
\hline & & & $\begin{array}{c}\mathrm{SiO}_{2} \mathrm{NPs} \text { (i) } \\
\mathrm{OVAA}(\mathrm{i}) \\
\text { APTES (i) } \\
\text { TEOS (ii) } \\
\mathrm{NH}_{3} \cdot \mathrm{H}_{2} \mathrm{O} \text { (ii) } \\
\text { FITC (iii) }\end{array}$ & $\begin{array}{l}\text { (i) Stirring } 1 \mathrm{~h} \\
\text { (ii) Stirring } 24 \mathrm{~h} \\
\text { (iii) Stirring } 2 \mathrm{~h}\end{array}$ & $\begin{array}{l}\text { (MIPs@FITC) } \\
\text { OVA fluorescent } \\
\text { imprinted } \\
\text { nanoparticles }\end{array}$ & $\begin{array}{c}\text { (ii) centrifugation and } \\
\text { washing } \\
\text { w/methanol/acetic acid } \\
(9: 1, v / v) \\
\text { (iii) washing w/ethanol }\end{array}$ & 90 & & & & \\
\hline & & & $\begin{array}{c}\text { CDs } \\
\text { MIPs@FITC } \\
\text { PBS }\end{array}$ & mixing & $\begin{array}{c}\text { (C-MIPs@FITC) } \\
\text { molecularly } \\
\text { imprinted } \\
\text { ratiometric } \\
\text { fluorescence } \\
\text { nanosensor }\end{array}$ & $\mathrm{n} / \mathrm{a}$ & $\mathrm{n} / \mathrm{a}$ & & & & \\
\hline
\end{tabular}




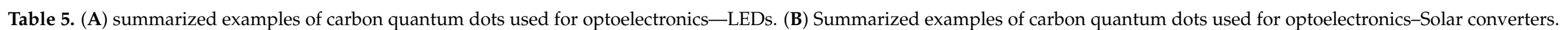

\begin{tabular}{|c|c|c|c|c|c|c|c|c|c|c|c|}
\hline \multicolumn{12}{|c|}{ (A) } \\
\hline Application & CCT (K) & $\operatorname{Lmax}(\mathrm{cd} \mathrm{m-2)}$ & $\eta c(c d A-1)$ & $\begin{array}{l}\text { CQDs } \\
\text { Synthesis } \\
\text { Method }\end{array}$ & Precursors & $\begin{array}{l}\text { Reaction } \\
\text { Conditions }\end{array}$ & $\begin{array}{l}\text { Modifications and } \\
\text { Functionalization }\end{array}$ & Purification & $\begin{array}{l}\text { Average Size } \\
(\mathrm{nm})\end{array}$ & QY (\%) & Ref. \\
\hline LEDs & $\mathrm{n} / \mathrm{a}$ & $1882-4762$ & $1.22-5.11$ & Solvothermal & Phloroglucinol (PG) & $\begin{array}{c}200{ }^{\circ} \mathrm{C}, 2 \mathrm{~h}, 5 \mathrm{~h} \text {, } \\
9 \mathrm{~h} \text {, and } 24 \mathrm{~h}\end{array}$ & $\mathrm{n} / \mathrm{a}$ & $\begin{array}{c}\text { Silica gel column } \\
\text { chromatography } \\
\text { (Dichloromethane } \\
\text { and Methanol } \\
\text { (variable) }\end{array}$ & $1.9-3.9$ & $\begin{array}{l}\text { blue CQDs: } 66 \\
\text { green CQDs: } 72 \\
\text { yellow CQDs: } 62 \\
\text { red CQDs: } 54\end{array}$ & [166] \\
\hline LEDs & 6000 & $\mathrm{n} / \mathrm{a}$ & $\mathrm{n} / \mathrm{a}$ & Reflux & $\begin{array}{l}\text { Diammonium } \\
\text { hydrogen citrate } \\
\text { Urea }\end{array}$ & $180^{\circ} \mathrm{C}, 15 \mathrm{~min}$ & N-doping & $\begin{array}{l}\text { Centrifugation } \\
(6000 \times \text { g rpm, } \\
20 \mathrm{~min})\end{array}$ & $4-10$ & 16 & [167] \\
\hline LEDs & $\mathrm{n} / \mathrm{a}$ & $2-174$ & $\begin{array}{l}9 \times 10^{-4}- \\
2 \times 10^{-3}\end{array}$ & $\begin{array}{l}\text { Hydrothermal } \\
\text { or Hot injection }\end{array}$ & $\begin{array}{c}\text { Citric acid } \\
\text { HDA/urea/EDA/PDA }\end{array}$ & $\begin{array}{l}200^{\circ} \mathrm{C}, 5 \mathrm{~h} \text { or } \\
160^{\circ} \mathrm{C}, 16 \mathrm{~h}\end{array}$ & $\begin{array}{l}\text { N-doping } \\
\text { HDA/EDA/PDA } \\
\text { hybridization }\end{array}$ & $\begin{array}{l}\text { Centrifugation } \\
(4500 \times g \mathrm{rpm}, \\
\text { Time n./a) }\end{array}$ & $3.6,5.4,3.3,31.7$ & $\begin{array}{l}\text { EDA-CQDs: } 43 \\
\text { PDA-CQDs: } 8 \\
\text { HAD-CQDs: } 40 \\
\text { Urea-CQDs: } 35\end{array}$ & [168] \\
\hline LEDs & 2520 & $\mathrm{n} / \mathrm{a}$ & $\mathrm{n} / \mathrm{a}$ & Hydrothermal & $\begin{array}{c}2,7- \\
\text { dihydroxynaphthalene } \\
\text { Ethylenediamine }\end{array}$ & $180^{\circ} \mathrm{C}, 12 \mathrm{~h}$ & N-doping & $\begin{array}{l}\text { Centrifugation } \\
\text { (8000×g rpm, } \\
5 \mathrm{~min})\end{array}$ & 3.31 & 62.98 & [169] \\
\hline LEDs & $\mathrm{n} / \mathrm{a}$ & $\mathrm{n} / \mathrm{a}$ & $\mathrm{n} / \mathrm{a}$ & $\begin{array}{l}\text { Microwave- } \\
\text { assisted }\end{array}$ & $\begin{array}{c}\text { Citric acid } \\
\text { o-Phenylene-diamine } \\
\text { (oPD) }\end{array}$ & $125^{\circ} \mathrm{C}, 5 \mathrm{~min}$ & N-doping & $\begin{array}{l}\text { Dialysis (1000 Da, } \\
\quad 30 \mathrm{~min})\end{array}$ & 1.1 & 5.4 & [38] \\
\hline LEDs & 6250 & $\mathrm{n} / \mathrm{a}$ & $\mathrm{n} / \mathrm{a}$ & Reflux & $\begin{array}{l}\text { Citric acid } \\
\text { Tris-HMA }\end{array}$ & $225^{\circ} \mathrm{C}, 20 \mathrm{~min}$ & $\begin{array}{l}\text { N-doping } \\
\text { Polymer } \\
\text { passivation }\end{array}$ & $\begin{array}{l}\text { Dialysis (1000 Da, } \\
2 \text { days) }\end{array}$ & 3.35 & 23 & [92] \\
\hline LEDs & $3913,5994,10000$ & $\mathrm{n} / \mathrm{a}$ & $\mathrm{n} / \mathrm{a}$ & Solvothermal & $\begin{array}{c}\text { o-Phenylenediamine } \\
\text { 4- } \\
\text { aminobenzenesulfonic } \\
\text { acid } \\
\text { folic acid } \\
\text { boric acid } \\
\text { acetic acid } \\
\text { terephthalic acid } \\
\text { tartaric acid }\end{array}$ & $180^{\circ} \mathrm{C}, 12 \mathrm{~h}$ & N-doping & $\begin{array}{l}\text { Dialysis (MWCO } \\
\mathrm{n} / \mathrm{a} \text {, Time n/a) in } \\
\text { ethanol }\end{array}$ & 3.01 & $\begin{array}{l}\text { b-CQDs: } 25 \\
\text { c-CQDs: } 36 \\
\text { g-CQDs: } 28 \\
\text { yg-CQDs: } 72 \\
\text { y-CQDs: } 45 \\
\text { o-CQDs: } 59 \\
\text { r-CQDs: } 47 \\
\text { dr-CQDs: } 52 \\
\text { w-CQDs: } 39\end{array}$ & [170] \\
\hline
\end{tabular}


Table 5. Cont.

\begin{tabular}{|c|c|c|c|c|c|c|c|c|c|c|c|}
\hline \multicolumn{12}{|c|}{ (B) } \\
\hline Application & $\mathrm{Jsc}(\mathrm{mA} / \mathrm{cm} 2)$ & Voc (V) & $\eta(\%)$ & $\begin{array}{l}\text { CQDs } \\
\text { Synthesis } \\
\text { Method }\end{array}$ & Precursors & $\begin{array}{c}\text { Reaction } \\
\text { Conditions }\end{array}$ & $\begin{array}{l}\text { Modifications and } \\
\text { Functionalization }\end{array}$ & Purification & $\begin{array}{c}\text { Average Size } \\
(\mathrm{nm})\end{array}$ & QY (\%) & Ref. \\
\hline Solar converters & 22.2 & 1.05 & 15 & Hydrothermal & $\begin{array}{l}\text { Citric acid } \\
\text { Urea }\end{array}$ & $200^{\circ} \mathrm{C}, 6 \mathrm{~h}$ & $\mathrm{TiO}_{2}$ & $\begin{array}{l}\text { Wash with } \\
\text { deionized water } \\
\text { and ethanol } \\
\text { numerous times }\end{array}$ & $30-40$ & $\mathrm{n} / \mathrm{a}$ & [171] \\
\hline Solar converters & $\mathrm{n} / \mathrm{a}$ & $\mathrm{n} / \mathrm{a}$ & $\mathrm{n} / \mathrm{a}$ & Hydrothermal & $\begin{array}{c}\text { Citric acid } \\
\text { Ethylenediamine } \\
\text { TRIS }\end{array}$ & $200^{\circ} \mathrm{C}, 6 \mathrm{~h}$ & N-doping & $\begin{array}{l}\text { Dialysis (3000 Da, } \\
2 \mathrm{~h} \text { ) }\end{array}$ & 2 & 50 & [172] \\
\hline Solar converters & $12.67-18.49$ & $0.46-0.48$ & $3.26-4.97$ & $\begin{array}{l}\text { Microwave- } \\
\text { assisted }\end{array}$ & $\begin{array}{l}\text { Citric acid } \\
\text { Urea }\end{array}$ & $800 \mathrm{~W}, 5 \mathrm{~min}$ & N-doping & $\begin{array}{l}\text { Filtration with a } \\
\text { cylinder filtration } \\
\text { membrane filter } \\
(0.22 \mu \mathrm{m})\end{array}$ & 2.9 & 80 & [173] \\
\hline Solar converters & 35.98 & 0.62 & 17.86 & Hydrothermal & $\begin{array}{l}\text { Citric acid } \\
\text { KH-792 } \\
\text { Thiourea }\end{array}$ & $180^{\circ} \mathrm{C}, 12 \mathrm{~h}$ & N-doping & $\begin{array}{l}\text { Wash with hexane, } \\
3 \text { times } \\
\text { Dialysis (MWCO } \\
\text { n/a, } 24 \mathrm{~h} \text { ) }\end{array}$ & $2-3$ & 20.68 & [174] \\
\hline Solar converters & 1.60 & 0.54 & 1.20 & Solvothermal & $\begin{array}{l}\text { Jaggery syrup } \\
\text { Urea }\end{array}$ & $140^{\circ} \mathrm{C}, 2.5 \mathrm{~h}$ & $\mathrm{~N}$-doping & $\begin{array}{c}\text { Centrifugation } \\
(12,000 \times \mathrm{g} \mathrm{rpm} \\
30 \mathrm{~min})\end{array}$ & 9.5 & 9.8 & [176] \\
\hline Solar converters & 4.5 & 0.495 & 1.6 & Hydrothermal & Phloroglucinol & $\begin{array}{r}200^{\circ} \mathrm{C}, 9 \mathrm{~h}+ \\
70^{\circ} \mathrm{C}, 30 \mathrm{~min}\end{array}$ & $\mathrm{n} / \mathrm{a}$ & $\begin{array}{l}\text { Dialysis (1000 Da, } \\
12 \mathrm{~h})\end{array}$ & 1.74 & 40 & [177] \\
\hline
\end{tabular}


Table 6. Summarized examples of carbon quantum dots used for photocatalysis.

\begin{tabular}{|c|c|c|c|c|c|c|c|c|c|c|c|}
\hline $\begin{array}{c}\text { Target/ } \\
\text { Contaminant }\end{array}$ & $\begin{array}{l}\text { Photocatalysis } \\
\text { Mechanism }\end{array}$ & $\begin{array}{l}\text { CQDs } \\
\text { Synthesis } \\
\text { Method }\end{array}$ & $\begin{array}{l}\text { Modifications and } \\
\text { Functionalization }\end{array}$ & Precursors & $\begin{array}{l}\text { Reaction } \\
\text { Conditions }\end{array}$ & Purification & QY (\%) & $\begin{array}{l}\text { Average Size } \\
\text { (nm) }\end{array}$ & Degradation (\%) & $\begin{array}{l}\text { Degradation } \\
\text { Time (min) }\end{array}$ & Ref. \\
\hline $\begin{array}{l}\text { Rhodamine B } \\
\text { Methylene blue }\end{array}$ & $\begin{array}{l}\text { Oxidation by formation } \\
\text { of holes and superoxide } \\
\text { radical anions }\end{array}$ & $\begin{array}{l}\text { Microwave } \\
\text { assisted }\end{array}$ & N-doping & $\begin{array}{c}\text { Citric acid } \\
1,2- \\
\text { Phenylenediamine }\end{array}$ & $700 \mathrm{~W}, 7 \mathrm{~min}$ & $\begin{array}{l}\text { Filtration and } \\
\text { SEC }\end{array}$ & 39.2 & 2 & 70 & 150 & [114] \\
\hline Acid Blue & \multirow{6}{*}{$\begin{array}{l}\text { Formation of reactive } \\
\text { oxide species (ROS) }\end{array}$} & \multirow{6}{*}{ Hydrothermal } & \multirow{6}{*}{ N-doping } & \multirow{6}{*}{ Grass } & \multirow{6}{*}{$180^{\circ} \mathrm{C}, 2 \mathrm{~h}$} & \multirow{6}{*}{$\begin{array}{l}\text { Wash with } \\
\text { distilled water }\end{array}$} & \multirow{6}{*}{$\mathrm{n} / \mathrm{a}$} & \multirow{6}{*}{$<10$} & \multirow{6}{*}{100 (for all) } & 30 & \multirow{6}{*}{ [178] } \\
\hline Acid Red & & & & & & & & & & 30 & \\
\hline Eosin $Y$ & & & & & & & & & & 90 & \\
\hline $\begin{array}{l}\text { Eriochrome } \\
\text { Black T }\end{array}$ & & & & & & & & & & $\begin{array}{l}\text { Immediate } \\
\text { decomposition } \\
\text { no radiation } \\
\text { required }\end{array}$ & \\
\hline Methyl orange & & & & & & & & & & $\begin{array}{l}\text { Immediate } \\
\text { decomposition } \\
\text { no radiation } \\
\text { required }\end{array}$ & \\
\hline Methylene blue & & & & & & & & & & 90 & \\
\hline $\begin{array}{l}\text { Rhodamine B } \\
\text { Methylene Blue }\end{array}$ & $\begin{array}{l}\text { Oxidation by formation } \\
\text { of holes and active } \\
\text { oxygen/hydroxyl } \\
\text { radicals }\end{array}$ & Hydrothermal & $\mathrm{n} / \mathrm{a}$ & Palm powder & $200^{\circ} \mathrm{C}, 7 \mathrm{~h}$ & $\begin{array}{l}\text { Filtration with } \\
\text { membrane filter } \\
(0.22 \mu \mathrm{m}) \\
\text { Dialysis }(500 \mathrm{Da} \\
\text { membrane, } 48 \mathrm{~h})\end{array}$ & 0.9 & 3.54 & $\begin{array}{l}71.7 \text { and } 94.2, \\
\text { respectively }\end{array}$ & 45 (both) & [179] \\
\hline \multirow{6}{*}{ Methyl viologen } & \multirow{6}{*}{$\begin{array}{l}\text { photoinduced electron } \\
\text { transfer }\end{array}$} & \multirow{3}{*}{$\begin{array}{l}\text { Hydrothermal } \\
\text { (for amorphous } \\
\text { synthesis (a-)) }\end{array}$} & \multirow{6}{*}{$\mathrm{n} / \mathrm{a}$} & Citric acid (Cit) & $180^{\circ} \mathrm{C}, 24 \mathrm{~h}$ & - & $1.0 \mathrm{a}-\mathrm{Cit}-\mathrm{CDs}$ & \multirow{3}{*}{$9-12$} & $3.45 \times 10^{-8} \mathrm{M} \mathrm{s}^{-1}$ & \multirow{6}{*}{$\mathrm{n} / \mathrm{a}$} & \multirow{6}{*}{ [180] } \\
\hline & & & & Glucose (Glu) & $200^{\circ} \mathrm{C}, 24 \mathrm{~h}$ & Centrifugation & $1.8 \mathrm{a}-\mathrm{Glu}-\mathrm{CDs}$ & & $0.65 \times 10^{-8} \mathrm{M} \mathrm{s}^{-1}$ & & \\
\hline & & & & Fructose (Fru) & $200^{\circ} \mathrm{C}, 24 \mathrm{~h}$ & $\begin{array}{l}\text { (n/a time) and } \\
\text { Filtration }\end{array}$ & $0.3 \mathrm{a}-\mathrm{Fru}-\mathrm{CDs}$ & & $4.37 \times 10^{-8} \mathrm{M} \mathrm{s}^{-1}$ & & \\
\hline & & \multirow{3}{*}{$\begin{array}{c}\text { Pyrolytic } \\
\text { (for graphitic } \\
\text { synthesis (g-)) }\end{array}$} & & Citric acid (Cit) & $220^{\circ} \mathrm{C}, 48 \mathrm{~h}$ & \multirow{3}{*}{$\begin{array}{c}\text { Dialysis } \\
(1000 \mathrm{Da} \\
\text { membrane, } 24 \mathrm{~h})\end{array}$} & $1.2 \mathrm{~g}-\mathrm{Cit}-\mathrm{CDs}$ & $7-9$ & $5.06 \times 10^{-8} \mathrm{M} \mathrm{s}^{-1}$ & & \\
\hline & & & & Glucose (Glu) & $220^{\circ} \mathrm{C}, 48 \mathrm{~h}$ & & $2.3 \mathrm{~g}$-Glu-CDs & $2-7$ & $1.07 \times 10^{-8} \mathrm{M} \mathrm{s}^{-1}$ & & \\
\hline & & & & Fructose (Fru) & $220^{\circ} \mathrm{C}, 48 \mathrm{~h}$ & & $0.7 \mathrm{~g}$-Fru-CDs & $\begin{array}{l}0.5 \mu \mathrm{m}- \\
1.5 \mu \mathrm{m}\end{array}$ & $0.67 \times 10^{-8} \mathrm{M} \mathrm{s}^{-1}$ & & \\
\hline $\begin{array}{c}\text { Tetracycline } \\
\text { Bisphenol A } \\
\text { Rhodamine B }\end{array}$ & $\begin{array}{l}\text { Direct hole oxidation } \\
\text { reaction }\end{array}$ & Hydrothermal & $\mathrm{n} / \mathrm{a}$ & $\mathrm{n} / \mathrm{a}$ & $\mathrm{n} / \mathrm{a}$ & $\mathrm{n} / \mathrm{a}$ & 80 & 5 & $\begin{array}{c}60 \\
73 \\
91.8\end{array}$ & $\begin{array}{c}120 \\
150 \\
20\end{array}$ & [181] \\
\hline Rose bengal & $\begin{array}{c}\text { Formation of singlet } \\
\text { oxygen }\end{array}$ & $\begin{array}{l}\text { Bottom-up } \\
\text { condensation }\end{array}$ & P-doping & Pluronic F-68 & $\mathrm{n} / \mathrm{a}$ & $\mathrm{n} / \mathrm{a}$ & 31 & $<21$ & 86 & 180 & [182] \\
\hline
\end{tabular}


Table 6. Cont.

\begin{tabular}{|c|c|c|c|c|c|c|c|c|c|c|c|}
\hline $\begin{array}{c}\text { Target/ } \\
\text { Contaminant }\end{array}$ & $\begin{array}{l}\text { Photocatalysis } \\
\text { Mechanism }\end{array}$ & $\begin{array}{l}\text { CQDs } \\
\text { Synthesis } \\
\text { Method }\end{array}$ & $\begin{array}{l}\text { Modifications and } \\
\text { Functionalization }\end{array}$ & Precursors & $\begin{array}{c}\text { Reaction } \\
\text { Conditions }\end{array}$ & Purification & QY (\%) & $\begin{array}{c}\text { Average Size } \\
\text { (nm) }\end{array}$ & Degradation (\%) & $\begin{array}{l}\text { Degradation } \\
\text { Time (min) }\end{array}$ & Ref. \\
\hline $\mathrm{CO}_{2}$ & $\begin{array}{c}\text { Reduction by } \\
\text { accumulated electrons } \\
\text { under the assistance of } \\
\mathrm{H}^{+}\end{array}$ & $\begin{array}{l}\text { Microwave- } \\
\text { assisted }\end{array}$ & N, S-doping & $\begin{array}{l}\text { Citric acid } \\
\text { Thiourea }\end{array}$ & $800 \mathrm{~W}, 7 \mathrm{~min}$ & $\begin{array}{l}\text { Dialysis } \\
(\mathrm{MWCO} \mathrm{n} / \mathrm{a} \\
24 \mathrm{~h})\end{array}$ & $\mathrm{n} / \mathrm{a}$ & 3.5 & $\mathrm{n} / \mathrm{a}$ & 360 & [183] \\
\hline Tetracycline & $\begin{array}{l}\text { Oxidation by formation } \\
\text { of holes and superoxide } \\
\text { radical anions }\end{array}$ & Hydrothermal & N-doping & $\begin{array}{l}\text { Ammonium citrate } \\
\text { Ethylenediamine }\end{array}$ & $200^{\circ} \mathrm{C}, 5 \mathrm{~h}$ & $\begin{array}{c}\text { Dialysis } \\
\text { (1000 Da, 24 h) }\end{array}$ & $\mathrm{n} / \mathrm{a}$ & 8 & 97 & 25 & [184] \\
\hline $\begin{array}{l}\text { Crystal violet } \\
\text { dye }\end{array}$ & $\begin{array}{l}\text { Oxidation by formation } \\
\text { of holes and } \\
\text { photo-generated } \\
\text { electrons }\end{array}$ & $\begin{array}{l}\text { Hydrothermal } \\
\text { and mixed- } \\
\text { calcination }\end{array}$ & $\mathrm{n} / \mathrm{a}$ & $\begin{array}{l}\text { Ascorbic acid } \\
\text { Glycol }\end{array}$ & $160^{\circ} \mathrm{C}, 70 \mathrm{~min}$ & $\mathrm{n} / \mathrm{a}$ & $\mathrm{n} / \mathrm{a}$ & $4-9$ & 70 & 300 & [185] \\
\hline Amoxicillin & $\begin{array}{l}\text { Oxidation by formation } \\
\text { of holes and hydroxyl } \\
\text { radicals }\end{array}$ & $\begin{array}{l}\text { Hydrothermal } \\
\text { and calcination }\end{array}$ & $\begin{array}{l}\text { potassium titanate } \\
\qquad\left(\mathrm{K}_{2} \mathrm{Ti}_{6} \mathrm{O}_{13}\right)\end{array}$ & $\mathrm{n} / \mathrm{a}$ & $\mathrm{n} / \mathrm{a}$ & $\mathrm{n} / \mathrm{a}$ & 80 & $\mathrm{n} / \mathrm{a}$ & 100 & 90 & [186] \\
\hline Sulfamethazine & $\begin{array}{l}\text { Oxidation by formation } \\
\text { of holes, superoxide } \\
\text { radical anions and } \\
\text { photo-generated } \\
\text { electrons }\end{array}$ & Calcination & N-doping & $\begin{array}{l}\text { Citric acid } \\
\text { Urea }\end{array}$ & $550^{\circ} \mathrm{C}, 3 \mathrm{~h}$ & $\mathrm{n} / \mathrm{a}$ & $\mathrm{n} / \mathrm{a}$ & $2-5$ & 97.3 & 50 & [187] \\
\hline \multirow{3}{*}{ Indigo carmine } & \multirow{3}{*}{$\begin{array}{l}\text { Oxidation by formation } \\
\text { of holes and } \\
\text { photo-generated } \\
\text { electrons }\end{array}$} & \multirow{3}{*}{ Solvothermal } & \multirow{3}{*}{ N-doping } & Aniline & \multirow{3}{*}{$180^{\circ} \mathrm{C}, 10 \mathrm{~h}$} & \multirow{3}{*}{$\begin{array}{c}\text { Centrifugation } \\
\text { (10 000 } \times \text { g rpm, } \\
5 \mathrm{~min}) \\
\text { Dialysis } \\
(3500 \mathrm{Da}, 24 \mathrm{~h})\end{array}$} & 0.25 & 2.0 & \multirow{3}{*}{97} & \multirow{3}{*}{120} & \multirow{3}{*}[188]{} \\
\hline & & & & 2-anthracylamine & & & 0.28 & 2.6 & & & \\
\hline & & & & 1-aminopyrene & & & 0.14 & 2.2 & & & \\
\hline $\begin{array}{l}\text { Benzene } \\
p \text {-xylene } \\
\text { Toluene }\end{array}$ & $\begin{array}{c}\text { CQDs } / \mathrm{TiO}_{2} \\
\text { nanocomposites } \\
\text { improved interfacial } \\
\text { charge transfer; } \\
\text { increased light } \\
\text { absorption; narrower } \\
\text { bandgap }\end{array}$ & Pyrolysis & $\begin{array}{c}\mathrm{CQDs} / \mathrm{TiO}_{2} \\
\text { nanocomposites }\end{array}$ & Citric acid & $180^{\circ} \mathrm{C}, 40 \mathrm{~h}$ & $\mathrm{n} / \mathrm{a}$ & $\mathrm{n} / \mathrm{a}$ & 2.4 & $\begin{array}{l}31 \\
64 \\
99\end{array}$ & 140 & [189] \\
\hline
\end{tabular}


Table 7. Summarized examples of carbon quantum dots used as antimicrobials and antivirals.

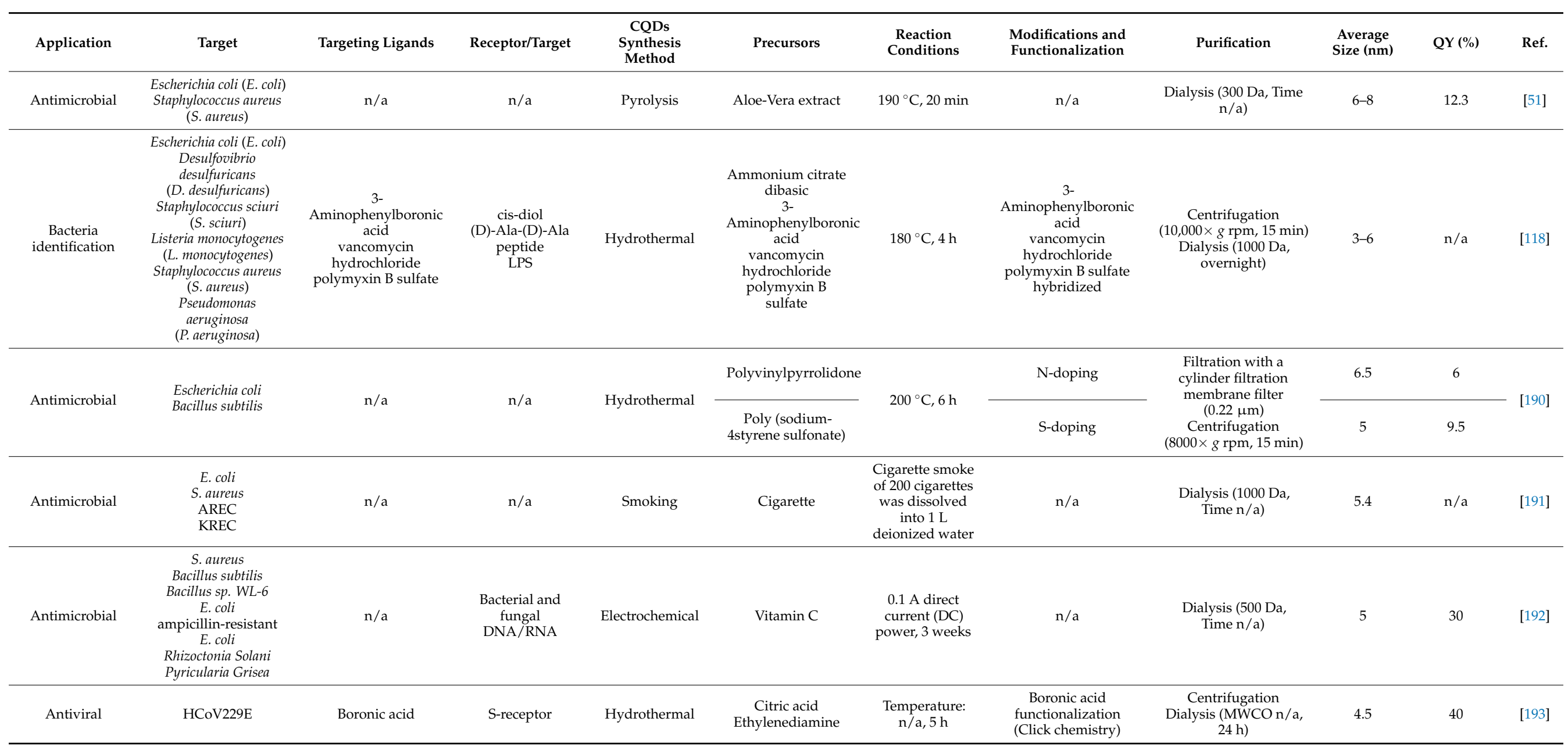


Table 7. Cont

\begin{tabular}{|c|c|c|c|c|c|c|c|c|c|c|c|}
\hline Application & Target & Targeting Ligands & Receptor/Target & $\begin{array}{l}\text { CQDs } \\
\text { Synthesis } \\
\text { Method }\end{array}$ & Precursors & $\begin{array}{l}\text { Reaction } \\
\text { Conditions }\end{array}$ & $\begin{array}{l}\text { Modifications and } \\
\text { Functionalization }\end{array}$ & Purification & $\begin{array}{c}\text { Average } \\
\text { Size (nm) }\end{array}$ & QY (\%) & Ref. \\
\hline Antiviral & $\begin{array}{c}\text { Japanese encephalitis } \\
\text { Zika } \\
\text { Dengue } \\
\text { Porcine parvovirus } \\
\text { Adenovirus- } \\
\text { associated } \\
\text { virus }\end{array}$ & $\mathrm{n} / \mathrm{a}$ & $\mathrm{n} / \mathrm{a}$ & Hydrothermal & $\begin{array}{l}\text { Benzoxazine monomers } \\
\text { (BZM) }\end{array}$ & $180^{\circ} \mathrm{C}, 12 \mathrm{~h}$ & $\mathrm{n} / \mathrm{a}$ & $\begin{array}{c}\text { Centrifugation } \\
(10,000 \times g \mathrm{rpm}, 10 \mathrm{~min}) \\
\text { Dialysis }(\mathrm{MWCO} \mathrm{n} / \mathrm{a} \\
\text { Time n/a) }\end{array}$ & 4.4 & 13.1 & [194] \\
\hline Antiviral & $\begin{array}{l}\text { Porcine reproductive } \\
\text { Respiratory } \\
\text { syndrome virus } \\
\text { (PRRSV) }\end{array}$ & Glycyrrhizic acid & $\mathrm{n} / \mathrm{a}$ & Hydrothermal & Glycyrrhizic acid & $180^{\circ} \mathrm{C}, 7 \mathrm{~h}$ & $\mathrm{n} / \mathrm{a}$ & $\begin{array}{c}\text { Centrifugation } \\
(10,000 \times g \mathrm{rpm}, 10 \mathrm{~min}) \\
\text { Dialysis }(14,000 \mathrm{Da}, 8 \mathrm{~h})\end{array}$ & 11.4 & 1.41 & [195] \\
\hline Antiviral & $\begin{array}{c}\text { White spot syndrome } \\
\text { virus (WSSV) }\end{array}$ & $\mathrm{n} / \mathrm{a}$ & $\mathrm{n} / \mathrm{a}$ & $\mathrm{n} / \mathrm{a}$ & Polyamine & $\mathrm{n} / \mathrm{a}$ & $\mathrm{n} / \mathrm{a}$ & $\mathrm{n} / \mathrm{a}$ & $\mathrm{n} / \mathrm{a}$ & $\mathrm{n} / \mathrm{a}$ & [196] \\
\hline \multirow{5}{*}{ Antimicrobial } & \multirow{5}{*}{ Bacillus subtilis } & \multirow{5}{*}{$\mathrm{n} / \mathrm{a}$} & \multirow{5}{*}{$\mathrm{n} / \mathrm{a}$} & \multirow{4}{*}{$\begin{array}{l}\text { Reflux in } \\
\text { concentrated } \\
\text { nitric acid }\end{array}$} & \multirow{4}{*}{ Carbon nano-powders } & \multirow{4}{*}{$\begin{array}{c}\text { Temp }\left({ }^{\circ} \mathrm{C}\right) \mathrm{n} / \mathrm{a} \\
48 \mathrm{~h}\end{array}$} & EDA: EDA-CDots & \multirow{4}{*}{$\begin{array}{l}\text { Dialysis }(500 \mathrm{Da}, 48 \mathrm{~h}) \\
\quad \text { Centrifugation } \\
(1000 \times \mathrm{g}, \text { time n/a) }\end{array}$} & $4-5$ & 20 & \multirow{5}{*}{ [81] } \\
\hline & & & & & & & EPA: EPA-CDots & & $4-5$ & 20 & \\
\hline & & & & & & & $\begin{array}{c}\text { PEI }_{1200}: \\
\text { PEI }_{1200} \text {-CDots }\end{array}$ & & $4-6$ & 12 & \\
\hline & & & & & & & $\mathrm{PEI}_{600}$ : $\mathrm{PEI}_{600}$-CDots & & $\mathrm{n} / \mathrm{a}$ & $\mathrm{n} / \mathrm{a}$ & \\
\hline & & & & Hydrothermal & $\begin{array}{l}\text { Citric acid } \\
\text { PEI }_{1200}\end{array}$ & $\mathrm{n} / \mathrm{a}$ & $\begin{array}{l}\mathrm{PEI}_{1200} / \mathrm{CA}-C D o t s-1 \\
\mathrm{PEI}_{1200} / \mathrm{CA}-C D o t s-2 \\
\mathrm{PEI}_{1200} / \mathrm{CA}-C D o t s-3 \\
\end{array}$ & $\mathrm{n} / \mathrm{a}$ & 10 & 60 & \\
\hline Antimicrobial & $\begin{array}{c}\text { Fusarium oxysporum } \\
\text { S. aureus } \\
\text { P. aeruginosa } \\
\text { B. subtilis } \\
\text { E. coli } \\
\text { MCF-7 } \\
\text { HepG2 cells } \\
\end{array}$ & $\mathrm{n} / \mathrm{a}$ & $\mathrm{n} / \mathrm{a}$ & $\begin{array}{l}\text { Microwave- } \\
\text { assisted }\end{array}$ & $\begin{array}{c}\text { Pomegranate extract } \\
\text { Watermelon extract } \\
\text { PEG } 200\end{array}$ & $\begin{array}{l}\text { Microwave } \\
\text { radiation for } \\
2 \text { min at the } \\
\text { interval of } 10 \mathrm{~s} \\
\text { each }\end{array}$ & Polymer passivation & $\mathrm{n} / \mathrm{a}$ & $1-5$ & $\mathrm{n} / \mathrm{a}$ & [131] \\
\hline Antibacterial & $\begin{array}{l}\text { Staphyloccocus aureus } \\
\text { Escherichia coli }\end{array}$ & Polyurethane (PU) & $\mathrm{n} / \mathrm{a}$ & $\begin{array}{l}\text { Swell } \\
\text { encapsulation- } \\
\text { shrink method } \\
\text { (hCQDss/PU) }\end{array}$ & Pluronic F-68 & $\begin{array}{c}\text { ambient } \\
\text { temperature, } \\
48 \mathrm{~h}\end{array}$ & $\mathrm{n} / \mathrm{a}$ & $\mathrm{n} / \mathrm{a}$ & $\mathrm{n} / \mathrm{a}$ & $\mathrm{n} / \mathrm{a}$ & [182] \\
\hline Antiviral & $\begin{array}{l}\text { avian leukosis virus } \\
\text { subgroup J (ALV-J) }\end{array}$ & gp85 protein & $\mathrm{n} / \mathrm{a}$ & Hydrothermal & $\begin{array}{c}\text { Humic acid } \\
\text { polytetrafluoroethylene }\end{array}$ & $180^{\circ} \mathrm{C}, 5 \mathrm{~h}$ & gp85 protein & $\begin{array}{c}\text { Centrifugation } \\
(3000 \times g \text { rpm, } 15 \mathrm{~min}) \\
\text { Dialysis }(1000 \mathrm{Da}, 48 \mathrm{~h}) \\
\text { Centrifugation } \\
(12,000 \times \mathrm{g} \mathrm{rpm}, 15 \mathrm{~min})\end{array}$ & $3-5$ & $\mathrm{n} / \mathrm{a}$ & [197] \\
\hline
\end{tabular}


Table 7. Cont.

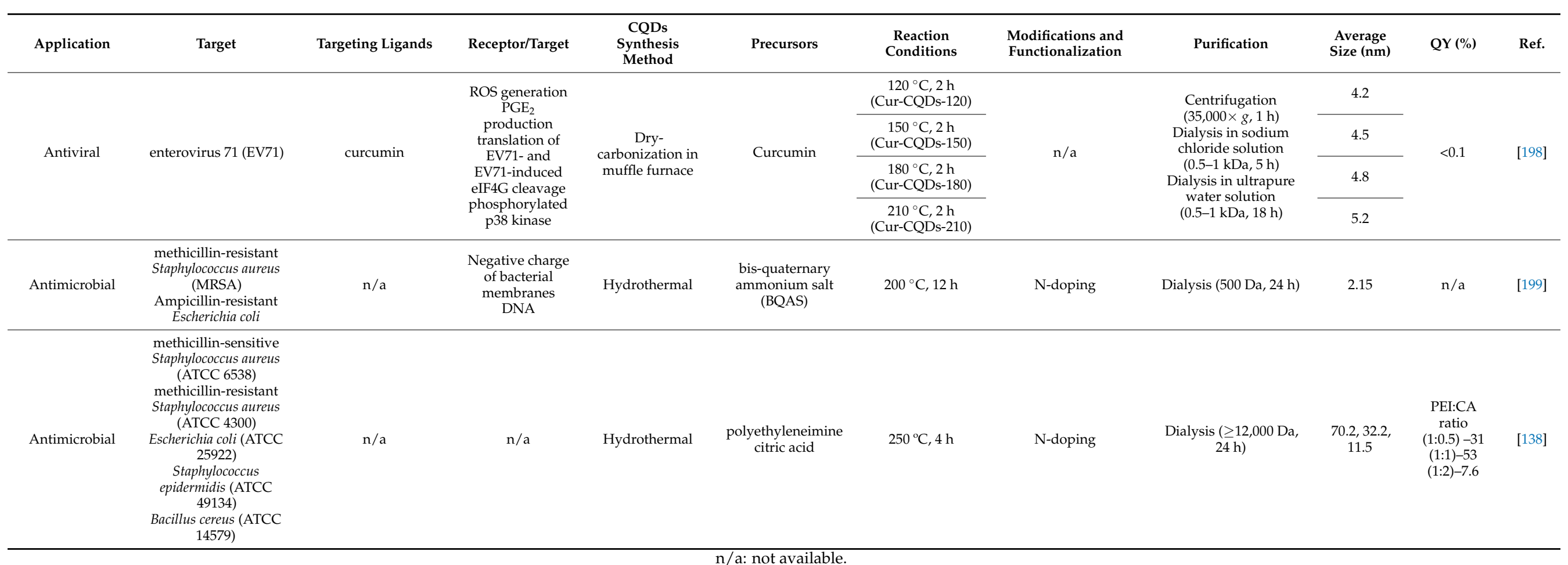




\subsection{Biomedical}

\subsubsection{Bioimaging}

Fluorescence-based bioimaging has been sparking interest due mostly to its capacity for full-color imaging coupled with exceptional sensitivity (Table 3). Considering the systems in which such a platform is to be employed, the requirements for fluorescence imaging agents generally comprise low to inexistent toxicity, water solubility, and adequate physical/chemical properties. Thus, CQDs are the ideal nanosystem to succeed metallic semi-conductor QDs, generally regarded as quite toxic [200].

In 2019, Zheng et al. [118] synthesized CQDs through a one-pot synthesis using ammonium citrate dibasic mixed with either 3-aminophenylboronic acid, vancomycin hydrochloride, or polymyxin B sulfate to produce BA-CQDs, Van-CQDs, and PM-CQDs. The as-synthesized CQDs were then employed in the imaging and identification of six bacteria species: Escherichia coli (E coli.), Desulfovibrio desulfuricans (D. desulfuricans), Staphylococcus sciuri (S. sciuri), Listeria monocytogenes (L. monocytogenes), Staphylococcus aureus (S. aureus), and Pseudomonas aeruginosa (P. aeruginosa). The three recognition molecules utilized in CQDs synthesis could bind to all the bacteria with different abilities due to the variety of physicochemical nature of the different bacteria surfaces. Boronic acid CQDs presented the boronic acid ability to interact with cis-diol molecules present on the cell wall of bacteria, polymyxin CQDs manifested high affinity to lipopolysaccharide (LPS) molecules on the surface of bacteria, and vancomycin derived CQDs bonded specifically to (D)-Ala-(D)-Ala peptide found in the peptidoglycan layer on bacterial cell walls. Thus, using the mathematical statistical method "linear discriminant analysis" (LDA), the fluorescence pattern resulting from the mentioned interactions provided a good discrimination of the six kinds of bacteria with $91.6 \%$ correct accuracy and the classification of the bacteria according to the gram status of bacteria. Yang et al. [119] prepared CQDs via hydrothermal method from quercetin and ethylenediamine. The CQDs displayed $\mathrm{pH}$-sensitive fluorescence effect under acidic and alkaline conditions and were, therefore, applied as a fluorescent sensor to monitor intracellular $\mathrm{pH}$. The "OFF-ON-OFF" detection of $\mathrm{pH}$ values was based on the quenching of CQDs native fluorescence triggered by $\mathrm{pH}$-induced aggregation. The fluorometric assay was also utilized for the detection of aspartic acid and glutamic acid, based on their isoelectric points. In 2020, Zhong et al. [120] produced blood compatible N,S-CQDs by hydrothermal synthesis from $m$-phenylenediamine and tobias acid. Characterization studies revealed a QY of $37.2 \%$. In vitro studies were later performed to establish N,S-CQDs cytotoxicity towards human umbilical vein endothelial cells (HUVECs). Both confocal microscopy and flow analysis verified that N,S-CDs were efficiently taken up by HUVECs and were afterward localized in the cytoplasm, without considerable cytotoxicity. Additionally, hemolysis rates were determined to be inferior to $0.5 \%$ after exposure to different N,S-CQDs, suggesting blood compatibility. Shi et al. [121] reported the fabrication of red emissive CQDs from $p$-phenylenediamine by hydrothermal synthesis. The as-prepared CQDs were utilized as fluorescent nanoprobes for real-time sensing polarity in living cells based on the red shift of fluorescence emission wavelength verified in the presence of increasing polarity. The photoluminescence color of the CQDs varied from 525 to $612 \mathrm{~nm}$ in solvents with increasing polarity, and an 11-fold decrease in fluorescence intensity was verified when the solvent changed from $10 \%$ to $99 \%$ water. Moreover, the polarity assay was applied to different cell lines for the evaluation of intracellular polarity. Additionally, the CQDs were able to distinguish cancer cells from normal cells and displayed dual targetability both to mitochondria and lysosomes.

\subsubsection{Drug Delivery}

A major requirement for safe drug delivery nano-vehicles is biocompatibility. Although in the past nano-drug delivery systems (DDSs) made use of chalcogenide-based quantum dots (QDs), toxicity and photobleaching presented themselves as impediments to this kind of nanosystem. Consequently, an alternative was needed, and considering CQDs with innate biocompatibility and properties, they have been extensively exploited in drug 
delivery systems, particularly those that combine both diagnostic and therapeutic capabilities [201,202]. Additionally, CQDs exhibit a high modification capability, a feature relevant considering that cellular internalization of drug delivery systems is improved by active targeting, for example, by promoting the interaction between overly expressed receptors on a cell surface and the targeting ligands that were incorporated on CQDs surface. Still, such an approach is not without flaws, and early clearance of CQDs from the bloodstream, causing a decrease in CQDs half-life, may occur due to recognition of target ligands by the mononuclear phagocyte system (MPS) or direct opsonization. Therefore, changes in the extracellular environment such as $\mathrm{pH}$ variations and altered enzyme expression can be the backbone for a triggered targeting approach, in which the target ligands are exposed by the effect of those changes in the extracellular environment, favoring the interaction with the desired receptors on the target cell [201].

Table 2 contains summarized a compilation of some works in which CQDsS were used and drug delivery vehicles. Sun et al. [122] obtained CQDs using sodium citrate dehydrate and urea by a one-step controlled thermal pyrolysis. Afterward, doxorubicin was non-noncovalently conjugated with CQDs by continuous stirring for $48 \mathrm{~h}$ in the dark. The DOX-CQDs were then capable of acid-triggered intracellular release of doxorubicin upon intracellular $\mathrm{pH}$ value changes, reacting to endo-/lysosomal $\mathrm{pH}$ to release the DOX within the cells in vitro and in vivo (Figure 11). Additionally, due to DOX-CQDs optical properties, the release of DOX was monitored, demonstrating inhibition to the proliferation of HO-8910 cells. In vivo, long-term toxicity tests did not reveal significant toxic effects in DOX-CQDs treated mice.

(A)

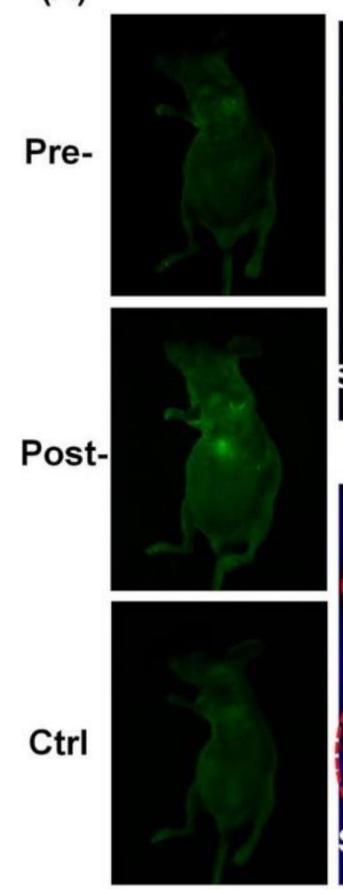

(B)

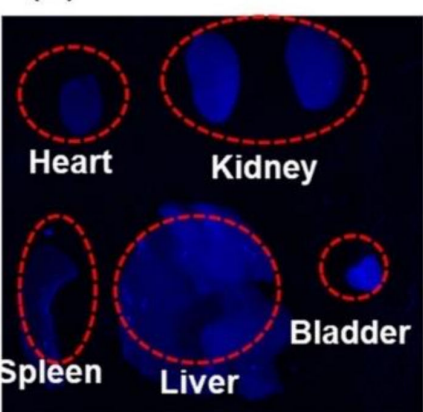

$1 \mathrm{~h}$

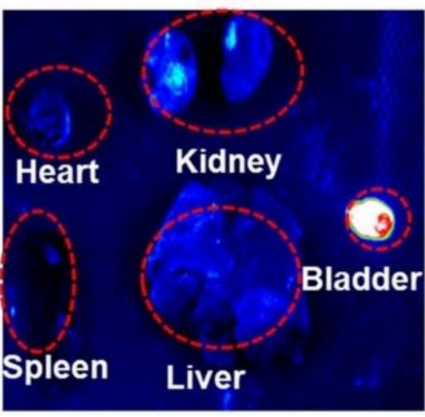

$\mathbf{O} \mathbf{h}$

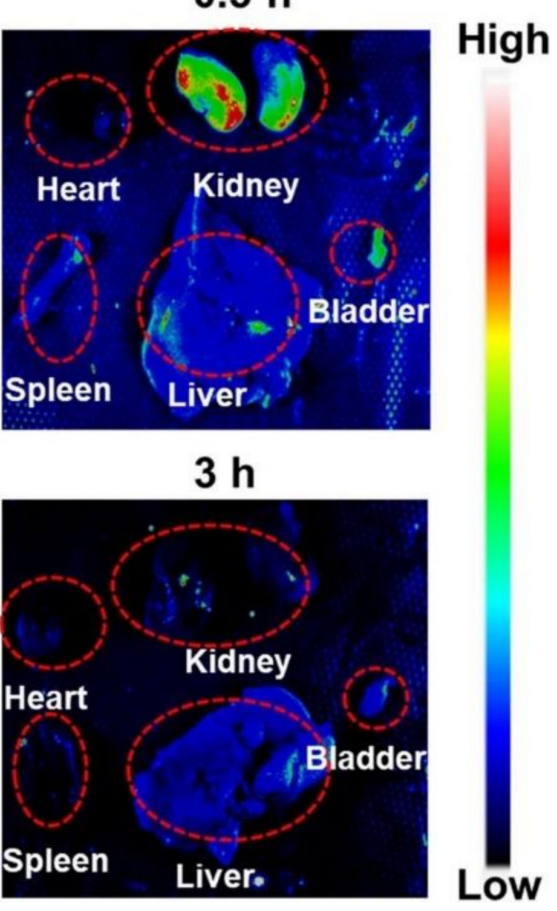

Figure 11. (A) In vivo imaging and (B) ex vivo imaging of a mice after intravenous injection of CQDs. Reproduced with permission from ref. [122], published by Springer Open, 2020.

In 2020, Li et al. [123] prepared hyaluronic acid-modified CQDs (HA-CQDs) by onestep hydrothermal synthesis. Citric acid and branch-PEI were used as core carbon sources. The as-synthesized CQDs were then functionalized with hyaluronic acid for CD44 targeting (HA-CQDs). Afterward, doxorubicin was loaded onto the HA-CQDs, forming HA-CQDs@p-CBA-DOX through an acid cleavable bond, which caused drug-release in a pH-responsive manner. HA-CQDs@p-CBA-DOX exhibited good hemocompatibility 
and serum stability in in vitro experiments, while displaying elevated cytotoxicity on the target cells, 4T1 cells. The HA-CQDs@p-CBA-DOX was internalized by 4T1 cells through a hyaluronic acid-mediated CD44-targeting effect, leading to an augmented in vivo tumor accumulation of HA-CQDs@p-CBA-DOX, which was monitored by live imaging. Duan et al. [124] synthesized hyaluronic acid and heparin functionalized CQDs for the design of a drug delivery system, to target and inhibit the growth and migration of cancerous cells. The plain CQDs were obtained by dissolving glucose in a hydroglycolic solution, and after an initial hydrothermal treatment, PEI solution was added, and the hydrothermal treatment resumed. Then, hyaluronic acid and heparin were immobilized on the surface of CQDs via EDC/EHS coupling. Then, to obtain CQDs-HA-Hep/DOX, doxorubicin solutions at different concentrations were mixed with CQDs-HA-Hep solution at $\mathrm{pH}$ 7.4. The developed nanosystem was evaluated for in vitro drug release curve, blood compatibility, and cell viability, displaying blood compatibility with active targeting and release.

Hettiarachchi et al. [125] designed a triple conjugated system with ultrasmall CQDs with an average size of 1.5-1.7 nm. CQDs were prepared using carbon nanopowder mixed with sulfuric acid and nitric acid by reflux method. Then, CQDs conjugated with transferrin (the targeted ligand) and two anti-cancer drugs, epirubicin and temozolomide, by EDC/EHS coupling. The average size of the obtained nanosystem was only $3.5 \mathrm{~nm}$, allowing efficient blood-brain barrier crossing. In vitro studies were performed with the cell lines SJGBM2, CHLA266, CHLA200 (pediatric), and U87 (adult) to assess the efficacy of the triple conjugated system compared to dual conjugated systems, non-transferrin C-dots-drugs, and free drug combinations. It was demonstrated that the triple conjugated system not only increased the cytotoxicity, but also the two-drug combination displayed the synergistic effect that caused $86 \%$ cytotoxicity to SJGBM2 cells.

\subsubsection{Gene Therapy/Delivery}

Gene therapy relies on the treatment of both acquired and inherited genetic disorder diseases, by transporting genetic material into target cells to obtain either the augmentation of gene expression (as in DNA transfection) or the inhibition of target proteins by utilizing mechanisms such as small interfering RNA (siRNA) transfection. However, the physical and chemical nature of nucleic acids, mainly their fragility towards nucleases and their polyanionic nature that complicates cell approaching due to the negative potential of the cell membrane surface, calls for adequate carriers. While viral vectors provide for superior efficiency of gene delivery, the mass-production of these systems is not yet feasible. Therefore, the development of CQDs as non-viral carriers for gene delivery has been entailed, since it overcomes uneconomical and ineffective preparation and does not rely on scarce or intrinsically toxic elements [203]. Plus, the usage of CQDs in gene therapy provides the opportunity to follow the process of gene delivery, since it allows for the direct tracking of the fluorescent nanosystems, due to the intrinsic optical properties of CQDs [204].

Table 2 contains the most important aspects of some works found in the literature describing the use of CQDs for gene therapy or delivery. Shu et al. [126] developed a combination of CQDs/HER3 siRNA and trastuzumab for dual-targeted therapy in HER2-positive breast cancer cells, to overcome resistance to trastuzumab monotherapy. The CQDs were manufactured from citric acid monohydrate and ethanediamine through hydrothermal synthesis and were functionalized with branched PEI by EDC/EHS coupling. The resulting CQDs were positively charged, which allowed for efficient HER3 siRNA oligomer loading via electrostatic adsorption, forming CQDs/HER3 siRNA complexes. The transfection of CQDs and HER3 siRNA complexes caused the downregulation of HER3 protein expression, triggering considerable cell growth inhibition in BT-474 cells. Either CQDs/HER3 siRNA complexes or trastuzumab individually induced G0/G1 cell cycle arrest, but the combined treatment of CQDs/HER3 siRNA complexes and trastuzumab promoted much-marked cell growth suppression in BT-474 cells. Chen et al. [129] produced a CQDs based multifunctional gene delivery system with CQDs prepared by hydrothermal 
treatment of PEI 600 dissolved in ethanol. The obtained CQDs were modified with various hydrophobic chains and distinct degrees of substitution resorting to an epoxide ringopening reaction. Then, the CQDs were employed as dual-functional non-viral gene vectors, in which the type and degree of substitution of the hydrophobic chain had a major impact on CQDs transfection efficiency. The as-prepared CQDs provided the advantage of being considerably less cytotoxic and presenting a better serum tolerance than classic cationic polymeric gene vectors. Ju et al. [130] synthesized CQDs for the specific inhibition of viral miRNAs by CQDs-mediated delivery of locked nucleic acid (LNA)-based suppressors. The CQDs were obtained by a microwave-assisted pyrolysis of citric acid and branched polyethyleneimine (PEI). Then, CQDs/LNA complexes were formed through electrostatic interaction between CQDs, which were positively charged, and the negatively charged LNA. The combination of CQDs / LNA caused the knockdown of KSHV miR-K1, miR-K4, and miR-K11 levels, inducing apoptosis and proliferation inhibition of KSHV-positive lymphoma cells by the activation of cleaved caspase 3. Additionally, effective inhibition of the initiation of the primary effusion lymphoma in the mouse model was accomplished, as well as induction of tumor regression, greatly improving survival rates.

\subsubsection{Others}

Besides the previous biomedical applications, other examples closely related can be found in the literature, and these are included in Table 2. Jin et al. [127] produced CQDs using ascorbic acid and polyethyleneimine (PEI) by a one-step microwave-assisted method to evaluate the synthesized CQDs ability to affect pre-osteoblasts and determine the mechanism of the effects in vitro and in vivo. Osteogenic differentiation experiments and bone regeneration assays in vivo revealed that not only did CQDs increase the expression of bone-related factors, BSP and OCN, promoting pre-osteoblast differentiation in vitro, but they were also responsible for the promotion of bone regeneration in vivo. Pre-osteoblast differentiation was correlated to intracellular calcium increase, which leads to the induction of ER stress that caused the activation of PERK-eIF2 $\alpha$ ATF4 signaling pathway, promoting the up-regulation of transcription factor ATF4, causing the increase in bone-related factors. In 2018, Malishev et al. [128] demonstrated for the first time the effect of chiral CQDs upon the aggregation process of amyloid beta-42 (A 342$)$, a major constituent of amyloid plaques. CQDs were prepared either from L-lysine or D-lysine by a single-step carbonization procedure. The chiral CQDs, especially L-Lys-CQDs, presented high affinity to A $\beta 42$ in both the monomeric and/or pre-fibrillar species and generated a modulation in the process of fibril assembly of $A \beta 42$, interfered with their membrane interactions, and diminished the cytotoxicity of $A \beta 42$. Wu et al. [144] designed a two-photon fluorescent probe composed of red emissive CQDs, graphene oxide (GO), and azobenzene (Azo) incorporated DNA (DNAAzo) for in-situ imaging of miR-9 in Alzheimer's disease mice living neurons and brains tissues. The prepared fluorescent probe was highly selective and sensitive towards miR-9, exhibiting a limit of detection of $0.57 \mathrm{fm}$. Moreover, it was revealed that miR-9 suffered up-regulation in Alzheimer's disease of early-onset and that it was down-regulated to lower-than-normal levels in the late-onset of Alzheimer's disease. Additionally, the twophoton fluorescent probe was tested as an alternative approach for imaging other miRNAs and medical pathological observation in ex-vivo biopsy.

\subsection{Chemical Sensing}

CQDs are recognized as exceptional sensors for both electrophilic and nucleophilic substances due to their extremely effective charge transfer quenching of fluorescence emission [205].

The application of CQDs to chemical sensing, either of biological molecules or inorganic compounds, relies on photophysical mechanisms, such as Förster resonance energy transfer (FRET), photoinduced electron transfer (PET), metal-ligand charge transfer (MLCT), electronic energy transfer (EET), intramolecular charge transfer (ICT), or twisted intramolecular charge transfer (TICT) [206]. Generally, the interaction between CQDs and 
the target compound is crucial to the sensing process, and as such, the distance between these two components of the process and complementary geometry are two parameters that directly impact the efficiency of the procedure.

Besides the referred photophysical mechanisms, the inner filter effect (IFE) can also be utilized to avoid some practical restrictions that may arise in those fluorescent assays. This process is prompted by the absorption of either exciting and/or emitted light by absorbers, which leads to an augmentation of sensitivity, since there is an exponential correlation between changes in the absorbance of sensors and changes in fluorescence intensity [207].

In Table 4 can be found the compilation of important data related to works found in the scientific literature, as examples of the chemical sensing application of CQDs, for biological molecules and ion sensing. These will be better discussed in the following.

\subsubsection{Biological Molecules}

Zhang et al. [145] produced nitrogen-doped carbon dots (N-CQDs) for the determination of thiourea by a one-step hydrothermal method, using ammonium citrate and dextrin as precursors. Then, a known volume of $\mathrm{Hg}^{2+}$ in Britton-Robinson (BR) buffer solution was added to N-CQDs, triggering N-CQDs' fluorescence quenching. However, the addition of thiourea promoted fluorescence recovery, since the interaction between thiourea and $\mathrm{Hg}^{2+}$ is stronger, therefore producing a fluorescent sensor based on the reversion of fluorescence quenching. Recovered fluorescence and concentration of thiourea exhibited a good linear correlation within the range of $0.90-10.0 \mathrm{mmol} \mathrm{L}^{-1}$. Thiourea determination was performed in tap water, lake water, and rice flour products with a detection limit of $0.15 \mathrm{mmol} \mathrm{L}^{-1}$. In 2020, Ma et al. [146] have developed B-doped CQDs (B-CQDs) as a signal-OFF-ON probe for catechol and glutathione detection. Catechol determination was based on fluorescence quenching, whereas glutathione sensing was achieved through fluorescence recovery without the need for auxiliary reagents. B-CQDs were manufactured through hydrothermal synthesis from citric acid and sodium tetraphenylborate and exhibited a QY of $42 \%$. The linear range for catechol was $1-50 \mathrm{nmol} \mathrm{L}{ }^{-1}$ and the detection limit was $0.25 \mathrm{nmol} \mathrm{L}^{-1}$, under optimum conditions. For glutathione sensing, the linear range was 2-100 nmol L ${ }^{-1}$ and a detection limit of $0.5 \mathrm{nmol} \mathrm{L}{ }^{-1}$. The developed methodology displayed high selectivity for both catechol and glutathione sensing, even in the presence of a high concentration of interferents (biological thiols and amino acids). Thus, B-CQDs were employed in the detection of catechol and glutathione in river water and human serum, respectively. Wang et al. [147] developed a chemiluminescence (CL) system comprised of lucigenin (LUC) and CQDs for the detection of L-cysteine (Cys). The CQDs were prepared via hydrothermal treatment of starch and exhibited an absorption peak at $260 \mathrm{~nm}$ and a fluorescence emission peak centered at $524 \mathrm{~nm}$ (photo-excited at $470 \mathrm{~nm}$ ). While the lucigenin- $\mathrm{H}_{2} \mathrm{O}_{2} \mathrm{CL}$ system is very efficient, some disadvantages can be pointed out, such as insufficient stability and poor selectivity. Thus, CQDs were incorporated in the system, causing a strong enhancement of CL of lucigenin in alkaline media, while still retaining lucigenin as the luminophore. The enhancement was attributed to CQDs operation as electron donors, reacting with dissolved oxygen originating the superoxide anion radical $\left(\mathrm{O}_{2}{ }^{--}\right)$in an alkaline medium, which in turn will react with $\mathrm{Luc}^{\bullet+}$, forming lucigenin dioxetane $\left(\mathrm{LucO}_{2}\right)$ that will be decomposed to excited $\mathrm{NMA}^{*}$, causing light emission from the transition of $\mathrm{NMA}^{*}$ to NMA. L-cysteine enhances blue CL of the developed system linearly in the 10.0 to $100 \mu \mathrm{mol} \mathrm{L}{ }^{-1}$ Cys concentration range, and a detection limit of $8.8 \mu \mathrm{mol} \mathrm{L}{ }^{-1}$ was revealed, allowing for the sensitive determination of L-cysteine. The developed system was then used as a probe for dopamine and alpha lipoic acid, through the mechanism represented in Figure 12. 


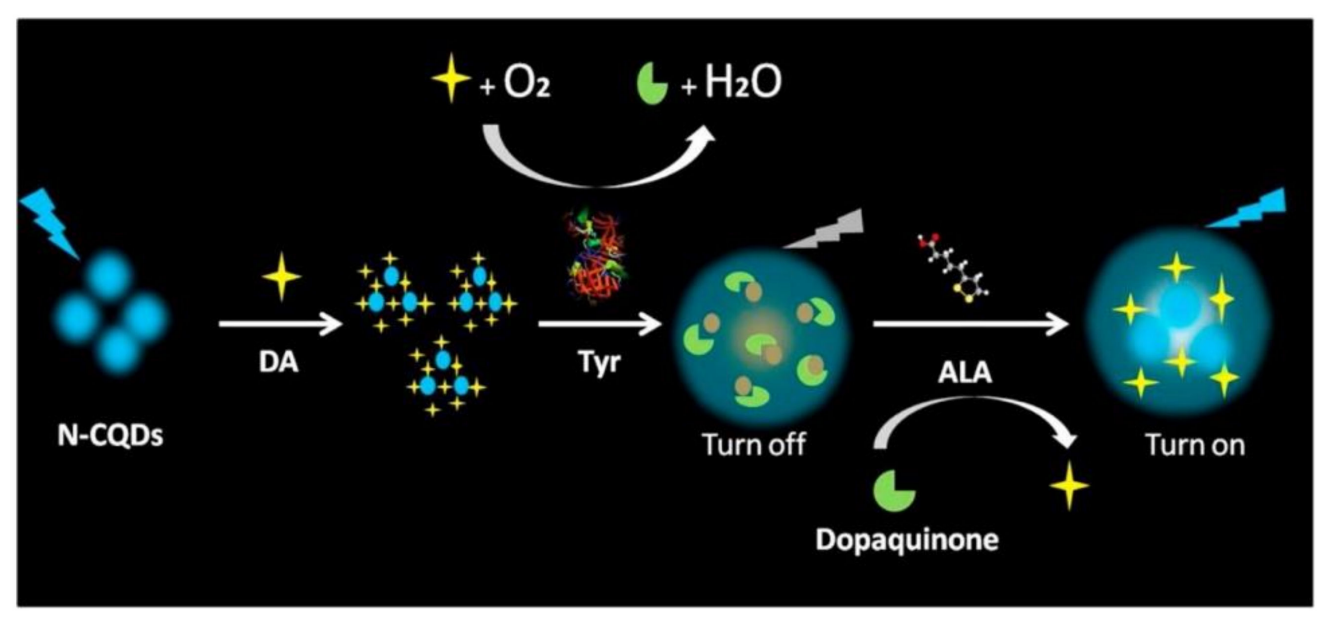

Figure 12. Underlying principle for the sensing of dopamine and alpha lipoic acid. Reprinted from ref. [147], with permission from Elsevier.

Zhang et al. [148] developed the first method resorting to spectroscopy to analyze alpha-lipoic acid (ALA) in real samples. This methodology was also used to determine dopamine (DA). The produced fluorescent nanosensor consisted of nitrogen-doped carbon quantum dots (N-CQDs) and tyrosinase, due to fluorescence emission and effective catalytic oxidation, respectively. The N-CQDs were prepared through hydrothermal synthesis, using anhydrous citric acid and ethylenediamine as starting materials. The as-synthesized $\mathrm{N}$ CQDs displayed excitation independent behavior. The fluorometric assay was based on the quenching of N-CQDs' native fluorescence caused by the addition of DA, and the recovery of said fluorescence by ALA, prompted by inhibition of DA oxidation. The developed "turn OFF-ON" assay for DA and ALA allowed a linear response between 0.05-15 and 0.5-55 $\mu \mathrm{mol} \mathrm{L} \mathrm{L}^{-1}$, with a detection limit of 0.035 and $0.39 \mu \mathrm{mol} \mathrm{L}{ }^{-1}$, correspondently. The quantification of DA and ALA in real samples was performed on human serum and urine samples, with an average recovery of $96-102 \%$ and $99-101 \%$, respectively.

\subsubsection{Ion Sensing}

Yue et al. [149] synthesized ethylenebis(oxyethylenenitrilo)tetraacetic acid (EGTA) modified CQDs via a two-step hydrothermal synthesis to determine intracellular calcium concentration. CQDs synthesis was achieved using citric acid and ethylenediamine as carbon and nitrogen sources, correspondingly. Afterward, the obtained CQDs were modified by the addition of EGTA, followed by a second hydrothermal treatment. A fluorescence platform was developed by correlating the decrease in CQDs fluorescence in the presence of increasing concentrations of calcium, caused by a static fluorescence quenching. This effect was then exploited for the detection of intracellular calcium in HeLa cell cultures, with linearity in the range of $15-300 \mu \mathrm{mol} \mathrm{L}{ }^{-1}$ and a detection limit of $0.38 \mu \mathrm{mol} \mathrm{L}-1$. Moreover, cytotoxicity assays were performed and revealed that CQDs only caused negligible toxicity, as cell viability was $90 \%$ at a concentration of $400 \mu \mathrm{g} \mathrm{mL}^{-1}$. Thus, the prepared CQDs were biocompatible and non-toxic. Singh et al. [150] produced CQDs utilizing mango (Mangifera indica: $M$. indica) leaves as starting material by pyrolysis treatment. The resulting CQDs had a QY of $18.2 \%$ and were applied to $\mathrm{Fe}^{2+}$ ion determination in both water and a Livogen tablet, which was used to validate the efficacy of the methodology, as it is a real sample. The CQDs displayed outstanding binding capability to $\mathrm{Fe}^{2+}$ ions over a wide range of $\mathrm{pH}$ values, most likely due to carboxylic and amine functional groups present in CQDs surface, which caused CQDs fluorescence to suffer quenching. The calculated detection limit was $0.62 \mathrm{ppm}$. Ali et al. [151] developed a CQDs based fluorometric assay for the determination of $\mathrm{Cu}^{2+}$ and $\mathrm{S}^{2-}$ ions in complex matrices. The CQDs were obtained by thermolysis of grape (Vitis vinifera) juice and presented a QY value of 32.1\%. Afterward, CQDs were employed as dual-functional fluorescent probes for quantification of $\mathrm{Cu}^{2+}$ and $\mathrm{S}^{2-}$ ions in environmental water samples, based on the CQDs fluorescence 
quenching when in the presence of $\mathrm{Cu}^{2+}$, which can be caused by their adsorption on the CQDs surface. Upon adding $\mathrm{S}^{2-}$ ions, the fluorescence is recovered due to the stronger interaction between $\mathrm{Cu}^{2+}$ and $\mathrm{S}^{2-}$, which causes the desorption of $\mathrm{Cu}^{2+}$ ions from CQDs surface. The linear range was determined to be $0.07-60 \mu \mathrm{mol} \mathrm{L}^{-1}$ of $\mathrm{Cu}^{2+}$, with a limit of detection and a limit of quantification of 0.02 and $0.066 \mu \mathrm{mol} \mathrm{L}^{-1}$, correspondingly. As for $\mathrm{S}^{2-}$ ion detection, linearity exists in the range of 0.8 to $95 \mu \mathrm{mol} \mathrm{L}^{-1}$ with a limit of detection and a limit of quantification of 0.24 and $0.79 \mu \mathrm{mol} \mathrm{L}^{-1}$, respectively. Sinha et al. [152] fabricated $\mathrm{a} \mathrm{Cr}^{6+}$ and $\mathrm{Fe}^{3+}$ ion sensing nanoprobe using CQDs based on CQDs fluorescence intensity quenching. The CQDs were obtained via hydrothermal synthesis using potatoes and exhibited a QY of $6.08 \%$. The obtained CQDs were then utilized in a simultaneous and selective detection of $\mathrm{Cr}^{6+}$ and $\mathrm{Fe}^{3+}$ ions, even when other cations were present, in river water and tannery water samples. The linear range of the developed methodology was of 0.5-100 and 0.5-5 $\mu \mathrm{mol} \mathrm{L}^{-1}$ for $\mathrm{Cr}^{6+}$ and $\mathrm{Fe}^{3+}$ ions. The detection limit was 0.012 and $0.000549 \mu \mathrm{mol} \mathrm{L}^{-1}$, correspondingly, which represents a concentration value inferior to the one specified by the World Health Organization (WHO).

\subsection{Optoelectronics}

Amongst the distinct optoelectronic applications that CQDs have been employed in, their inclusion in light-emitting diodes (LEDs) and solar cells of solar concentrators has been proving the remarkable adaptability of CQDs to several functions. However, aiming at meeting the requirements for CQDs insertion in photoelectronic devices implies that the water solubility that generally characterizes these nanomaterials must be substituted with affinity for organic solvents. Furthermore, the broad emission with the FWHM exceeding $80 \mathrm{~nm}$ is another feature frequently displayed by CQDs that must be avoided in photoelectronic devices. While metallic semi-conductor QDs usually present these properties more readily than CQDsS, they suffer from optical scintillation and manifest photobleaching, which in long term reduces the efficiency of LEDs [208]. When mentioning solar concentrators, environmental sustainability is a concern that leads to the exploration of the inclusion of "green" materials in those systems. Despite CQDs excellent properties, a limitation to be overcome is the low short-circuit current density (Jsc) presented by CQDs, which restricts the efficiency of the solar cells, comparatively with the open-circuit voltage (Voc) and fill factor (FF) of the metallic semi-conductor QDs, which begin to be commercially available [209].

\subsubsection{Light-Emitting Diodes (LEDs)}

Table 5A summarizes examples of Carbon Quantum Dots used for LEDs. Yuan et al. [166] engineered triangular CQDs with narrow bandwidth emission via solvothermal treatment using three-fold symmetric phloroglucinol (PG) as the reagent (a triangulogen). The triangulogen was selected as a starting material, since it has an exceptional structure, with three extremely reactive hydrogen atoms at the three meta-positions that can be activated by three electron-donating hydroxyl groups, all in a single molecule. To obtain CQDs with narrow bandwidth emission, the triangular form was chosen, since this structure causes the weakening of the electron-phonon coupling and decreases surface defects that seem to be the primary origin of the broadband fluorescence, other than CQDs size polydispersity. After characterization, the as-synthesized CQDs were applied in blue to red LED fabrication, with CQDs imbued in the active emission layer. The LEDs were very stable and displayed high color-purity (FWHM of 30-39 nm), a $\mathrm{L}_{\max }$ of $1882-4762 \mathrm{~cd} \mathrm{~m}^{-2}$, and $\eta_{\mathrm{c}}$ of $1.22-5.11 \mathrm{~cd} \mathrm{~A}^{-1}$. Guner et al. [167] synthesized N-CQDs for white-LED applications. The CQDs were prepared from diammonium hydrogen citrate and urea by reflux method. Then the as-produced CQDs were integrated in a PVPc composite film, originating drop-cast $\mathrm{PVP} / \mathrm{N}-\mathrm{CQDs}$ composite films. Higher concentrations of CQDs in the PVP/N-CQDs composite films generated white-light properties. Since the white light thus produced exhibits red deficiency, commercial inorganic red phosphors were included into PVP/N-CQDs composite films. Additionally, PVP/N-CQDs composite fiber were prepared and used as 
color conversion layers over a blue LED chip. Paulo-Mirasol et al. [168] studied the effect of surface ligands in inverted hybrid light-emitting diodes using CQDs. The CQDs were manufactured through either hydrothermal or hot injection methods. The hydrothermal synthesis of CQDs utilized citric acid, $p$-phenylenediamine (PDA) and ethylenediamine (EDA), or citric acid urea dissolved in dimethylformamide, depending on the desired capping ligand. Hot injection synthesis of CQDs capped by 1-hexadecylamine (HAD) was performed accordingly to a previously reported method [210,211]. It was verified that the usage of capped CQDs enhanced device performance when employed as hole transport layer. The nature of the selected capping ligand has a direct influence on the optoelectronic properties of CQDs, and it was observed that PDA created steric hindrance, which compromised the quality of the interface by inadequately covering the surface of the particle. Additionally, PDA-capped CQDs displayed a lower QY, resulting in devices with poorer current efficiency and luminance. However, employing CQDs capped with EDA generates a low turn-on voltage of $4.90 \mathrm{~V}$, and regardless of the luminance of $70 \mathrm{~cd} / \mathrm{m}^{2}$, CQDs can be used as hole transport materials. In 2020, Zheng et al. [169] fabricated CQDs through a one-step solvothermal method using 2,7-dihydroxynaphthalene and ethylenediamine as the carbon and nitrogen sources, respectively. The CQDs displayed an excellent QY value of $62.98 \%$. 2,7-dihydroxynaphthalen was selected as the carbon source due to its benzenic ring and conjugated structure, which caused an increase in the electronic cloud density, originating CQDs with long-wavelength emission. To fabricate white light emitting diodes (white LEDs), the CQDs solution was dripped onto the inner wall of the optical lens and was dried in the oven at $80^{\circ} \mathrm{C}$ for three hours. Afterward, the optical lens was fixed on the top of the LED chip. The produced white LEDs displayed a correlated color temperature of $2520 \mathrm{~K}$ and a color rendering index of 87 , making them suitable for indoor lighting.

\subsubsection{Solar Energy Conversion}

In Table 5B, examples can be found of Carbon Quantum Dots used for solar converters. Padmanathan et al. [171] developed hybrid carbon dots / titanium dioxide (CQDs/ $\left.\mathrm{TiO}_{2}\right)$ photoelectrodes for application in dye-sensitized photovoltaic solar cells. The CQDs were synthesized via a facile one-step hydrothermal approach utilizing citric acid and urea. Then, $\mathrm{CQDs} / \mathrm{TiO}_{2}$ composites were obtained by mixture of $\mathrm{CQDs}$ with bare $\mathrm{TiO}_{2}$ nanopowder, followed by ultrasonication. The resulting particles size ranged from 30 to $40 \mathrm{~nm}$. CQDs/TiO2 samples displayed higher surface areas $\left(112 \mathrm{~m}^{2} / \mathrm{g}\right)$ and pore size $(30-35 \mathrm{~nm})$ than bare $\mathrm{TiO}_{2}$, which has a direct impact on solar cell efficiency. The photoanode fabricated from CQDs $/ \mathrm{TiO}_{2}$ presented a significative conversion efficiency (PCE) of $15.5 \%$. Zhao et al. [172] have reported the fabrication of luminescent solar concentrators (LSC), as seen in Figure 13, based on the simultaneous utilization of CQDs and mixed-halide inorganic perovskite QDs.
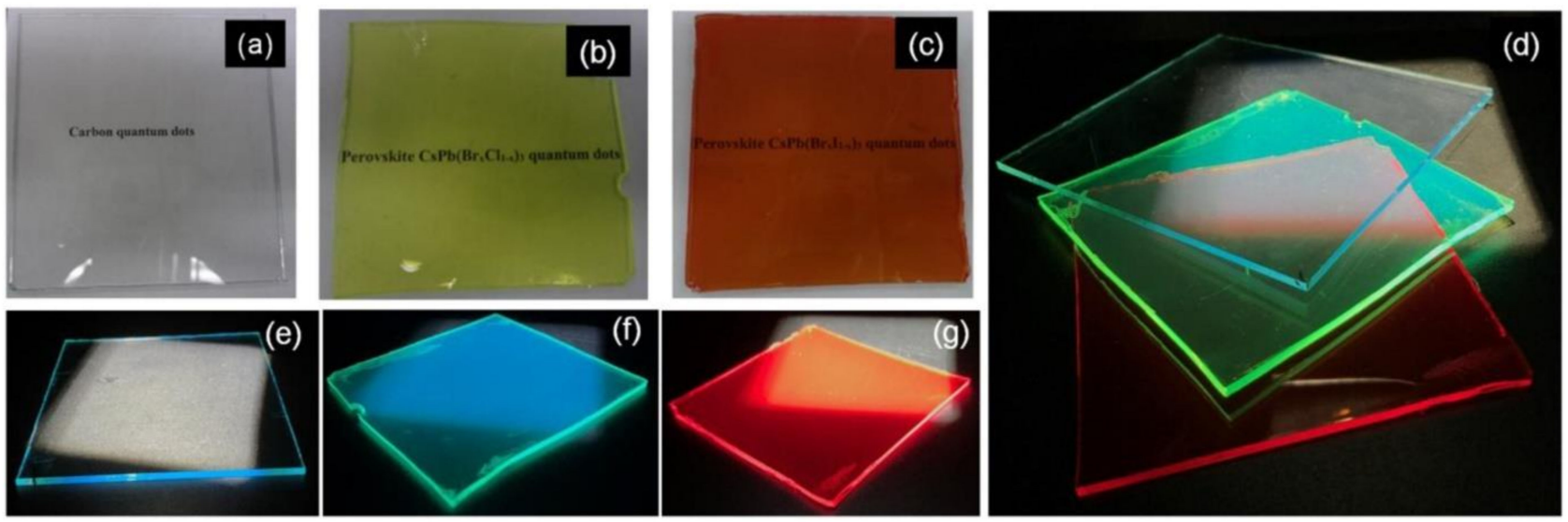

Figure 13. Photographs of the prepared LSC under ambient illumination $(\mathbf{a}-\mathbf{c})$ and one Sun illumination, $100 \mathrm{~mW} / \mathrm{cm}^{2}$ $(\mathbf{d}-\mathbf{g})$. Reprinted from ref. [172], with permission from Elsevier. 
The CQDs were prepared by a hydrothermal synthesis using citric acid and ethylenediamine or citric acid and tris(hydroxymethyl)methyl aminomethane (Tris) as starting materials. The CQDs possessed a large Stokes shift and a QY of $50 \%$. Then, CQDs were combined with polyvinylpyrrolidone (PVP) and spin-coated on a glass substrate. Finally, the semi-transparent tandem LSC based on CQDs and perovskite quantum dots manifested an external optical efficiency of $\sim 3.05 \%$ when submitted to one Sun illumination, signifying a $27 \%$ and $117 \%$ augmentation in efficiency over single layer LSCs manufactured utilizing the same experimental conditions. Wang et al. [173] developed a nanocomposite thin film based on N-CQDs for application in luminescent solar concentrators (LSC). N-CQDs were incorporated in PVP thin films and optical properties and performance of N-CQDs/PVP thin film based LSCs with varying layer numbers and N-CQDs concentrations were ascertained, concluding that when the LSC layer numbers were 7 (0.5 $\mathrm{wt} \% \mathrm{~N}-\mathrm{CQDs})$, the values of $\mathrm{V}_{\mathrm{oc}}, \mathrm{J}_{\mathrm{sc}}, \eta_{\mathrm{opt}}$, and $\eta$ were $0.48 \mathrm{~V}, 19.10 \mathrm{~mA} / \mathrm{cm}^{2}, 5.02 \%$, and $4.97 \%$, correspondingly. Zdražil et al. [212] fabricated a tandem LSC using blue, green, and red CQDs. The CQDs were synthesized via hydrothermal method, and the utilized starting materials were citric acid monohydrate and L-cysteine for blue CQDs; 3,4,9,10-tetranitroperylene powder mixed with $0.2 \mathrm{M} \mathrm{NaOH}$-ethanol mixture for green CQDs; red CQDs were obtained from the conversion of green CQDs after the addition of $1 \mathrm{M} \mathrm{NaOH}$-ethanol solution until the solution turned from green to red. The QY values for the synthesized blue, green, and red CQDs were $63 \%, 78 \%$, and $77 \%$, respectively. The CQDs were then incorporated in tandem LSC, which possessed external optical quantum efficiency of $2.3 \%$ and an elevated degree of transparency, revealing $83.4 \%$ transmittance.

\subsection{Photocatalysis}

Heterogeneous photocatalysis refers to a chemical process in which a solid is responsible for the catalysis of a reaction using ultraviolet, visible, or infrared radiation as an external energy source. Upon photoexcitation, there is a production of electrons and holes that are capable of inducing, correspondingly, either reductive or oxidative reaction routes. Such a process can be exploited for selective organic molecules synthesis, generation of energy vectors, or even the removal of chemical residues or eradication of pathogens in either water or air [213]. CQDs are often employed in photocatalysis processes (Table 6) due to their outstanding capacity for harvesting photons in the visible and UV spectrums and, as photoexcited CQDs, by being exceptional electron acceptors and donors [205].

In 2019, Amadio et al. [180] tested the influence of carbon sources for CQDs in the photocatalytic activity and in structural properties. To do so, six types of CQDs were prepared either by hydrothermal or pyrolytic synthesis, generating, respectively, amorphous (-a) and graphitic (g-) CQDs, using citric acid, glucose, and fructose. It was verified that the easiness of CQDs formation is directly proportional to the reactivity of the carbon precursors towards decomposition/transformation. Thus, g-Fru-CQDs formed a multilayered supramolecular agglomerate of graphene-like crystalline sheets. It was also discovered that citric acid, as a carbon precursor, generated the best performing photoactive nanomaterials, followed by fructose and glucose derived nanomaterials. Moreover, the graphitization of the CQDs carbon core had a direct influence on their photoinduced electron transfer (PET) reactivity, which is fundamental in rational design of carbon-derived nano-photocatalysts. Zhou et al. [114] have induced photocatalytic degradation of both rhodamine B (RhB) and methylene blue (MB) using CQDs synthesized by microwave-assisted method and a mixture of citric acid and 1,2-phenylenediamine as precursors. The prepared CQDs did not show a quantum-size dependent fluorescence mechanism and thus manifested an excitation dependent emission behavior. After purification, three CQDs fraction were isolated and separately employed in the photocatalytic degradation of organic dyes under simulated sunlight irradiation, staying stable for multiple cycles. The interaction between the CQDs and the dyes is depicted in Figure 14. It was found that the photocatalytic activity of CQDs was inversely proportional to CQDs size. CQDs with an average size of $2 \mathrm{~nm}$ were capable of completely degrade both rhodamine $\mathrm{B}(\mathrm{RhB})$ and methylene blue 
(MB) in $150 \mathrm{~min}$. The photocatalytic activity seems to be linked to holes and formation of superoxide radicals. Additionally, the $2 \mathrm{~nm}$ CQDs promoted photocatalytic degradation of p-nitrophenol (PNP).

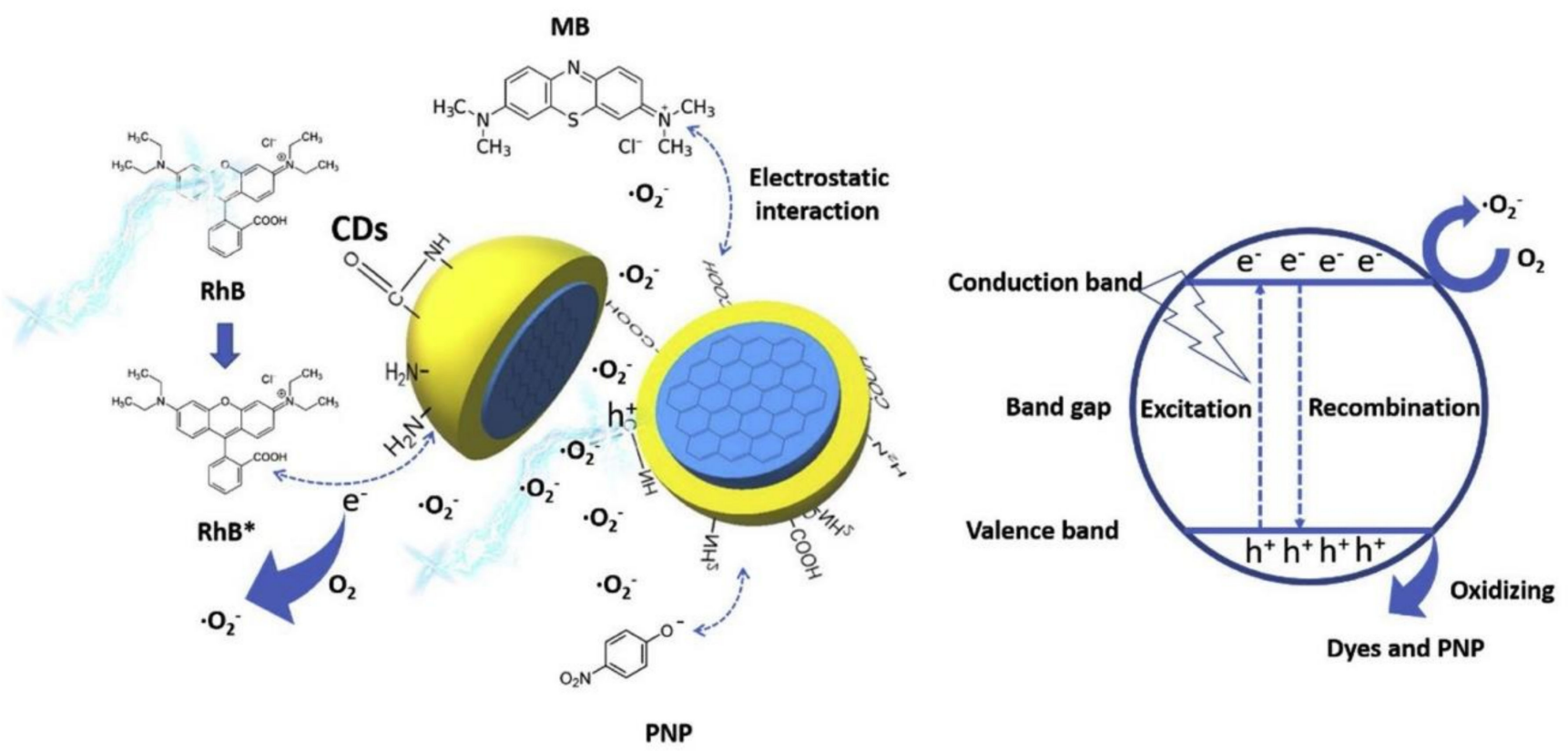

Figure 14. Schematic representation of the interaction between CQDs and dyes during photocatalytic degradation. Reprinted from ref. [114], with permission from Elsevier.

Sabet et al. [178] synthesized N-doped CQDs via a simple hydrothermal, using grass as the starting material. The CQDs were used for the photocatalytic decomposition of six dyes, specifically Acid Blue, Acid Red, Methyl Orange, Eriochrome Black T, Methylene Blue, and Eosin Y, aiming to evaluate CQDs photocatalytic activity. Additionally, due to the high surface area of the N-CQDs, they were employed in $\mathrm{Cd}^{2+}$ and $\mathrm{Pb}^{2+}$ ions removal from water samples, since CQDs can adsorb the mentioned ions on their surfaces. CQDs adsorbed $37 \%$ and $75 \%$ of $\mathrm{Cd}^{2+}$ and $\mathrm{Pb}^{2+}$ ions, respectively. Zhu et al. [179] produced CQDs using waste palm powders as carbon source and thionyl chloride as the dopant, by a one-step hydrothermal method. The CQDs had an average size of $3.54 \mathrm{~nm}$ and an excitation dependent emission behavior. Then, the CQDs were used in the photocatalytic degradation of Rhodamine B and Methylene Blue due to their high photocatalytic activity, which was attributed to the $\mathrm{S}$ and $\mathrm{Cl}$ co-doped structure and small size effect. Under visible light, the Rhodamine B photoinduced degradation was nearly $71.7 \%$, and Methylene Blue was $94.2 \%$ degraded, showing an almost complete degradation of the organic dye.

\subsection{Antimicrobial and Antiviral Activity}

Considering their chemical and optical properties, as well as natural biocompatibility, CQDs display a promising potential for antimicrobial and antiviral applications. CQDs antibacterial properties were found to be mainly dependent on the synthesis process, namely on the morphology and surface functional groups [214]. The presence of amine and amide functional groups on CQDs' surface is known to cause an improvement in antibacterial activity, triggered by the electrostatic interactions established between CQDs and bacterial surfaces. Additionally, the generation of reactive oxygen species after adequate visible light irradiation on the bacterial surface seems to have a part in the antibacterial process. It should be noted that the absence of carboxyl, amino, hydroxyl, or sulfhydryl groups functional groups on CQDs surface is a motive for deficient electrostatic interactions with bacteria, conducing to inefficient antibacterial effects [215]. The same principles can most likely be also applied to other antimicrobial activities such as antifungal or antiparasitic. 
Nowadays, there is not an efficient and specific therapeutical arsenal or vaccines to combat some classes of virus (human or non-human), and since new viral emergencies are expected in the future, the necessity for classical antiviral treatment alternatives is more flagrant than ever. We currently have the coronavirus 2 (SARS-CoV-2) as an example, the strain of coronavirus that caused the coronavirus disease 2019 (COVID-19), responsible for a pandemic that is persisting for months. Additionally, other viral classes may start developing resistance to antiviral agents, reducing their clinical value. As such, investigation has been undertaken in the direction of exploring the antiviral activity of CQDs. CQDs are capable of, for example, inhibiting the binding of virus to host cell receptors [216] or preventing the multiplication of virus [217], which could be valuable when therapeutically options are scarce. Table 7 contains relevant information about some examples of CQDs used as antimicrobials and antivirals.

\subsubsection{Antimicrobial Activity}

Travlou et al. [190] studied the relation between the incorporation of different heteroatoms into CQDs and the bactericidal activity presented by said CQDs. Sulfur and nitrogen-doped carbons quantum dots (S-CQDs and N-CQDs) were manufactured using poly (sodium-4-styrene sulfonate) and polyvinylpyrrolidone, respectively. Afterward, CQDs bactericidal activity was tested against both Gram-negative exemplary species (Escherichia coli, CECT 831) and Gram-positive (Bacillus subtilis subsp. subtilis 168). It was found that N-CQDs presented a greater bactericidal activity comparatively to S-CQDs and that CQDs surface chemistry and sizes had a direct impact on their activity. N-CQDs triggered bacterial death through a mechanism that involved the electrostatic interactions between their protonated forms and the lipids of the bacterial cell membrane and, possibly, by the activation of oxygen species by CQDs surface. Additionally, amides and amines were proven to have an important role in the bactericidal effect enhancement. S-CQDsS presented a size dependent action and contained a negatively charged surface due to dissociation of sulfonic/carboxylic groups and sulfates. Overall, the synthesized CQDs minimum inhibition concentrations were similar or smaller than those of some antibiotics or silver nanoparticles. Song et al. [191] obtained CQDs by pumping cigarette smoke through water, producing a brownish yellow solution of CQDs. Next, the antibacterial activity of the CQDs against Escherichia coli, Staphylococcus aureus, ampicillin-resistant E coli. (AREC), and kanamycin-resistant $E$ coli. (KREC) was evaluated to be within the maximum concentration of $1000 \mu \mathrm{g} \mathrm{mL}^{-1}$. The mechanism for the bactericidal activity presented by CQDs is related to the destruction of double helix structure of DNA and does not cause alterations in the morphology of the bacteria. Additionally, the synthesized CQDs can be broken down into smaller particles and organic fragments in the presence of horseradish peroxidase (HRP) and $\mathrm{H}_{2} \mathrm{O}_{2}$ in seven days and still exhibit efficient antibacterial activity within the first 2-4 days. In addition, four other kinds of CQDs were prepared from camphor tree leaves, mulberry leaves, lalang grass rhizome, and schizonepeta tenuifolia, but were unable to inhibit bacterial growth, proving that starting material selection and consequently, the chemical composition of the synthesized CQDs, can have a prevailing effect upon CQDs' practical application. In 2020, Muktha et al. [131] synthesized CQDs resorting to organic waste of pomegranate and watermelon peels in a microwave-assisted synthesis. The synthesized CQDs antimicrobial activity was tested against the ascomycete fungus Fusarium oxysporum and several bacteria, such as Staphylococcus aureus, Pseudomonas aeruginosa, Bacillus subtilis, and Escherichia coli. It was concluded that CQDs derived from pomegranate peel (P-C dots) have a more significative antimicrobial effect than those synthesized from the watermelon peel (W-C dots). P-C dots have also shown to have a strong antifungal activity when compared to fluconazole, while W-C dots did not manifest any antifungal effect. In addition, both P-C dots and W-C dots have manifested anti-cancer effects against MCF-7 and HepG2 cell lines. Li et al. [192] produced completely degradable and low-toxicity CQDs utilizing vitamin $\mathrm{C}$ as the carbon precursor through a one-step electrochemical synthesis. The CQDs can be totally degraded into $\mathrm{CO}_{2}, \mathrm{CO}$, and $\mathrm{H}_{2} \mathrm{O}$ by irradiation of visible light 
by the action of very mild temperatures (about $37^{\circ} \mathrm{C}$ ) after 20 days. The CQDs were then tested for antibacterial activity against several bacteria, including Staphylococcus aureus, Bacillus subtilis, and Escherichia coli (non-resistant and ampicillin-resistant) and antifungal activity against Rhizoctonia solani and Pyricularia grisea. The best reported bacteriostatic and fungistatic concentrations were 100 and $300 \mu \mathrm{g} \mathrm{mL}^{-1}$, correspondingly. The suggested mechanism of action for CQDs was the entrance in either bacteria or fungus by diffusion, followed by the destruction of the microorganisms wall, binding to bacterial and fungal DNA and RNA and RsNPs gene expression inhibition, which ultimately lead to microbial death at low CQDs concentration.

\subsubsection{Antiviral Activity}

Łoczechin et al. [193] have evaluated the antiviral activity against human coronavirus HCoV229E of seven distinct types of CQDs. Three of the synthesized CQDs caused significant inhibition of HCoV-229E-Luc infection in a concentration-dependent manner, while a fourth type of CQDs manifested only a mild activity against the virus. However, all the seven types of CQDs interfere with the viral replication step. Mechanistic studies indicate that CQDs affect mainly the entry of the virus into the host cell, which could be caused by interference with protein S-receptor interaction with the host cell membrane, as depicted in Figure 15.

\section{Binding of HCoV-229E virus to host cell}

Target cell membrane

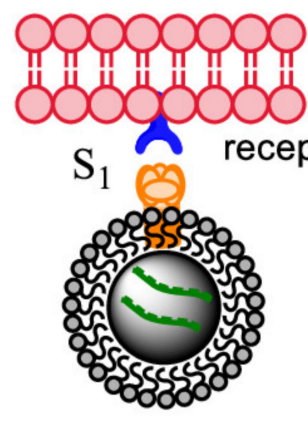

HCoV-229E

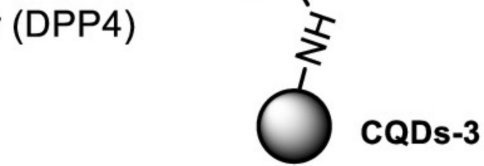

\section{Inhibition of interaction}

(a) Target cell membrane
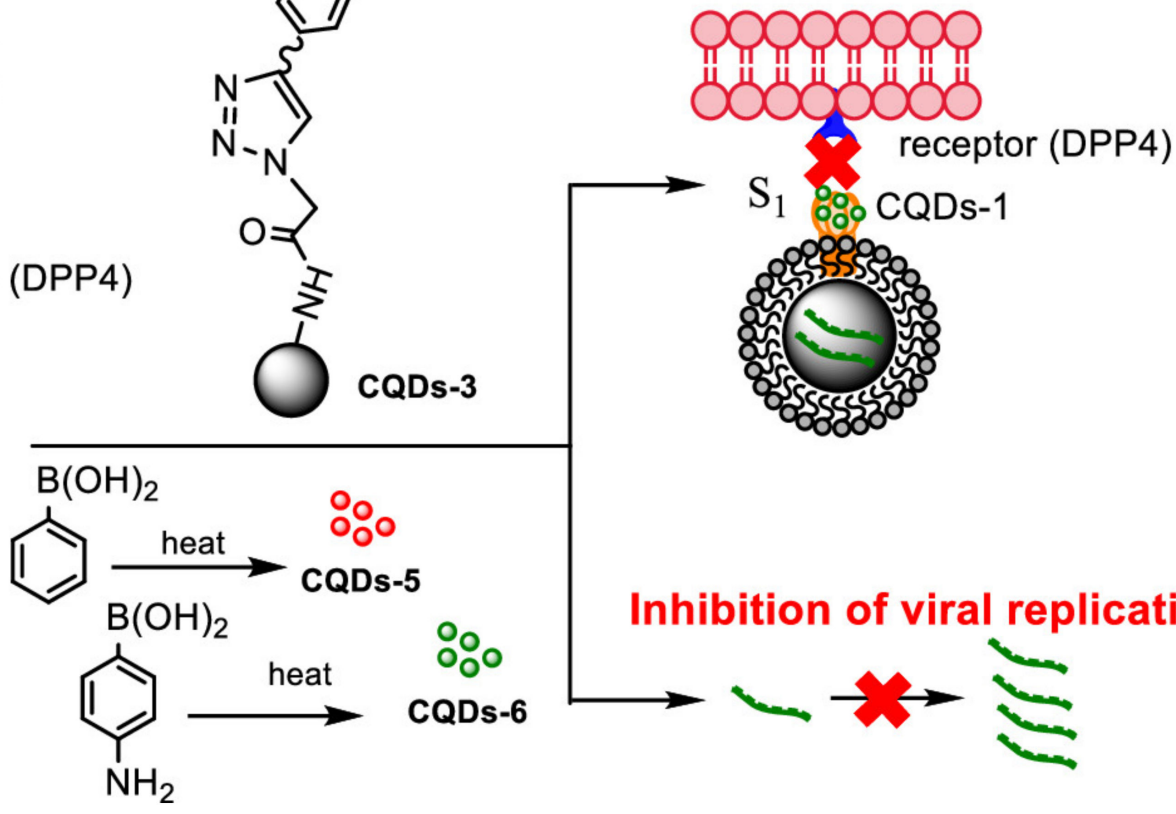

Inhibition of viral replication

Figure 15. Proposed mechanisms for viral replication inhibition of HCoV-229E-Luc infection by CQDs, through the interference with protein $S$ receptor interaction (a) and by the inhibitory influence on the replication of viral RNA genome. Reproduced with permission from ref. [193], published by American Chemical Society, 2019.

In 2019, Huang et al. [194] reported the design of CQDs derived from benzoxazine monomers (BZM-CQDs) and the in vitro evaluation of BZM-CQDs capacity for blockage of multiple viruses' infectivity. The tested viruses were flaviviruses (dengue, Zika, and Japanese encephalitis viruses) and non-enveloped viruses (porcine parvovirus- and adenovirus-associated virus). It was discovered that BZM-CQDs were capable of direct interaction with virions and, consequently, caused the inhibition of virion entrance into the host cell. Due to this mechanism, it was concluded that BZM-CQDs might provide a broad-spectrum therapeutic possibility against phylogenetically related and unrelated 
viruses. Tong et al. [195] synthesized glycyrrhizic acid derived CQDs (Gly-CQDs) from the medicinal Chinese plant Glycyrrhiza uralensis employing the hydrothermal method. Said Gly-CQDs were later determined to possess an excellent antiviral activity $(\approx 5$ orders of magnitude) against porcine reproductive and respiratory syndrome (PRRSV). Additionally, mechanistic studies revealed the antiviral mechanism of Gly-CQDs to be based on the inhibition of PRRSV invasion and replication in vitro, inactivation of PRRSV, blockage of ROS production induced by PRRSV infection, and stimulation of host immune cells to increase interferon production. Proteomics studies suggested that Gly-CQDs are responsible for the upregulation of intracellular antiviral proteins and downregulation of pro-viral proteins. Huang et al. [196] evaluated the antiviral activity of polyamine-modified CQDs (polyamine CQDs) against white spot syndrome virus (WSSV), responsible for the white spot syndrome (WSS), which is a common cause of death of cultured shrimp. Polyamine CQDs could bind to the WSSV envelope, inhibiting the viral infection in a dose-dependent manner. Moreover, polyamine CQDs generated an upregulation of various immune genes in shrimp, including antimicrobial immune responses, hemolymph clotting mechanism, antioxidant defense mechanism, and antimicrobial peptide system, although the immune gene expression was not directly proportional to the dosage administered. Polyamine CQDs also caused a decrease in shrimp mortality upon WSSV infection.

\section{Pharmacokinetics, Pharmacodynamics, and Toxicity}

Despite the well-known water solubility and biocompatibility displayed by CQDs, their application on the clinical scenario depends on investigating possible toxicity pathways and meticulously study their pharmacokinetics. All implanted biomaterials have the potential to trigger immunological responses, such as foreign body responses (FBRs), known to cause an inefficient activity of CQDs [218]. They may also trigger unwanted biological interactions, such as bio-coronation by proteins, lipids, or other macromolecules. Furthermore, the possibility of enzymatic degradation by immune-competent cells should not be ignored, as it can compromise CQDs biological activity. Furthermore, with the intention of employing CQDs as therapeutic agents, a detailed exploration of their pharmacokinetic profiling concerning adsorption, distribution, metabolism, and excretion (ADME) must be undertaken. Finally, the role of metabolic activity on CQDs action in vivo is of outmost importance, as both bioactivation and biodegradation can lead to unwarranted effects [219].

In 2019, Singh et al. [220] systematically evaluated the in vivo and in vitro toxicity of N-CQDs. For the first time, an extensive assessment of the phenomena of in vitro cytoand genotoxicity of CQDs was entailed, and an in-depth analysis of hematological, biochemical, and histopathological parameters in vivo was performed in Swiss albino mice. The N-CQDs utilized for the study were synthesized from D-glucose and ethylenediamine that, after neutralization with acetic acid, were submitted to microwave irradiation. The as-prepared N-CQDs manifested an excitation dependent emission behavior and an average size of $\sim 3.7 \mathrm{~nm}$. The N-CQDs also possessed a highly hydrophilic nature. The in vivo toxicological effect monitoring was carried out for up to 30 days, at two distinct N-CQDs concentration, namely $5.0 \mathrm{mg}$ per $\mathrm{kg}$ body weight $(\mathrm{BW})$ and $10.0 \mathrm{mg}$ per $\mathrm{kg} \mathrm{BW}$. No acute morphological and toxicity changes were verified, and results of hematological, serum biochemical, antioxidant, and histopathological parameters did not imply significative $\mathrm{N}-\mathrm{CQDs}$ toxicity. Furthermore, the liver, kidney, and spleen remained without observable inflammation or disruption at the 30th day after the administration of the N-CQDs. Finally, the in vitro assay was executed against HeLa cells, using N-CQDs in the concentration range of $0-400 \mu \mathrm{g} \mathrm{mL}{ }^{-1}$. The growth cycle of cells, lactate dehydrogenase (LDH) profile, apoptosis, and DNA fragmentation corroborated the in vivo results. Thus, N-CQDs were deemed nontoxic via intravenous application route and up to the tested concentration of $400 \mu \mathrm{g} \mathrm{mL}{ }^{-1}$. Liang et al. [221] have prepared three different types of nitrogen- and sulfurdoped CQDs (N,S-CQDs) to study their interaction with human serum albumin (HSA). The three kinds of CQDs were produced either using citric acid (CA), glucose, or ascorbic acid 
(AA) as distinct carbon sources, and the combination of urea and N-Acetyl-L-cysteine as nitrogen and sulfur dopants via hydrothermal method. The CQDs were named according to their carbon source, specifically CQDs (CA) for citric acid, CQDs (glucose) for glucose, and CQDs (AA) for ascorbic acid. Upon characterization, CQDs (glucose) and CQDs (AA) manifested excitation dependent emission behavior, while CQDs' (CA) fluorescence was excitation independent. Additionally, all CQDs displayed a $\mathrm{pH}$-dependent fluorescence and were highly stable under different ionic strengths and prolonged light exposure. However, CQDs fluorescence decreased upon the increase of temperature, revealing a weak thermostability. Concerning CQDs interaction with HSA, it was concluded that the different types of CQDs showed distinct quenching mechanisms on the intrinsic fluorescence of HSA. While both CQDs (glucose) and CQDs (CA) caused a decrease in HSA fluorescence by dynamic quenching, the interaction between CQDs (AA) caused static quenching. Considering CQDs (AA) quenching mechanism, site-selective binding with HSA was studied by using Warfarin, which binds to the site I of serum albumin, and ibuprofen, which binds to site II of serum albumin. The assay revealed that the CDs (AA) were mainly present in site I of HAS, leading to conclude that CQDs (AA) preferably interacted with site I of HSA, which is also the binding site for Warfarin. Finally, it was concluded that all CQDs could induce conformational changes in HSA. Yan et al. [222] have evaluated the intracellular uptake of two differently functionalized CQDs at three cell cycle phases (G0/G1, S and G2/M) using HeLa cells, as well as different internalization pathways and translocations. The CQDs were obtained by functionalization of CQDs synthesized from commercially acquired carbon nanopowders. EPA-CQDs and PEI-CQDs were produced functionalizing CQDs with 3-ethoxypropylamine and polyethylenimine, respectively. Concerning internalization pathways, a slightly higher internalization efficiency for PEI-CQDs was verified, and the presence of serum could effectively enhance cellular uptake of EPA-CQDs, while significantly inhibiting that of PEI-CQDs. The study of the effect of cell cycle phase on CQDs uptake revealed that when serum was present, the main uptake pathway of EPA-CQDs was clathrin-mediated endocytosis [223]. Additionally, caveolae-mediated endocytosis [224] was observed, particularly in cells at the S phase. In cells at the G1/G0 phase, there was also micropinocytosis. In serum-free media, EPA-CQDs suffered uptake mainly through clathrin-mediated endocytosis. As for PEI-CQDs, in serum-containing media, caveolae-mediated endocytosis and micropinocytosis were accountable for the some of the verified uptake, implying the involvement of other internalization pathways. In serum-free media, the uptake of PEI-CQDs was caused by the contribution of clathrinmediated endocytosis, micropinocytosis, and caveolin-mediated endocytosis, in cells at $S$ phase. In cells at G0/G1 phase, the uptake was triggered by clathrin-mediated endocytosis, with minor contribution by caveolae-mediated endocytosis, whereas in cells at G2/M, the only pathway involved was caveolae-mediated endocytosis, with a very small contribution, leading to the conclusion that the internalization of PEI-CQDs by the HeLa cells is strongly affected by cellular cycle. As for the intracellular localization of CQDs, it was found that while the lysosome was the only destination for EPA-CQDs, PEI-CQDs were initially found on both lysosome and mitochondria and then moved out of mitochondria, remaining in the lysosomes. Figure 16 illustrates the differences in the intracellular uptake of EPA-CDots and PEI-CDots. 

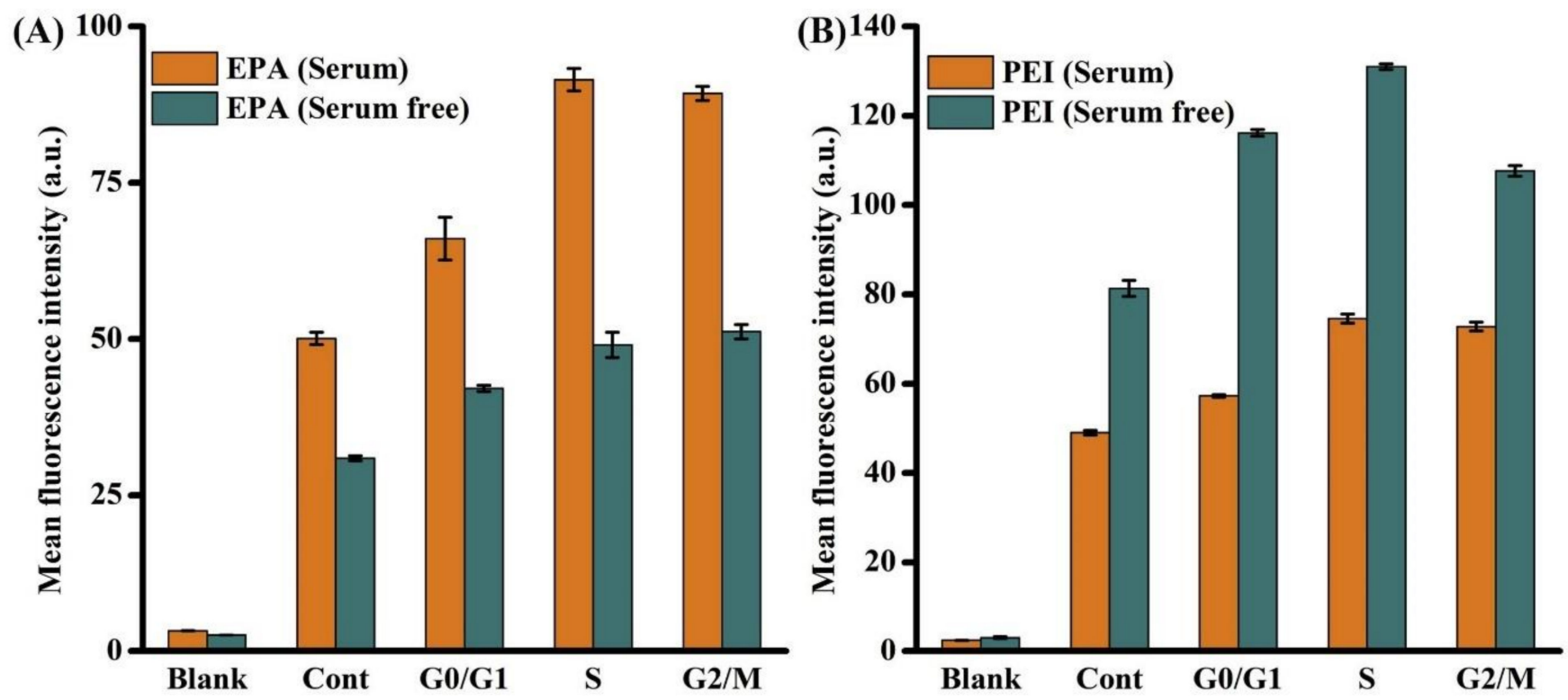

Figure 16. Intracellular uptake of EPA-CQDs (A) and PEI-CQDs (B) by normal HeLa cells (Cont) and by cells at three cell cycle phases (G0/G1, S, and G2/M), cultured in media with and without serum. Reprinted from ref. [222], with permission from Elsevier.

In 2019, Srivastava et al. [225] described CQDs degradation kinetics after subjection to enzymatic oxidation, in an attempt at clarifying the metabolic fate of these nanosystems in a biological environment. CQDs were firstly manufactured via hydrothermal method using sucrose as the carbon source and polyethylene glycol (PEG), phospholipids, and polyethylene glycol phosphate, for the formation of CQDs-PEG, CQDs-lipid, and CQDs- $\mathrm{PO}_{4}$, respectively. Additionally, CQDs-PEI were obtained by functionalization with polyethyleneimine (PEI). Therefore, the passivation agent was responsible for the surface charge of CQDs, allowing the design of neutral, zwitterionic, positive, and negative CQDs corresponding to CQDs-PEG, CQDs-lipid, CQDs-PO ${ }_{4}$, and CQDs-PEI. Then, the as-prepared CQDs were submitted to peroxide catalyzed degradation in the presence of porcine lipase, which showed that not only the surface charge of CQDs promoted distinct degradation kinetics upon enzymatic oxidation, but also that their decomposition correlates with CQDs accessibility to porcine lipase. It was found that CQDs-PEG were the first CQDs to be degraded, followed by CQDs-PO ${ }_{4}$ and CQDs-PEI. The last CQDs to be degraded were CQDs-lipid, possibly due to the initial degradation of lipid molecules, which delayed the degradation of CQDs-lipid. Regarding the formed metabolites, hydroxymethylfurfural was a common metabolite produced after the degradation of all CQDs.

\section{Conclusions and Future Perspective}

Considering CQDs' unique and versatile properties, it is not surprising that they have been extensively explored in diverse applications, resulting in an accentuated growth of the scientific publications related to the field of CQDs research in recent years. Amongst other useful properties, CQDs are known to possess low cytotoxicity, photochemical stability, and easily modified surface, which not only makes them formidable alternatives to metalbased semiconductor QDs, but also could revolutionize our understanding of several fields, especially biomedicine. The chemical and physical characteristics of CQDs that make them ideal for such a vast number of scientific thematic and fields of applications are mainly imparted during their synthesis. The innovation that has been experienced in CQDs synthesis, from intricate methods to greener synthesis using common sustainable organic materials, is partially responsible for the attention this kind of nanomaterial has garnered. Green synthesis of CQDs is a strategy that has allowed the production of CQDs without the need for environmental aggressive chemicals or substantial energy consumption due to 
high experimental temperatures, ensuing in a decrease in production cost and promoting the implementation of sustainable development in CQDs research field.

Nevertheless, despite the considerable collective work that has been entailed on the synthesis, purification or separation, application, and investigation of fluorescence mechanism, there is still much to be elucidated. Regarding CQDs synthesis, contemporary challenges present themselves in the lack of fine control of size, crystallinity, and morphology of CQDs, which is exposed by the shortage of clear-cut synthesis protocols for the manufacturing of well-defined chemical identities. Additionally, considering that intrinsic structure and surface components of CQDs have a direct impact on their fluorescence, low QY and non-uniform optical properties are not uncommon amongst this new nanomaterial, although some examples prove that this challenge can be overcome. Other than the difficulty in having a precise manipulation of CQDs properties and characteristics, the fact that the fluorescence mechanism of CQDs is yet to be established is another reason that could be responsible for low QY and related phenomena. Until the origin of CQDs fluorescence is documented and understood, the deficiency of intensive brightness could prove to be an obstacle to some applications, particularly bioimaging, in which high QY is crucial. To transport the experimental data to clinical reality, besides surmounting the previously mentioned challenges, the study of pharmacokinetics and biodistribution of CQDs must be profoundly ensued, as well as the multifaceted interaction between CQDs and biological environments. For that end, the interaction between CQDs and proteins, cells, or various types of tissues must be investigated.

Notwithstanding, tackling and vanquishing the present challenges and obstacles that are intertwined with the evolution of CQDs science will have a critical impact on the field. The uniqueness displayed by CQDs, even though much knowledge needs to be learned, is the driving force that will propel chemists, biologists, engineers, material scientists, and clinicians to find brand new ways to synthesize, understand, modify, and apply these nanomaterials that are singular in their biocompatibility, optical properties, as well as chemical and physical stability. Soon, should the clinical use of CQDs become a reality, the benefit for patients in diverse clinical situations and society in general will be, undoubtedly, palpable. At the dawn of a new decade, the possibilities for this new nanomaterial are almost limitless, and when the hindrances that block some of the CQDs potential have been scrutinized and further investigated, the CQDs research field will be bound to flourish.

Author Contributions: Conceptualization: H.B.A.S. and J.A.V.P.; methodology: H.B.A.S. and J.A.V.P.; formal analysis: C.S.M.M. and J.A.V.P.; investigation: H.B.A.S. and C.S.M.M.; writing-original draft preparation: H.B.A.S. and C.S.M.M.; writing-review and editing: H.B.A.S., C.S.M.M., and J.A.V.P.; supervision: J.A.V.P.; project administration: J.A.V.P. funding acquisition: J.A.V.P. Authorship must be limited to those who have contributed substantially to the work reported. All authors have read and agreed to the published version of the manuscript.

Funding: This work received financial support from National Funds (FCT, Fundação para a Ciência e Tecnologia) through project PTDC/MED-QUI/29800/2017.

Institutional Review Board Statement: Not applicable.

Informed Consent Statement: Not applicable.

Data Availability Statement: Not applicable.

Acknowledgments: We gratefully acknowledge the support of LAQV-REQUIMTE (UIDB/50006/2020 and UIDP/50006/2020).

Conflicts of Interest: There are no conflicts of interest to declare. 


\section{References}

1. Boakye-Yiadom, K.O.; Kesse, S.; Opoku-Damoah, Y.; Filli, M.S.; Aquib, M.; Joelle, M.M.B.; Farooq, M.A.; Mavlyanova, R.; Raza, F.; Bavi, R.; et al. Carbon dots: Applications in bioimaging and theranostics. Int. J. Pharm. 2019, 564, 308-317. [CrossRef] [PubMed]

2. Singh, R.K.; Kumar, R.; Singh, D.P.; Savu, R.; Moshkalev, S.A. Progress in microwave-assisted synthesis of quantum dots (graphene/carbon/semiconducting) for bioapplications: A review. Mater. Today Chem. 2019, 12, 282-314. [CrossRef]

3. Cayuela, A.; Soriano, M.L.; Carrillo-Carrion, C.; Valcarcel, M. Semiconductor and carbon-based fluorescent nanodots: The need for consistency. Chem. Commun. 2016, 52, 1311-1326. [CrossRef]

4. Xu, X.; Ray, R.; Gu, Y.; Ploehn, H.J.; Gearheart, L.; Raker, K.; Scrivens, W.A. Electrophoretic analysis and purification of fluorescent single-walled carbon nanotube fragments. J. Am. Chem. Soc. 2004, 126, 12736-12737. [CrossRef] [PubMed]

5. Molaei, M.J. A review on nanostructured carbon quantum dots and their applications in biotechnology, sensors, and chemiluminescence. Talanta 2019, 196, 456-478. [CrossRef] [PubMed]

6. Yuan, F.; Li, S.; Fan, Z.; Meng, X.; Fan, L.; Yang, S. Shining carbon dots: Synthesis and biomedical and optoelectronic applications. Nano Today 2016, 11, 565-586. [CrossRef]

7. Yan, F.; Sun, Z.; Zhang, H.; Sun, X.; Jiang, Y.; Bai, Z. The fluorescence mechanism of carbon dots, and methods for tuning their emission color: A review. Mikrochim. Acta 2019, 186, 583. [CrossRef]

8. Wu, Y.F.; Wu, H.C.; Kuan, C.H.; Lin, C.J.; Wang, L.W.; Chang, C.W.; Wang, T.W. Multi-functionalized carbon dots as theranostic nanoagent for gene delivery in lung cancer therapy. Sci. Rep. 2016, 6, 21170. [CrossRef]

9. Wang, W.; Damm, C.; Walter, J.; Nacken, T.; Peukert, W. Photobleaching and stabilization of carbon nanodots produced by solvothermal synthesis. Phys. Chem. Chem. Phys. 2015, 18. [CrossRef]

10. Sun, Y.-P.; Zhou, B.; Lin, Y.; Wang, W.; Fernando, K.A.S.; Pathak, P.; Meziani, M.J.; Harruff, B.A.; Wang, X.; Wang, H.; et al. Quantum-Sized Carbon Dots for Bright and Colorful Photoluminescence. J. Am. Chem. Soc. 2006, 128, 7756-7757. [CrossRef]

11. Devi, P.; Saini, S.; Kim, K.H. The advanced role of carbon quantum dots in nanomedical applications. Biosens. Bioelectron. 2019, 141, 111158. [CrossRef] [PubMed]

12. Chan, K.K.; Yap, S.H.K.; Yong, K.T. Biogreen Synthesis of Carbon Dots for Biotechnology and Nanomedicine Applications. Nanomicro Lett. 2018, 10, 72. [CrossRef]

13. Liu, M.L.; Chen, B.B.; Li, C.M.; Huang, C.Z. Carbon dots: Synthesis, formation mechanism, fluorescence origin and sensing applications. Green Chem. 2019, 21, 449-471. [CrossRef]

14. Hassan, M.; Gomes, V.G.; Dehghani, A.; Ardekani, S.M. Engineering carbon quantum dots for photomediated theranostics. Nano Res. 2017, 11, 1-41. [CrossRef]

15. Li, L.; Dong, T. Photoluminescence tuning in carbon dots: Surface passivation or/and functionalization, heteroatom doping. J. Mater. Chem. C 2018, 6, 7944-7970. [CrossRef]

16. Das, R.; Bandyopadhyay, R.; Pramanik, P. Carbon quantum dots from natural resource: A review. Mater. Today Chem. 2018, 8 , 96-109. [CrossRef]

17. Iravani, S.; Varma, R. Green synthesis, biomedical and biotechnological applications of carbon and graphene quantum dots. A review. Environ. Chem. Lett. 2020, 18, 10-1007. [CrossRef]

18. Xu, Q.; Kuang, T.; Liu, Y.; Cai, L.; Peng, X.; Sreenivasan Sreeprasad, T.; Zhao, P.; Yu, Z.; Li, N. Heteroatom-doped carbon dots: Synthesis, characterization, properties, photoluminescence mechanism and biological applications. J. Mater. Chem. B 2016, 4, 7204-7219. [CrossRef]

19. Anwar, S.; Ding, H.; Xu, M.; Hu, X.; Li, Z.; Wang, J.; Liu, L.; Jiang, L.; Wang, D.; Dong, C.; et al. Recent Advances in Synthesis, Optical Properties, and Biomedical Applications of Carbon Dots. ACS Appl. Bio Mater. 2019, 2, 2317-2338. [CrossRef]

20. Namdari, P.; Negahdari, B.; Eatemadi, A. Synthesis, properties and biomedical applications of carbon-based quantum dots: An updated review. Biomed. Pharmacother. 2017, 87, 209-222. [CrossRef]

21. Wang, X.; Feng, Y.; Dong, P.; Huang, J. A Mini Review on Carbon Quantum Dots: Preparation, Properties, and Electrocatalytic Application. Front. Chem. 2019, 7, 671. [CrossRef]

22. Baragau, I.-A.; Power, N.P.; Morgan, D.J.; Heil, T.; Lobo, R.A.; Roberts, C.S.; Titirici, M.-M.; Dunn, S.; Kellici, S. Continuous hydrothermal flow synthesis of blue-luminescent, excitation-independent nitrogen-doped carbon quantum dots as nanosensors. J. Mater. Chem. A 2020, 8, 3270-3279. [CrossRef]

23. Gawande, M.B.; Shelke, S.N.; Zboril, R.; Varma, R.S. Microwave-assisted chemistry: Synthetic applications for rapid assembly of nanomaterials and organics. Acc. Chem. Res. 2014, 47, 1338-1348. [CrossRef] [PubMed]

24. Li, H.; Xu, Y.; Ding, J.; Zhao, L.; Zhou, T.; Ding, H.; Chen, Y.; Ding, L. Microwave-assisted synthesis of highly luminescent N-and S-co-doped carbon dots as a ratiometric fluorescent probe for levofloxacin. Mikrochim. Acta 2018, 185, 104. [CrossRef]

25. Das, A.; Snee, P.T. Synthetic Developments of Nontoxic Quantum Dots. ChemPhysChem 2016, 17, 598-617. [CrossRef]

26. Leong, C.R.; Tong, W.Y.; Tan, W.-N.; Tumin, N.D.; Yusof, F.A.M.; Yacob, L.S.; Rosli, M.I.H.B.; Md Abu, T. Synthesis of curcumin quantum dots and their antimicrobial activity on necrotizing fasciitis causing bacteria. Mater. Today Proc. 2020, $31,31-35$. [CrossRef]

27. Reyes, D.; Camacho, M.; Camacho, M.; Mayorga, M.; Weathers, D.; Salamo, G.; Wang, Z.; Neogi, A. Laser Ablated Carbon Nanodots for Light Emission. Nanoscale Res. Lett. 2016, 11, 424. [CrossRef] [PubMed]

28. Nguyen, V.; Zhao, N.; Yan, L.; Zhong, P.; Nguyen, V.C.; Le, P.H. Double-pulse femtosecond laser ablation for synthesis of ultrasmall carbon nanodots. Mater. Res. Express 2020, 7, 015606. [CrossRef] 
29. Gan, Y.X.; Jayatissa, A.H.; Yu, Z.; Chen, X.; Li, M. Hydrothermal Synthesis of Nanomaterials. J. Nanomater. 2020, 2020,1 -3. [CrossRef]

30. Xue, B.; Yang, Y.; Sun, Y.; Fan, J.; Li, X.; Zhang, Z. Photoluminescent lignin hybridized carbon quantum dots composites for bioimaging applications. Int. J. Biol. Macromol. 2019, 122, 954-961. [CrossRef]

31. Qian, J.; Quan, F.; Zhao, F.; Wu, C.; Wang, Z.; Zhou, L. Aconitic acid derived carbon dots: Conjugated interaction for the detection of folic acid and fluorescence targeted imaging of folate receptor overexpressed cancer cells. Sens. Actuators B Chem. 2018, 262, 444-451. [CrossRef]

32. Zhang, M.; Hu, L.; Wang, H.; Song, Y.; Liu, Y.; Li, H.; Shao, M.; Huang, H.; Kang, Z. One-step hydrothermal synthesis of chiral carbon dots and their effects on mung bean plant growth. Nanoscale 2018, 10, 12734-12742. [CrossRef]

33. Prathumsuwan, T.; Jamnongsong, S.; Sampattavanich, S.; Paoprasert, P. Preparation of carbon dots from succinic acid and glycerol as ferrous ion and hydrogen peroxide dual-mode sensors and for cell imaging. Opt. Mater. 2018, 86, 517-529. [CrossRef]

34. Khan, Z.M.S.H.; Saifi, S.; Shumaila Aslam, Z.; Khan, S.A.; Zulfequar, M. A facile one step hydrothermal synthesis of carbon quantum dots for label-free fluorescence sensing approach to detect picric acid in aqueous solution. J. Photochem. Photobiol. A Chem. 2020, 388, 112201. [CrossRef]

35. Sun, J.; Wang, W.; Yue, Q. Review on Microwave-Matter Interaction Fundamentals and Efficient Microwave-Associated Heating Strategies. Materials 2016, 9, 231. [CrossRef]

36. Uriarte, D.; Domini, C.; Garrido, M. New carbon dots based on glycerol and urea and its application in the determination of tetracycline in urine samples. Talanta 2019, 201, 143-148. [CrossRef] [PubMed]

37. Lu, S.; Liu, L.; Wang, H.; Zhao, W.; Li, Z.; Qu, Z.; Li, J.; Sun, T.; Wang, T.; Sui, G. Synthesis of dual functional gallic-acid-based carbon dots for bioimaging and antitumor therapy. Biomater. Sci. 2019, 7, 3258-3265. [CrossRef] [PubMed]

38. Hinterberger, V.; Wang, W.; Damm, C.; Wawra, S.; Thoma, M.; Peukert, W. Microwave-assisted one-step synthesis of white light-emitting carbon dot suspensions. Opt. Mater. 2018, 80, 110-119. [CrossRef]

39. Seifikar, F.; Azizian, S.; Sillanpää, M. Microwave-assisted synthesis of carbon powder for rapid dye removal. Mater. Chem. Phys. 2020, 250, 123057. [CrossRef]

40. Li, D.; Li, W.; Zhang, H.; Zhang, X.; Zhuang, J.; Liu, Y.; Hu, C.; Lei, B. Far-Red Carbon Dots as Efficient Light-Harvesting Agents for Enhanced Photosynthesis. ACS Appl. Mater. Interfaces 2020, 12, 21009-21019. [CrossRef]

41. Farshbaf, M.; Davaran, S.; Rahimi, F.; Annabi, N.; Salehi, R.; Akbarzadeh, A. Carbon quantum dots: Recent progresses on synthesis, surface modification and applications. Artif. Cells Nanomed. Biotechnol. 2018, 46, 1331-1348. [CrossRef] [PubMed]

42. Niu, F.; Ying, Y.-L.; Hua, X.; Niu, Y.; Xu, Y.; Long, Y.-T. Electrochemically generated green-fluorescent N-doped carbon quantum dots for facile monitoring alkaline phosphatase activity based on the Fe3+-mediating ON-OFF-ON-OFF fluorescence principle. Carbon 2018, 127, 340-348. [CrossRef]

43. Huang, S.; Yao, J.; Chu, X.; Ning, G.; Zhou, Z.; Liu, Y.; Xiao, Q. A ratiometric fluorescent assay for evaluation of alkaline phosphatase activity based on ionic liquid-functionalized carbon dots. Mikrochim. Acta 2020, 187, 271. [CrossRef]

44. Kumar, R.; Kumar, V.B.; Gedanken, A. Sonochemical synthesis of carbon dots, mechanism, effect of parameters, and catalytic, energy, biomedical and tissue engineering applications. Ultrason. Sonochem. 2020, 64, 105009. [CrossRef]

45. He, C.; Yan, H.; Li, X.; Wang, X. In situ fabrication of carbon dots-based lubricants using a facile ultrasonic approach. Green Chem. 2019, 21, 2279-2285. [CrossRef]

46. Lu, M.; Zhou, L. One-step sonochemical synthesis of versatile nitrogen-doped carbon quantum dots for sensitive detection of Fe (2+) ions and temperature in vitro. Mater. Sci. Eng. C 2019, 101, 352-359. [CrossRef] [PubMed]

47. Amans, D.; Diouf, M.; Lam, J.; Ledoux, G.; Dujardin, C. Origin of the nano-carbon allotropes in pulsed laser ablation in liquids synthesis. J. Colloid Interface Sci. 2017, 489, 114-125. [CrossRef]

48. Isnaeni, I.; Suliyanti, M.M.; Shiddiq, M.; Sambudi, N.S. Optical Properties of Toluene-soluble Carbon Dots Prepared from Laser-ablated Coconut Fiber. Makara J. Sci. 2019, 23, 187-192. [CrossRef]

49. Tejwan, N.; Saha, S.K.; Das, J. Multifaceted applications of green carbon dots synthesized from renewable sources. Adv. Colloid Interface Sci. 2020, 275, 102046. [CrossRef]

50. Ren, X.; Zhang, F.; Guo, B.; Gao, N.; Zhang, X. Synthesis of N-Doped Micropore Carbon Quantum Dots with High Quantum Yield and Dual-Wavelength Photoluminescence Emission from Biomass for Cellular Imaging. Nanomaterials 2019, 9, 495. [CrossRef]

51. Devi, P.; Thakur, A.; Bhardwaj, S.K.; Saini, S.; Rajput, P.; Kumar, P. Metal ion sensing and light activated antimicrobial activity of aloe-vera derived carbon dots. J. Mater. Sci. Mater. Electron. 2018, 29, 17254-17261. [CrossRef]

52. Bhamore, J.R.; Jha, S.; Park, T.J.; Kailasa, S.K. Green synthesis of multi-color emissive carbon dots from Manilkara zapota fruits for bioimaging of bacterial and fungal cells. J. Photochem. Photobiol. B 2019, 191, 150-155. [CrossRef] [PubMed]

53. Chen, B.B.; Liu, M.L.; Li, C.M.; Huang, C.Z. Fluorescent carbon dots functionalization. Adv. Colloid Interface Sci. 2019, 270, 165-190. [CrossRef]

54. Lu, W.; Gong, X.; Nan, M.; Liu, Y.; Shuang, S.; Dong, C. Comparative study for N and S doped carbon dots: Synthesis, characterization and applications for $\mathrm{Fe}(3+)$ probe and cellular imaging. Anal. Chim. Acta 2015, 898, 116-127. [CrossRef] [PubMed]

55. Xu, Q.; Liu, Y.; Gao, C.; Wei, J.; Zhou, H.; Chen, Y.; Dong, C.; Sreeprasad, T.S.; Li, N.; Xia, Z. Synthesis, mechanistic investigation, and application of photoluminescent sulfur and nitrogen co-doped carbon dots. J. Mater. Chem. C 2015, 3, 9885-9893. [CrossRef] 
56. Zhao, C.; Jiao, Y.; Hua, J.; Yang, J.; Yang, Y. Hydrothermal Synthesis of Nitrogen-Doped Carbon Quantum Dots as Fluorescent Probes for the Detection of Dopamine. J. Fluoresc. 2018, 28, 269-276. [CrossRef] [PubMed]

57. Meng, Y.; Jiao, Y.; Zhang, Y.; Li, Y.; Gao, Y.; Lu, W.; Liu, Y.; Shuang, S.; Dong, C. Multi-sensing function integrated nitrogen-doped fluorescent carbon dots as the platform toward multi-mode detection and bioimaging. Talanta 2020, 210, 120653. [CrossRef]

58. Bandi, R.; Dadigala, R.; Gangapuram, B.R.; Sabir, F.K.; Alle, M.; Lee, S.H.; Guttena, V. N-Doped carbon dots with pH-sensitive emission, and their application to simultaneous fluorometric determination of iron (III) and copper (II). Mikrochim. Acta 2019, 187, 30. [CrossRef] [PubMed]

59. Shan, X.; Chai, L.; Ma, J.; Qian, Z.; Chen, J.; Feng, H. B-doped carbon quantum dots as a sensitive fluorescence probe for hydrogen peroxide and glucose detection. Analyst 2014, 139, 2322-2325. [CrossRef]

60. Zhang, X.; Ren, Y.; Ji, Z.; Fan, J. Sensitive detection of amoxicillin in aqueous solution with novel fluorescent probes containing boron-doped carbon quantum dots. J. Mol. Liq. 2020, 311, 113278. [CrossRef]

61. Jia, Y.; Hu, Y.; Li, Y.; Zeng, Q.; Jiang, X.; Cheng, Z. Boron doped carbon dots as a multifunctional fluorescent probe for sorbate and vitamin B12. Mikrochim. Acta 2019, 186, 84. [CrossRef]

62. Hu, Q.; Li, T.; Gao, L.; Gong, X.; Rao, S.; Fang, W.; Gu, R.; Yang, Z. Ultrafast and Energy-saving Synthesis of Nitrogen and Chlorine Co-doped Carbon Nanodots via Neutralization Heat for Selective Detection of Cr (VI) in Aqueous Phase. Sensors 2018, 18, 3416. [CrossRef] [PubMed]

63. Lin, L.; Wang, Y.; Xiao, Y.; Liu, W. Hydrothermal synthesis of carbon dots codoped with nitrogen and phosphorus as a turn-on fluorescent probe for cadmium (II). Mikrochim. Acta 2019, 186, 147. [CrossRef] [PubMed]

64. Omer, K.M. Highly passivated phosphorous and nitrogen co-doped carbon quantum dots and fluorometric assay for detection of copper ions. Anal. Bioanal. Chem. 2018, 410, 6331-6336. [CrossRef] [PubMed]

65. Liu, Y.; Gong, X.; Dong, W.; Zhou, R.; Shuang, S.; Dong, C. Nitrogen and phosphorus dual-doped carbon dots as a label-free sensor for Curcumin determination in real sample and cellular imaging. Talanta 2018, 183, 61-69. [CrossRef] [PubMed]

66. Zeng, Y.-W.; Ma, D.-K.; Wang, W.; Chen, J.-J.; Zhou, L.; Zheng, Y.-Z.; Yu, K.; Huang, S.-M. N, S co-doped carbon dots with orange luminescence synthesized through polymerization and carbonization reaction of amino acids. Appl. Surf. Sci. 2015, 342, 136-143. [CrossRef]

67. Liu, H.; Zhang, Y.; Huang, C. Development of nitrogen and sulfur-doped carbon dots for cellular imaging. J. Pharm. Anal. 2019, 9, 127-132. [CrossRef]

68. Li, F.; Li, Y.; Yang, X.; Han, X.; Jiao, Y.; Wei, T.; Yang, D.; Xu, H.; Nie, G. Highly Fluorescent Chiral N-S-Doped Carbon Dots from Cysteine: Affecting Cellular Energy Metabolism. Angew. Chem. Int. Ed. Engl. 2018, 57, 2377-2382. [CrossRef]

69. Ding, C.; Deng, Z.; Chen, J.; Jin, Y. One-step microwave synthesis of N, S co-doped carbon dots from 1,6-hexanediamine dihydrochloride for cell imaging and ion detection. Colloids Surf. B Biointerfaces 2020, 189, 110838. [CrossRef]

70. Ye, Q.; Yan, F.; Shi, D.; Zheng, T.; Wang, Y.; Zhou, X.; Chen, L. N, B-doped carbon dots as a sensitive fluorescence probe for Hg (2+) ions and 2,4,6-trinitrophenol detection for bioimaging. J. Photochem. Photobiol. B 2016, 162, 1-13. [CrossRef]

71. Jiang, X.; Qin, D.; Mo, G.; Feng, J.; Zheng, X.; Deng, B. Facile Preparation of Boron and Nitrogen Codoped Green Emission Carbon Quantum Dots for Detection of Permanganate and Captopril. Anal. Chem. 2019, 91, 11455-11460. [CrossRef] [PubMed]

72. Huang, S.; Yang, E.; Yao, J.; Liu, Y.; Xiao, Q. Carbon dots doped with nitrogen and boron as ultrasensitive fluorescent probes for determination of alpha-glucosidase activity and its inhibitors in water samples and living cells. Mikrochim. Acta 2018, 185, 394. [CrossRef]

73. Alizadeh, N.; Salimi, A.; Hallaj, R. A strategy for visual optical determination of glucose based on a smartphone device using fluorescent boron-doped carbon nanoparticles as a light-up probe. Mikrochim. Acta 2019, 187, 14. [CrossRef]

74. Gao, Z.; Liu, M.; Xu, K.; Tang, M.; Lin, X.; Hu, S.; Ren, X. Facile fabrication of N/S/P tri-doped carbon dots for tetracycline detection by an internal filtering effect of a two-way matching strategy. Anal. Methods 2020, 12, 2551-2554. [CrossRef] [PubMed]

75. Huang, S.; Yang, E.; Yao, J.; Chu, X.; Liu, Y.; Xiao, Q. Nitrogen, phosphorus and sulfur tri-doped carbon dots are specific and sensitive fluorescent probes for determination of chromium (VI) in water samples and in living cells. Mikrochim. Acta 2019, 186, 851. [CrossRef] [PubMed]

76. Huang, S.; Yang, E.; Yao, J.; Liu, Y.; Xiao, Q. Red emission nitrogen, boron, sulfur co-doped carbon dots for "on-off-on" fluorescent mode detection of $\mathrm{Ag}(+)$ ions and l-cysteine in complex biological fluids and living cells. Anal. Chim. Acta 2018, 1035, 192-202. [CrossRef] [PubMed]

77. Liu, W.; Li, C.; Ren, Y.; Sun, X.; Pan, W.; Li, Y.; Wang, J.; Wang, W. Carbon dots: Surface engineering and applications. J. Mater. Chem. B 2016, 4, 5772-5788. [CrossRef]

78. Gao, M.X.; Yang, L.; Zheng, Y.; Yang, X.X.; Zou, H.Y.; Han, J.; Liu, Z.X.; Li, Y.F.; Huang, C.Z. “Click” on Alkynylated Carbon Quantum Dots: An Efficient Surface Functionalization for Specific Biosensing and Bioimaging. Chemistry 2017, 23, $2171-2178$. [CrossRef]

79. Dimos, K. Tuning Carbon Dots' Optoelectronic Properties with Polymers. Polymers 2018, 10, 1312. [CrossRef]

80. Kavitha, T.; Kim, J.O.; Jang, S.; Kim, D.P.; Kang, I.K.; Park, S.Y. Multifaceted thermoresponsive poly (N-vinylcaprolactam) coupled with carbon dots for biomedical applications. Mater. Sci. Eng. C 2016, 61, 492-498. [CrossRef] [PubMed]

81. Abu Rabe, D.I.; Al Awak, M.M.; Yang, F.; Okonjo, P.A.; Dong, X.; Teisl, L.R.; Wang, P.; Tang, Y.; Pan, N.; Sun, Y.P.; et al. The dominant role of surface functionalization in carbon dots' photo-activated antibacterial activity. Int. J. Nanomed. 2019, 14, 2655. [CrossRef] 
82. Ostadhossein, F.; Vulugundam, G.; Misra, S.K.; Srivastava, I.; Pan, D. Chirality Inversion on the Carbon Dot Surface via Covalent Surface Conjugation of Cyclic Alpha-Amino Acid Capping Agents. Bioconjug. Chem. 2018, 29, 3913-3922. [CrossRef]

83. Kim, Y.; Kim, J. Bioinspired thiol functionalized carbon dots for rapid detection of lead (II) ions in human serum. Opt. Mater. 2020, 99, 109514. [CrossRef]

84. Rossini, E.L.; Milani, M.I.; Pezza, H.R. Green synthesis of fluorescent carbon dots for determination of glucose in biofluids using a paper platform. Talanta 2019, 201, 503-510. [CrossRef] [PubMed]

85. Fahmi, M.Z.; Wibowo, D.L.N.; Sakti, S.C.W.; Lee, H.V. Human serum albumin capsulated hydrophobic carbon nanodots as staining agent on HeLa tumor cell. Mater. Chem. Phys. 2020, 239, 122266. [CrossRef]

86. Sahu, V.; Khan, F. Synthesis of bovine serum albumin capped boron-doped carbon dots for sensitive and selective detection of $\mathrm{Pb}$ (II) ion. Heliyon 2020, 6, e03957. [CrossRef]

87. Yang, T.; Huang, J.L.; Wang, Y.T.; Zheng, A.Q.; Shu, Y.; Wang, J.H. $\beta$-Cyclodextrin-Decorated Carbon Dots Serve as Nanocarriers for Targeted Drug Delivery and Controlled Release. ChemNanoMat 2019, 5, 479-487. [CrossRef]

88. Chen, Q.; Man, H.; Zhu, L.; Guo, Z.; Wang, X.; Tu, J.; Jin, G.; Lou, J.; Zhang, L.; Ci, L. Enhanced plant antioxidant capacity and biodegradation of phenol by immobilizing peroxidase on amphoteric nitrogen-doped carbon dots. Catal. Commun. 2020, 134, 105847. [CrossRef]

89. He, X.; Chen, P.; Zhang, J.; Luo, T.Y.; Wang, H.J.; Liu, Y.H.; Yu, X.Q. Cationic polymer-derived carbon dots for enhanced gene delivery and cell imaging. Biomater. Sci. 2019, 7, 1940-1948. [CrossRef]

90. Janus, L.; Piatkowski, M.; Radwan-Praglowska, A.J. Microwave-Assisted Synthesis and Characterization of Poly (L-lysine)-Based Polymer/Carbon Quantum Dot Nanomaterials for Biomedical Purposes. Materials 2019, 12, 3825. [CrossRef]

91. Arsalani, N.; Nezhad-Mokhtari, P.; Jabbari, E. Microwave-assisted and one-step synthesis of PEG passivated fluorescent carbon dots from gelatin as an efficient nanocarrier for methotrexate delivery. Artif. Cells Nanomed. Biotechnol. 2019, 47, 540-547. [CrossRef]

92. Li, L.; Zhao, F.; Zhang, T.; Lü, C. A facile method to prepare polymer functionalized carbon dots inspired by the mussel chemistry for LED application. Dyes Pigments 2019, 162, 845-854. [CrossRef]

93. Chen, C.-Y.; Tsai, Y.-H.; Chang, C.-W. Evaluation of the dialysis time required for carbon dots by HPLC and the properties of carbon dots after HPLC fractionation. New J. Chem. 2019, 43, 6153-6159. [CrossRef]

94. Vinci, J.C.; Colon, L.A. Fractionation of carbon-based nanomaterials by anion-exchange HPLC. Anal. Chem. 2012, 84, 1178-1183. [CrossRef] [PubMed]

95. Liu, L.; Xu, Z. Study of chromatographic fractions from carbon dots isolated by column chromatography and a binary gradient elution via RP-HPLC. Anal. Methods 2019, 11, 760-766. [CrossRef]

96. Kokorina, A.A.; Bakal, A.A.; Shpuntova, D.V.; Kostritskiy, A.Y.; Beloglazova, N.V.; De Saeger, S.; Sukhorukov, G.B.; Sapelkin, A.V.; Goryacheva, I.Y. Gel electrophoresis separation and origins of light emission in fluorophores prepared from citric acid and ethylenediamine. Sci. Rep. 2019, 9, 14665. [CrossRef] [PubMed]

97. Li, P.; Kumar, A.; Ma, J.; Kuang, Y.; Luo, L.; Sun, X. Density gradient ultracentrifugation for colloidal nanostructures separation and investigation. Sci. Bull. 2018, 63, 645-662. [CrossRef]

98. Beiraghi, A.; Najibi-Gehraz, S.A. Purification and Fractionation of Carbon Dots using pH-controlled Cloud Point Extraction Technique. J. Nanostruct. 2020, 10, 107-118. [CrossRef]

99. Uthirakumar, P.; Devendiran, M.; Kim, T.H.; Lee, I.-H. A convenient method for isolating carbon quantum dots in high yield as an alternative to the dialysis process and the fabrication of a full-band UV blocking polymer film. New J. Chem. 2018, 42, 18312-18317. [CrossRef]

100. Kokorina, A.A.; Prikhozhdenko, E.S.; Tarakina, N.V.; Sapelkin, A.V.; Sukhorukov, G.B.; Goryacheva, I.Y. Dispersion of optical and structural properties in gel column separated carbon nanoparticles. Carbon 2018, 127, 541-547. [CrossRef]

101. Hinterberger, V.; Damm, C.; Haines, P.; Guldi, D.M.; Peukert, W. Purification and structural elucidation of carbon dots by column chromatography. Nanoscale 2019, 11, 8464-8474. [CrossRef] [PubMed]

102. Vinci, J.C.; Ferrer, I.M.; Seedhouse, S.J.; Bourdon, A.K.; Reynard, J.M.; Foster, B.A.; Bright, F.V.; Colon, L.A. Hidden Properties of Carbon Dots Revealed After HPLC Fractionation. J. Phys. Chem. Lett. 2013, 4, 239-243. [CrossRef] [PubMed]

103. Somani, D.P.; Umeno, M. Importance of Transmission Electron Microscopy for Carbon Nanomaterials Research. Mod. Res. Educ. Top. Microsc. 2007, 3, 634-642.

104. Choudhary, O.P.; Choudhary, P. Scanning Electron Microscope: Advantages and Disadvantages in Imaging Components. Int. J. Curr. Microbiol. Appl. Sci. 2017, 6, 1877-1882. [CrossRef]

105. Jlassi, K.; Eid, K.; Sliem, M.; Abdullah, A.; Chehimi, M.; Krupa, I. Rational synthesis, characterization, and application of environmentally friendly (polymer-carbon dot) hybrid composite film for fast and efficient UV-assisted Cd2+ removal from water. Environ. Sci. Eur. 2020, 32, 1-13. [CrossRef]

106. García, R. Dynamic atomic force microscopy methods. Surf. Sci. Rep. 2002, 47, 197-301. [CrossRef]

107. Muller, D.J.; Dufrene, Y.F. Atomic force microscopy as a multifunctional molecular toolbox in nanobiotechnology. In Nanoscience and Technology; World Scientific: Singapore, 2009; pp. 269-277. [CrossRef]

108. Huang, J.J.; Zhong, Z.F.; Rong, M.Z.; Zhou, X.; Chen, X.D.; Zhang, M.Q. An easy approach of preparing strongly luminescent carbon dots and their polymer based composites for enhancing solar cell efficiency. Carbon 2014, 70, 190-198. [CrossRef] 
109. Bishnoi, A.; Kumar, S.; Joshi, N. Wide-Angle X-ray Diffraction (WXRD). In Microscopy Methods in Nanomaterials Characterization; Thomas, S., Thomas, R., Zachariah, A.K., Mishra, R.K., Eds.; Elsevier: Amsterdam, The Netherlands, 2017 ; pp. $313-337$.

110. Hu, Q.; Paau, M.C.; Zhang, Y.; Gong, X.; Zhang, L.; Lu, D.; Liu, Y.; Liu, Q.; Yao, J.; Choi, M.M.F. Green synthesis of fluorescent nitrogen/sulfur-doped carbon dots and investigation of their properties by HPLC coupled with mass spectrometry. RSC Adv. 2014, 4, 18065-18073. [CrossRef]

111. Li, X.; Zhang, S.; Kulinich, S.A.; Liu, Y.; Zeng, H. Engineering surface states of carbon dots to achieve controllable luminescence for solid-luminescent composites and sensitive Be2+ detection. Sci. Rep. 2014, 4, 4976. [CrossRef]

112. Hu, Y.; Yang, J.; Tian, J.; Jia, L.; Yu, J.-S. Waste frying oil as a precursor for one-step synthesis of sulfur-doped carbon dots with $\mathrm{pH}$-sensitive photoluminescence. Carbon 2014, 77, 775-782. [CrossRef]

113. Kundu, A.; Lee, J.; Park, B.; Ray, C.; Sankar, K.V.; Kim, W.S.; Lee, S.H.; Cho, I.J.; Jun, S.C. Facile approach to synthesize highly fluorescent multicolor emissive carbon dots via surface functionalization for cellular imaging. J. Colloid Interface Sci. 2018, 513, 505-514. [CrossRef]

114. Zhou, Y.; Zahran, E.M.; Quiroga, B.A.; Perez, J.; Mintz, K.J.; Peng, Z.; Liyanage, P.Y.; Pandey, R.R.; Chusuei, C.C.; Leblanc, R.M. Size-Dependent Photocatalytic Activity of Carbon Dots with Surface-State Determined Photoluminescence. Appl. Catal. B 2019, 248, 157-166. [CrossRef]

115. Fang, Y.; Guo, S.; Li, D.; Zhu, C.; Ren, W.; Dong, S.; Wang, E. Easy synthesis and imaging applications of cross-linked green fluorescent hollow carbon nanoparticles. ACS Nano 2012, 6, 400-409. [CrossRef]

116. Tougaard, S. Surface analysis X-ray Photoelectron Spectroscopy. In Reference Module in Chemistry, Molecular Sciences and Chemical Engineering; Elsevier: Amsterdam, The Netherlands, 2013. [CrossRef]

117. Ebnesajjad, S. Surface and Material Characterization Techniques. In Surface Treatment of Materials for Adhesive Bonding; Ebnesajjad, S., Ed.; William Andrew: Oxford, UK, 2014; pp. 39-75. [CrossRef]

118. Zheng, L.; Qi, P.; Zhang, D. Identification of bacteria by a fluorescence sensor array based on three kinds of receptors functionalized carbon dots. Sens. Actuators B Chem. 2019, 286, 206-213. [CrossRef]

119. Yang, Y.Z.; Xiao, N.; Liu, S.G.; Han, L.; Li, N.B.; Luo, H.Q. pH-induced aggregation of hydrophilic carbon dots for fluorescence detection of acidic amino acid and intracellular pH imaging. Mater. Sci. Eng. C 2020, 108, 110401. [CrossRef]

120. Zhong, J.; Chen, X.; Zhang, M.; Xiao, C.; Cai, L.; Khan, W.A.; Yu, K.; Cui, J.; He, L. Blood compatible heteratom-doped carbon dots for bio-imaging of human umbilical vein endothelial cells. Chin. Chem. Lett. 2020, 31, 769-773. [CrossRef]

121. Shi, X.; Hu, Y.; Meng, H.-M.; Yang, J.; Qu, L.; Zhang, X.-B.; Li, Z. Red emissive carbon dots with dual targetability for imaging polarity in living cells. Sens. Actuators B Chem. 2020, 306, 127582. [CrossRef]

122. Sun, Y.; Zheng, S.; Liu, L.; Kong, Y.; Zhang, A.; Xu, K.; Han, C. The Cost-Effective Preparation of Green Fluorescent Carbon Dots for Bioimaging and Enhanced Intracellular Drug Delivery. Nanoscale Res. Lett. 2020, 15, 55. [CrossRef] [PubMed]

123. Li, J.; Li, M.; Tian, L.; Qiu, Y.; Yu, Q.; Wang, X.; Guo, R.; He, Q. Facile strategy by hyaluronic acid functional carbon dot-doxorubicin nanoparticles for CD44 targeted drug delivery and enhanced breast cancer therapy. Int. J. Pharm. 2020, 578, 119122. [CrossRef] [PubMed]

124. Duan, Q.; Ma, L.; Zhang, B.; Zhang, Y.; Li, X.; Wang, T.; Zhang, W.; Li, Y.; Sang, S. Construction and application of targeted drug delivery system based on hyaluronic acid and heparin functionalised carbon dots. Colloids Surf. B Biointerfaces 2020, 188, 110768. [CrossRef] [PubMed]

125. Hettiarachchi, S.D.; Graham, R.M.; Mintz, K.J.; Zhou, Y.; Vanni, S.; Peng, Z.; Leblanc, R.M. Triple conjugated carbon dots as a nano-drug delivery model for glioblastoma brain tumors. Nanoscale 2019, 11, 6192-6205. [CrossRef] [PubMed]

126. Shu, M.; Gao, F.; Yu, C.; Zeng, M.; He, G.; Wu, Y.; Su, Y.; Hu, N.; Zhou, Z.; Yang, Z.; et al. Dual-targeted therapy in HER2positive breast cancer cells with the combination of carbon dots/HER3 siRNA and trastuzumab. Nanotechnology 2020, 31, 335102 [CrossRef] [PubMed]

127. Jin, N.; Jin, N.; Wang, Z.; Liu, L.; Meng, L.; Li, D.; Li, X.; Zhou, D.; Liu, J.; Bu, W.; et al. Osteopromotive carbon dots promote bone regeneration through the PERK-eIF2alpha-ATF4 pathway. Biomater. Sci. 2020, 8, 2840-2852. [CrossRef] [PubMed]

128. Malishev, R.; Arad, E.; Bhunia, S.K.; Shaham-Niv, S.; Kolusheva, S.; Gazit, E.; Jelinek, R. Chiral modulation of amyloid beta fibrillation and cytotoxicity by enantiomeric carbon dots. Chem. Commun. 2018, 54, 7762-7765. [CrossRef] [PubMed]

129. Chen, P.; Zhang, J.; He, X.; Liu, Y.H.; Yu, X.Q. Hydrophobically modified carbon dots as a multifunctional platform for serumresistant gene delivery and cell imaging. Biomater. Sci. 2020, 8, 3730-3740. [CrossRef] [PubMed]

130. Ju, E.; Li, T.; Liu, Z.; Da Silva, S.R.; Wei, S.; Zhang, X.; Wang, X.; Gao, S.J. Specific Inhibition of Viral MicroRNAs by Carbon Dots-Mediated Delivery of Locked Nucleic Acids for Therapy of Virus-Induced Cancer. ACS Nano 2020, 14, 476-487. [CrossRef] [PubMed]

131. Muktha, H.; Sharath, R.; Kottam, N.; Smrithi, S.P.; Samrat, K.; Ankitha, P. Green Synthesis of Carbon Dots and Evaluation of Its Pharmacological Activities. BioNanoScience 2020, 10, 731-744. [CrossRef]

132. Gao, G.; Jiang, Y.-W.; Jia, H.-R.; Yang, J.; Wu, F.-G. On-off-on fluorescent nanosensor for Fe3+ detection and cancer/normal cell differentiation via silicon-doped carbon quantum dots. Carbon 2018, 134, 232-243. [CrossRef]

133. Hua, X.-W.; Bao, Y.-W.; Wu, F.-G. Fluorescent Carbon Quantum Dots with Intrinsic Nucleolus-Targeting Capability for Nucleolus Imaging and Enhanced Cytosolic and Nuclear Drug Delivery. ACS Appl. Mater. Interfaces 2018, 10, 10664-10677. [CrossRef] 
134. Singh, V.; Rawat, K.S.; Mishra, S.; Baghel, T.; Fatima, S.; John, A.A.; Kalleti, N.; Singh, D.; Nazir, A.; Rath, S.K.; et al. Biocompatible fluorescent carbon quantum dots prepared from beetroot extract for in vivo live imaging in C elegans and BALB/c mice. J. Mater. Chem. B 2018, 6, 3366-3371. [CrossRef]

135. Zuo, G.; Xie, A.; Pan, X.; Su, T.; Li, J.; Dong, W. Fluorine-Doped Cationic Carbon Dots for Efficient Gene Delivery. ACS Appl. Nano Mater. 2018, 1, 2376-2385. [CrossRef]

136. Ardekani, S.M.; Dehghani, A.; Ye, P.; Nguyen, K.-A.; Gomes, V.G. Conjugated carbon quantum dots: Potent nano-antibiotic for intracellular pathogens. J. Colloid Interface Sci. 2019, 552, 378-387. [CrossRef] [PubMed]

137. Ghosh, S.; Ghosal, K.; Mohammad, S.A.; Sarkar, K. Dendrimer functionalized carbon quantum dot for selective detection of breast cancer and gene therapy. Chem. Eng. J. 2019, 373, 468-484. [CrossRef]

138. Demirci, S.; McNally, A.B.; Ayyala, R.S.; Lawson, L.B.; Sahiner, N. Synthesis and characterization of nitrogen-doped carbon dots as fluorescent nanoprobes with antimicrobial properties and skin permeability. J. Drug Deliv. Sci. Technol. 2020, 59, 101889. [CrossRef]

139. Huang, S.; Li, B.; Ashraf, U.; Li, Q.; Lu, X.; Gao, X.; Cui, M.; Imran, M.; Ye, J.; Cao, F.; et al. Quaternized Cationic Carbon Dots as Antigen Delivery Systems for Improving Humoral and Cellular Immune Responses. ACS Appl. Nano Mater. 2020 , 3, $9449-9461$. [CrossRef]

140. Li, S.; Su, W.; Wu, H.; Yuan, T.; Yuan, C.; Liu, J.; Deng, G.; Gao, X.; Chen, Z.; Bao, Y.; et al. Targeted tumour theranostics in mice via carbon quantum dots structurally mimicking large amino acids. Nat. Biomed. Eng. 2020, 4, 704-716. [CrossRef] [PubMed]

141. Qu, Z.; Liu, L.; Sun, T.; Hou, J.; Sun, Y.; Yu, M.; Diao, Y.; Lu, S.; Zhao, W.; Wang, L. Synthesis of bifunctional carbon quantum dots for bioimaging and anti-inflammation. Nanotechnology 2020, 31, 175102. [CrossRef] [PubMed]

142. Shukla, D.; Das, M.; Kasade, D.; Pandey, M.; Dubey, A.K.; Yadav, S.K.; Parmar, A.S. Sandalwood-derived carbon quantum dots as bioimaging tools to investigate the toxicological effects of malachite green in model organisms. Chemosphere 2020, 248, 125998 [CrossRef] [PubMed]

143. Liu, Y.; Li, W.; Wu, P.; Ma, C.; Wu, X.; Xu, M.; Luo, S.; Xu, Z.; Liu, S. Hydrothermal synthesis of nitrogen and boron co-doped carbon quantum dots for application in acetone and dopamine sensors and multicolor cellular imaging. Sens. Actuators $B$ Chem. 2019, 281, 34-43. [CrossRef]

144. Wu, W.; Zheng, T.; Tian, Y. An enzyme-free amplification strategy based on two-photon fluorescent carbon dots for monitoring miR-9 in live neurons and brain tissues of Alzheimer's disease mice. Chem. Commun. 2020, 56, 8083-8086. [CrossRef]

145. Zhang, C.; Wu, S.; Yu, Y.; Chen, F. Determination of thiourea based on the reversion of fluorescence quenching of nitrogen doped carbon dots by $\mathrm{Hg}$ (2). Spectrochim. Acta A Mol. Biomol. Spectrosc. 2020, 227, 117666. [CrossRef]

146. Ma, Y.; Chen, A.Y.; Huang, Y.Y.; He, X.; Xie, X.F.; He, B.; Yang, J.H.; Wang, X.Y. Off-on fluorescent switching of boron-doped carbon quantum dots for ultrasensitive sensing of catechol and glutathione. Carbon 2020, 162, 234-244. [CrossRef]

147. Wang, C.; Lan, Y.; Yuan, F.; Fereja, T.H.; Lou, B.; Han, S.; Li, J.; Xu, G. Chemiluminescent determination of L-cysteine with the lucigenin-carbon dot system. Mikrochim. Acta 2019, 187, 50. [CrossRef]

148. Zhang, R.; Fan, Z. Nitrogen-doped carbon quantum dots as a "turn off-on" fluorescence sensor based on the redox reaction mechanism for the sensitive detection of dopamine and alpha lipoic acid. J. Photochem. Photobiol. A Chem. 2020, $392,112438$. [CrossRef]

149. Yue, J.; Li, L.; Cao, L.; Zan, M.; Yang, D.; Wang, Z.; Chang, Z.; Mei, Q.; Miao, P.; Dong, W.F. Two-Step Hydrothermal Preparation of Carbon Dots for Calcium Ion Detection. ACS Appl. Mater. Interfaces 2019, 11, 44566-44572. [CrossRef]

150. Singh, J.; Kaur, S.; Lee, J.; Mehta, A.; Kumar, S.; Kim, K.H.; Basu, S.; Rawat, M. Highly fluorescent carbon dots derived from Mangifera indica leaves for selective detection of metal ions. Sci. Total Environ. 2020, 720, 137604. [CrossRef]

151. Ali, H.R.H.; Hassan, A.I.; Hassan, Y.F.; El-Wekil, M.M. Development of dual function polyamine-functionalized carbon dots derived from one step green synthesis for quantitation of $\mathrm{Cu}(2+)$ and $\mathrm{S}(2-)$ ions in complicated matrices with high selectivity. Anal. Bioanal. Chem. 2020, 412, 1353-1363. [CrossRef] [PubMed]

152. Sinha, R.; Bidkar, A.P.; Rajasekhar, R.; Ghosh, S.S.; Mandal, T.K. A facile synthesis of nontoxic luminescent carbon dots for detection of chromium and iron in real water sample and bio-imaging. Can. J. Chem. Eng. 2019, 98, 194-204. [CrossRef]

153. Wu, F.; Yang, M.; Zhang, H.; Zhu, S.; Zhu, X.; Wang, K. Facile synthesis of sulfur-doped carbon quantum dots from vitamin B1 for highly selective detection of Fe3+ ion. Opt. Mater. 2018, 77, 258-263. [CrossRef]

154. Yang, P.; Zhu, Z.; Chen, M.; Chen, W.; Zhou, X. Microwave-assisted synthesis of xylan-derived carbon quantum dots for tetracycline sensing. Opt. Mater. 2018, 85, 329-336. [CrossRef]

155. Zhang, Q.Q.; Chen, B.B.; Zou, H.Y.; Li, Y.F.; Huang, C.Z. Inner filter with carbon quantum dots: A selective sensing platform for detection of hematin in human red cells. Biosens. Bioelectron. 2018, 100, 148-154. [CrossRef]

156. Zhong, Q.; Chen, Y.; Su, A.; Wang, Y. Synthesis of catalytically active carbon quantum dots and its application for colorimetric detection of glutathione. Sens. Actuators B Chem. 2018, 273, 1098-1102. [CrossRef]

157. Carneiro, S.V.; De Queiroz, V.H.R.; Cruz, A.A.C.; Fechine, L.M.U.D.; Denardin, J.C.; Freire, R.M.; Do Nascimento, R.F.; Fechine, P.B.A. Sensing strategy based on Carbon Quantum Dots obtained from riboflavin for the identification of pesticides. Sens. Actuators B Chem. 2019, 301, 127149. [CrossRef]

158. Chandra, S.; Singh, V.K.; Yadav, P.K.; Bano, D.; Kumar, V.; Pandey, V.K.; Talat, M.; Hasan, S.H. Mustard seeds derived fluorescent carbon quantum dots and their peroxidase-like activity for colorimetric detection of $\mathrm{H} 2 \mathrm{O} 2$ and ascorbic acid in a real sample. Anal. Chim. Acta 2019, 1054, 145-156. [CrossRef] 
159. Lu, C.; Liu, J.; Gan, L.; Yang, X. Employing Cryptococcus-directed carbon dots for differentiating and detecting m-benzenediol and p-benzenediol. Sens. Actuators B Chem. 2019, 301, 127077. [CrossRef]

160. Murugan, N.; Prakash, M.; Jayakumar, M.; Sundaramurthy, A.; Sundramoorthy, A.K. Green synthesis of fluorescent carbon quantum dots from Eleusine coracana and their application as a fluorescence 'turn-off' sensor probe for selective detection of Cu2+. Appl. Surf. Sci. 2019, 476, 468-480. [CrossRef]

161. Guo, Y.; Zhao, W. Hydrothermal synthesis of highly fluorescent nitrogen-doped carbon quantum dots with good biocompatibility and the application for sensing ellagic acid. Spectrochim. Acta Part A Mol. Biomol. Spectrosc. 2020, 240, 118580. [CrossRef] [PubMed]

162. Liu, H.; Ding, J.; Chen, L.; Ding, L. A novel fluorescence assay based on self-doping biomass carbon dots for rapid detection of dimethoate. J. Photochem. Photobiol. A Chem. 2020, 400, 112724. [CrossRef]

163. Liu, L.; Hu, Q.; Sun, H.; Han, J.; Pan, Y.; Yang, Z.-Q. An ultra-sensitive analytical platform based on bluish green emitting carbon quantum dots for the detection of curcumin in dietary foods. J. Food Compos. Anal. 2020, 94, 103639. [CrossRef]

164. Shekarbeygi, Z.; Farhadian, N.; Khani, S.; Moradi, S.; Shahlaei, M. The effects of rose pigments extracted by different methods on the optical properties of carbon quantum dots and its efficacy in the determination of Diazinon. Microchem. J. 2020, 158, 105232. [CrossRef]

165. Wang, X.; Yu, S.; Wang, J.; Yu, J.; Arabi, M.; Fu, L.; Li, B.; Li, J.; Chen, L. Fluorescent nanosensor designing via hybrid of carbon dots and post-imprinted polymers for the detection of ovalbumin. Talanta 2020, 211, 120727. [CrossRef]

166. Yuan, F.; Yuan, T.; Sui, L.; Wang, Z.; Xi, Z.; Li, Y.; Li, X.; Fan, L.; Tan, Z.; Chen, A.; et al. Engineering triangular carbon quantum dots with unprecedented narrow bandwidth emission for multicolored LEDs. Nat. Commun. 2018, 9, 2249. [CrossRef]

167. Guner, T.; Yuce, H.; Tascioglu, D.; Simsek, E.; Savaci, U.; Genc, A.; Turan, S.; Demir, M.M. Optimization and performance of nitrogen-doped carbon dots as a color conversion layer for white-LED applications. Beilstein J. Nanotechnol. 2019, 10, $2004-2013$. [CrossRef] [PubMed]

168. Paulo-Mirasol, S.; Gené-Marimon, S.; Martínez-Ferrero, E.; Palomares, E. Inverted Hybrid Light-Emitting Diodes Using Carbon Dots as Selective Contacts: The Effect of Surface Ligands. ACS Appl. Electron. Mater. 2020, 2, 1388-1394. [CrossRef]

169. Zheng, J.; Xie, Y.; Wei, Y.; Yang, Y.; Liu, X.; Chen, Y.; Xu, B. An Efficient Synthesis and Photoelectric Properties of Green Carbon Quantum Dots with High Fluorescent Quantum Yield. Nanomaterials 2020, 10, 82. [CrossRef] [PubMed]

170. Wang, L.; Li, W.; Yin, L.; Liu, Y.; Guo, H.; Lai, J.; Han, Y.; Li, G.; Li, M.; Zhang, J.; et al. Full-color fluorescent carbon quantum dots. Sci. Adv. 2020, 6, eabb6772. [CrossRef]

171. Padmanathan, S.; Prakasam, A. Design and fabrication of hybrid carbon dots/titanium dioxide (CDs/TiO2) photoelectrodes for highly efficient dye-sensitized solar cells. J. Mater. Sci. Mater. Electron. 2020, 31, 3492-3499. [CrossRef]

172. Zhao, H.; Benetti, D.; Tong, X.; Zhang, H.; Zhou, Y.; Liu, G.; Ma, D.; Sun, S.; Wang, Z.M.; Wang, Y.; et al. Efficient and stable tandem luminescent solar concentrators based on carbon dots and perovskite quantum dots. Nano Energy 2018, 50, 756-765. [CrossRef]

173. Wang, Z.; Zhao, X.; Guo, Z.; Miao, P.; Gong, X. Carbon dots based nanocomposite thin film for highly efficient luminescent solar concentrators. Org. Electron. 2018, 62, 284-289. [CrossRef]

174. Dai, D.; Tu, X.; Li, X.; Lv, T.; Han, F. Tuning solar absorption spectra via carbon quantum dots/VAE composite layer and efficiency enhancement for crystalline Si solar module. Prog. Photovolt. Res. Appl. 2019, 27, 283-289. [CrossRef]

175. Liu, L.; Yu, X.; Yi, Z.; Chi, F.; Wang, H.; Yuan, Y.; Li, D.; Xu, K.; Zhang, X. High efficiency solar cells tailored using biomassconverted graded carbon quantum dots. Nanoscale 2019, 11, 15083-15090. [CrossRef]

176. Mistry, B.; Machhi, H.K.; Vithalani, R.S.; Patel, D.S.; Modi, C.K.; Prajapati, M.; Surati, K.R.; Soni, S.S.; Jha, P.K.; Kane, S.R. Harnessing the N-dopant ratio in carbon quantum dots for enhancing the power conversion efficiency of solar cells. Sustain. Energy Fuels 2019, 3, 3182-3190. [CrossRef]

177. Zhao, H.; Liu, G.; Han, G. High-performance laminated luminescent solar concentrators based on colloidal carbon quantum dots. Nanoscale Adv. 2019, 1, 4888-4894. [CrossRef]

178. Sabet, M.; Mahdavi, K. Green synthesis of high photoluminescence nitrogen-doped carbon quantum dots from grass via a simple hydrothermal method for removing organic and inorganic water pollutions. Appl. Surf. Sci. 2019, 463, 283-291. [CrossRef]

179. Zhu, Z.; Yang, P.; Li, X.; Luo, M.; Zhang, W.; Chen, M.; Zhou, X. Green preparation of palm powder-derived carbon dots co-doped with sulfur/chlorine and their application in visible-light photocatalysis. Spectrochim. Acta A Mol. Biomol. Spectrosc. 2020, 227, 117659. [CrossRef] [PubMed]

180. Amadio, E.; Cailotto, S.; Campalani, C.; Branzi, L.; Raviola, C.; Ravelli, D.; Cattaruzza, E.; Trave, E.; Benedetti, A.; Selva, M.; et al. Precursor-Dependent Photocatalytic Activity of Carbon Dots. Molecules 2019, 25, 101.

181. Ji, M.; Zhang, Z.; Xia, J.; Di, J.; Liu, Y.; Chen, R.; Yin, S.; Zhang, S.; Li, H. Enhanced photocatalytic performance of carbon quantum dots/BiOBr composite and mechanism investigation. Chin. Chem. Lett. 2018, 29, 805-810. [CrossRef]

182. Kováčová, M.; Marković, Z.M.; Humpolíček, P.; Mičušík, M.; Švajdlenková, H.; Kleinová, A.; Danko, M.; Kubát, P.; Vajd'ák, J.; Capáková, Z.; et al. Carbon Quantum Dots Modified Polyurethane Nanocomposite as Effective Photocatalytic and Antibacterial Agents. ACS Biomater. Sci. Eng. 2018, 4, 3983-3993. [CrossRef]

183. Li, M.; Wang, M.; Zhu, L.; Li, Y.; Yan, Z.; Shen, Z.; Cao, X. Facile microwave assisted synthesis of N-rich carbon quantum dots/dual-phase $\mathrm{TiO} 2$ heterostructured nanocomposites with high activity in $\mathrm{CO} 2$ photoreduction. Appl. Catal. B Environ. 2018, 231, 269-276. [CrossRef] 
184. Zhang, J.; Yuan, X.; Jiang, L.; Wu, Z.; Chen, X.; Wang, H.; Wang, H.; Zeng, G. Highly efficient photocatalysis toward tetracycline of nitrogen doped carbon quantum dots sensitized bismuth tungstate based on interfacial charge transfer. J. Colloid Interface Sci. 2018, 511, 296-306. [CrossRef]

185. Qu, Z.; Wang, J.; Tang, J.; Shu, X.; Liu, X.; Zhang, Z.; Wang, J. Carbon quantum dots/KNbO3 hybrid composites with enhanced visible-light driven photocatalytic activity toward dye waste-water degradation and hydrogen production. Mol. Catal. 2018, 445, 1-11. [CrossRef]

186. Chen, Q.; Chen, L.; Qi, J.; Tong, Y.; Lv, Y.; Xu, C.; Ni, J.; Liu, W. Photocatalytic degradation of amoxicillin by carbon quantum dots modified K2Ti6O13 nanotubes: Effect of light wavelength. Chin. Chem. Lett. 2019, 30, 1214-1218. [CrossRef]

187. Di, G.; Zhu, Z.; Dai, Q.; Zhang, H.; Shen, X.; Qiu, Y.; Huang, Y.; Yu, J.; Yin, D.; Küppers, S. Wavelength-dependent effects of carbon quantum dots on the photocatalytic activity of g-C3N4 enabled by LEDs. Chem. Eng. J. 2020, 379, 122296. [CrossRef]

188. Hu, Y.; Guan, R.; Zhang, C.; Zhang, K.; Liu, W.; Shao, X.; Xue, Q.; Yue, Q. Fluorescence and photocatalytic activity of metal-free nitrogen-doped carbon quantum dots with varying nitrogen contents. Appl. Surf. Sci. 2020, 531, 147344. [CrossRef]

189. Mahmood, A.; Shi, G.; Wang, Z.; Rao, Z.; Xiao, W.; Xie, X.; Sun, J. Carbon quantum dots-TiO2 nanocomposite as an efficient photocatalyst for the photodegradation of aromatic ring-containing mixed VOCs: An experimental and DFT studies of adsorption and electronic structure of the interface. J. Hazard. Mater. 2021, 401, 123402. [CrossRef] [PubMed]

190. Travlou, N.A.; Giannakoudakis, D.A.; Algarra, M.; Labella, A.M.; Rodríguez-Castellón, E.; Bandosz, T.J. S and N-doped carbon quantum dots: Surface chemistry dependent antibacterial activity. Carbon 2018, 135, 104-111. [CrossRef]

191. Song, Y.; Lu, F.; Li, H.; Wang, H.; Zhang, M.; Liu, Y.; Kang, Z. Degradable Carbon Dots from Cigarette Smoking with BroadSpectrum Antimicrobial Activities against Drug-Resistant Bacteria. ACS Appl. Bio Mater. 2018, 1, 1871-1879. [CrossRef]

192. Li, H.; Huang, J.; Song, Y.; Zhang, M.; Wang, H.; Lu, F.; Huang, H.; Liu, Y.; Dai, X.; Gu, Z.; et al. Degradable Carbon Dots with Broad-Spectrum Antibacterial Activity. ACS Appl. Mater. Interfaces 2018, 10, 26936-26946. [CrossRef]

193. Loczechin, A.; Seron, K.; Barras, A.; Giovanelli, E.; Belouzard, S.; Chen, Y.T.; Metzler-Nolte, N.; Boukherroub, R.; Dubuisson, J.; Szunerits, S. Functional Carbon Quantum Dots as Medical Countermeasures to Human Coronavirus. ACS Appl. Mater. Interfaces 2019, 11, 42964-42974. [CrossRef]

194. Huang, S.; Gu, J.; Ye, J.; Fang, B.; Wan, S.; Wang, C.; Ashraf, U.; Li, Q.; Wang, X.; Shao, L.; et al. Benzoxazine monomer derived carbon dots as a broad-spectrum agent to block viral infectivity. J. Colloid Interface Sci. 2019, 542, 198-206. [CrossRef]

195. Tong, T.; Hu, H.; Zhou, J.; Deng, S.; Zhang, X.; Tang, W.; Fang, L.; Xiao, S.; Liang, J. Glycyrrhizic-Acid-Based Carbon Dots with High Antiviral Activity by Multisite Inhibition Mechanisms. Small 2020, 16, e1906206. [CrossRef] [PubMed]

196. Huang, H.T.; Lin, H.J.; Huang, H.J.; Huang, C.C.; Lin, J.H.; Chen, L.L. Synthesis and evaluation of polyamine carbon quantum dots (CQDs) in Litopenaeus vannamei as a therapeutic agent against WSSV. Sci. Rep. 2020, 10, 7343. [CrossRef]

197. Cheng, J.; Xu, Y.; Zhou, D.; Liu, K.; Geng, N.; Lu, J.; Liu, Y.; Liu, J. Novel carbon quantum dots can serve as an excellent adjuvant for the gp85 protein vaccine against avian leukosis virus subgroup J in chickens. Poult. Sci. 2019, 98, 5315-5320. [CrossRef]

198. Lin, C.-J.; Chang, L.; Chu, H.-W.; Lin, H.-J.; Chang, P.-C.; Wang, R.Y.L.; Unnikrishnan, B.; Mao, J.-Y.; Chen, S.-Y.; Huang, C.-C. High Amplification of the Antiviral Activity of Curcumin through Transformation into Carbon Quantum Dots. Small 2019, 15, 1902641. [CrossRef]

199. Wang, H.; Song, Z.; Gu, J.; Li, S.; Wu, Y.; Han, H. Nitrogen-Doped Carbon Quantum Dots for Preventing Biofilm Formation and Eradicating Drug-Resistant Bacteria Infection. ACS Biomater. Sci. Eng. 2019, 5, 4739-4749. [CrossRef]

200. Zhao, Y.; Shi, L.; Fang, J.; Feng, X. Bio-nanoplatforms based on carbon dots conjugating with F-substituted nano-hydroxyapatite for cellular imaging. Nanoscale 2015, 7, 20033-20041. [CrossRef]

201. Feng, T.; Ai, X.; Ong, H.; Zhao, Y. Dual-Responsive Carbon Dots for Tumor Extracellular Microenvironment Triggered Targeting and Enhanced Anticancer Drug Delivery. ACS Appl. Mater. Interfaces 2016, 8, 18732-18740. [CrossRef]

202. Karthik, S.; Saha, B.; Ghosh, S.K.; Pradeep Singh, N.D. Photoresponsive quinoline tethered fluorescent carbon dots for regulated anticancer drug delivery. Chem. Commun. 2013, 49, 10471-10473. [CrossRef] [PubMed]

203. Pierrat, P.; Wang, R.; Kereselidze, D.; Lux, M.; Didier, P.; Kichler, A.; Pons, F.; Lebeau, L. Efficient in vitro and in vivo pulmonary delivery of nucleic acid by carbon dot-based nanocarriers. Biomaterials 2015, 51, 290-302. [CrossRef]

204. Sharma, A.; Das, J. Small molecules derived carbon dots: Synthesis and applications in sensing, catalysis, imaging, and biomedicine. J. Nanobiotechnol. 2019, 17, 92. [CrossRef] [PubMed]

205. Liang, W.; Bunker, C.E.; Sun, Y.P. Carbon Dots: Zero-Dimensional Carbon Allotrope with Unique Photoinduced Redox Characteristics. ACS Omega 2020, 5, 965-971. [CrossRef] [PubMed]

206. Wu, J.; Liu, W.; Ge, J.; Zhang, H.; Wang, P. New sensing mechanisms for design of fluorescent chemosensors emerging in recent years. Chem. Soc. Rev. 2011, 40, 3483-3495. [CrossRef] [PubMed]

207. Zheng, M.; Xie, Z.; Qu, D.; Li, D.; Du, P.; Jing, X.; Sun, Z. On-off-on fluorescent carbon dot nanosensor for recognition of chromium (VI) and ascorbic acid based on the inner filter effect. ACS Appl Mater. Interfaces 2013, 5, 13242-13247. [CrossRef]

208. Wang, Y.; Wang, K.; Han, Z.; Yin, Z.; Zhou, C.; Du, F.; Zhou, S.; Chen, P.; Xie, Z. High color rendering index trichromatic white and red LEDs prepared from silane-functionalized carbon dots. J. Mater. Chem. C 2017, 5, 9629-9637. [CrossRef]

209. Wang, H.; Sun, P.; Cong, S.; Wu, J.; Gao, L.; Wang, Y.; Dai, X.; Yi, Q.; Zou, G. Nitrogen-Doped Carbon Dots for "green” Quantum Dot Solar Cells. Nanoscale Res. Lett. 2016, 11, 27. [CrossRef]

210. Paulo-Mirasol, S.; Martinez-Ferrero, E.; Palomares, E. Direct white light emission from carbon nanodots (C-dots) in solution processed light emitting diodes. Nanoscale 2019, 11, 11315-11321. [CrossRef] 
211. Wang, F.; Pang, S.; Wang, L.; Li, Q.; Kreiter, M.; Liu, C.-Y. One-Step Synthesis of Highly Luminescent Carbon Dots in Noncoordinating Solvents. Chem. Mater. 2010, 22, 4528-4530. [CrossRef]

212. Zdrazil, L.; Kalytchuk, S.; Hola, K.; Petr, M.; Zmeskal, O.; Kment, S.; Rogach, A.L.; Zboril, R. A carbon dot-based tandem luminescent solar concentrator. Nanoscale 2020, 12, 6664-6672. [CrossRef]

213. Rodriguez-Padron, D.; Luque, R.; Munoz-Batista, M.J. Waste-derived Materials: Opportunities in Photocatalysis. Top. Curr. Chem. 2019, 378, 3. [CrossRef]

214. Nekoueian, K.; Amiri, M.; Sillanpaa, M.; Marken, F.; Boukherroub, R.; Szunerits, S. Carbon-based quantum particles: An electroanalytical and biomedical perspective. Chem. Soc. Rev. 2019, 48, 4281-4316. [CrossRef]

215. Cui, F.; Ye, Y.; Ping, J.; Sun, X. Carbon dots: Current advances in pathogenic bacteria monitoring and prospect applications. Biosens. Bioelectron. 2020, 156, 112085. [CrossRef]

216. Dong, X.; Moyer, M.M.; Yang, F.; Sun, Y.P.; Yang, L. Carbon Dots' Antiviral Functions Against Noroviruses. Sci. Rep. 2017, 7, 519. [CrossRef] [PubMed]

217. Dong, X.; Liang, W.; Meziani, M.J.; Sun, Y.P.; Yang, L. Carbon Dots as Potent Antimicrobial Agents. Theranostics 2020, 10, 671-686. [CrossRef] [PubMed]

218. Rahmati, M.; Mozafari, M. Biological Response to Carbon-Family Nanomaterials: Interactions at the Nano-Bio Interface. Front. Bioeng. Biotechnol. 2019, 7, 4. [CrossRef]

219. Bhattacharya, K.; Mukherjee, S.P.; Gallud, A.; Burkert, S.C.; Bistarelli, S.; Bellucci, S.; Bottini, M.; Star, A.; Fadeel, B. Biological interactions of carbon-based nanomaterials: From coronation to degradation. Nanomed. Nanotechnol. Biol. Med. 2016, 12, 333-351. [CrossRef]

220. Singh, V.; Kashyap, S.; Yadav, U.; Srivastava, A.; Singh, A.V.; Singh, R.K.; Singh, S.K.; Saxena, P.S. Nitrogen doped carbon quantum dots demonstrate no toxicity under in vitro conditions in a cervical cell line and in vivo in Swiss albino mice. Toxicol. Res. 2019, 8 , 395-406. [CrossRef] [PubMed]

221. Liang, C.Y.; Pan, J.; Bai, A.M.; Hu, Y.J. Insights into the interaction of human serum albumin and carbon dots: Hydrothermal synthesis and biophysical study. Int. J. Biol. Macromol. 2020, 149, 1118-1129. [CrossRef]

222. Yan, G.H.; Song, Z.M.; Liu, Y.Y.; Su, Q.; Liang, W.; Cao, A.; Sun, Y.P.; Wang, H. Effects of carbon dots surface functionalities on cellular behaviors-Mechanistic exploration for opportunities in manipulating uptake and translocation. Colloids Surf. B Biointerfaces 2019, 181, 48-57. [CrossRef]

223. Kaksonen, M.; Roux, A. Mechanisms of clathrin-mediated endocytosis. Nat. Rev. Mol. Cell Biol. 2018, 19, 313-326. [CrossRef]

224. Kumari, S.; Mg, S.; Mayor, S. Endocytosis unplugged: Multiple ways to enter the cell. Cell Res. 2010, 20, 256-275. [CrossRef]

225. Srivastava, I.; Sar, D.; Mukherjee, P.; Schwartz-Duval, A.S.; Huang, Z.; Jaramillo, C.; Civantos, A.; Tripathi, I.; Allain, J.P.; Bhargava, R.; et al. Enzyme-catalysed biodegradation of carbon dots follows sequential oxidation in a time dependent manner. Nanoscale 2019, 11, 8226-8236. [CrossRef] [PubMed] 